\title{
Cytospora (Diaporthales) in China
}

\author{
X.L. Fan', J.D.P. Bezerra ${ }^{2}$, C.M. Tian ${ }^{1}$, P.W. Crous $^{3}$
}

Key words

canker disease

new taxa

plant pathogen

systematics

taxonomy

Valsa

\begin{abstract}
Members of the genus Cytospora are often reported as endophytes, saprobes or phytopathogens, primarily causing canker diseases of woody host plants. They occur on a wide range of hosts and have a worldwide distribution. Although several species have in the past been reported from China, the vast majority are not known from culture or DNA phylogeny. The primary aim of the present study was thus to clarify the taxonomy and phylogeny of a large collection of Cytospora species associated with diverse hosts in China. Cytospora spp. were collected in northeast, northwest, north and southwest China, indicating that the cold and dry environments favour these fungi. In this paper, we provide an assessment of 52 Cytospora spp. in China, focussing on 40 species represented by 88 isolates from 28 host genera. Based on a combination of morphology and a six-locus phylogeny (ITS, LSU, act1, rpb2, tef1- $\alpha$ and tub2), 13 new species and one new combination are introduced. The majority of the species investigated here appear to be host-specific, although further collections and pathogenicity studies will be required to confirm this conclusion.
\end{abstract}

Article info Received: 6 December 2018; Accepted: 15 March 2019; Published: 18 June 2019.

\section{INTRODUCTION}

Members of Cytospora are cosmopolitan in distribution and have often been regarded as phytopathogens, endophytes or saprobes occurring on a broad host range. Several species have been reported as pathogens causing severe branch or trunk disease on monocotyledonous, dicotyledonous and gymnosperm hosts (e.g., Anacardiaceae, Elaeagnaceae, Fabaceae, Juglandaceae, Myrtaceae, Rosaceae, Salicaceae, Ulmaceae) (Adams et al. 2005, 2006, Mehrabi et al. 2011, Fan et al. 2014a, b, 2015a, b, Zhang et al. 2014, Jami et al. 2018).

As plant pathogens, Cytospora species are primarily associated with canker diseases, although other maladies have also been reported such as root rot of Chinese jujube and collar rot of pomegranate (Du et al. 2013, Palavouzis et al. 2015). Cytospora canker symptoms include elongate, slightly sunken and discoloured areas in the bark, which often splits along the canker margin. Symptoms vary with host species and stage of disease development (Fig. 1). Diseased inner-bark and the bark above the infected cambium may appear sunken and yellow, brown, reddish brown, grey or black, becoming watery and odorous as the tissues deteriorate. Wood below the cambium is stained brown. Histopathologically, the rapid colonisation of the cortex and phloem are via wide intercellular hyphae, while the cell contents are digested by narrower intracellular hyphae following the forming of chambers (Fig. 2). Later, these fungi quickly girdle and kill branches and twigs, forming several prominent black sporocarps (Fig. 1). Species of Cytospora have a single or labyrinthine of locules (and/or diaporthaleanlike perithecia), filamentous conidiophores (and/or clavate to elongate obovoid asci) and allantoid, hyaline conidia (and/or ascospores) (Spielman 1983, 1985, Adams et al. 2005). Under

\footnotetext{
1 The Key Laboratory for Silviculture and Conservation of the Ministry of Education, Beijing Forestry University, Beijing 100083, China; corresponding author e-mail: chengmt@bju.edu.cn.

2 Departamento de Micologia Prof. Chaves Batista, Universidade Federal de Pernambuco, Av. Prof. Moraes Rego, s/n, Centro de Biociências, Cidade Universitária, CEP: 50670-901, Recife, PE, Brazil.

${ }^{3}$ Westerdijk Fungal Biodiversity Institute, Uppsalalaan 8, 3584 CT Utrecht, The Netherlands.
}

moist conditions, the conidia emerge from the fructifications in the form of yellow, orange to red gelatinous tendrils (Fig. 1).

\section{Classification and history}

The ascomycete order Diaporthales (Sordariomycetes) is well-known to contain fungal phytopathogens, endophytes and saprobes, with wide distributions and broad host ranges (Castlebury et al. 2002, Rossman et al. 2007, Fan et al. 2018). Members of this order cause various serious diseases, e.g., chestnut blight disease caused by Cryphonectria parasitica (Gryzenhout et al. 2006); stem-end rot of citrus fruits infected by Diaporthe citri (Huang et al. 2013); poplar and willow canker disease caused by Cytospora chrysosperma (Fan et al. 2014b), birch canker and dieback caused by Melanconis stilbostoma (Fan et al. 2016), leading to severe ecological and economic losses worldwide. The Diaporthales is characterised by forming brown to black perithecial ascomata immersed in stromata or substrata, and a diaporthalean-type centrum development, i.e., lacking true paraphyses, and having unitunicate asci that commonly float free at maturity, often with a refractive ring at the apex (Barr 1978, Castlebury et al. 2002, Rossman et al. 2007, Voglmayr et al. 2012, Fan et al. 2018). Recent studies accepted 30 families in Diaporthales, of which Cytosporaceae contains more than 600 species epithets (Senanayake et al. 2017, 2018, Fan et al. 2018, Crous et al. 2019, Guterres et al. 2019, Xavier et al. 2019).

Cytosporaceae was introduced by Fries (1825) but later placed in synonymy under Valsaceae (1861), only to be resurrected again as family name for this complex (Cytosporaceae; Rossman et al. 2015). Nitschke (1867) published the first important study of the family including four genera, i.e., Anthostoma, Diaporthe, Thyridium and Valsa (= Cytospora). Von Höhnel (1918) believed the subfamily Valseen comprised six allantoidspored genera, i.e., Leucostoma, Peroneutypa, Scoptria, Valsa, Valsella and Valseutypella. Nannfeldt (1932) elevated Valseen to ordinal level as Valsales, but Gilman et al. (1957) considered these taxa as the subfamily Valseae within Diaporthaceae, comprising Endothia, Fenestella, Valsa, Valsaria and Valsella, a decision which was adopted by Dennis (1968) and Kobayashi

○ 2019-2020 Naturalis Biodiversity Center \& Westerdijk Fungal Biodiversity Institute

You are free to share - to copy, distribute and transmit the work, under the following conditions:

$\begin{array}{ll}\text { Attribution: } & \text { You must attribute the work in the manner specified by the author or licensor (but not in any way that suggests that they endorse you or your use of the work) } \\ \text { Non-commercial: } & \text { You may not use this work for commercial purposes. }\end{array}$

Non-commercia:

No derivative works: You may not alter, transform, or build upon this work

For any reuse or distribution, you must make clear to others the license terms of this work, which can be found at http://creativecommons.org/licenses/by-nc-nd/3.0/legalcode. Any of the above conditions can be waived if you get permission from the copyright holder. Nothing in this license impairs or restricts the author's moral rights. 

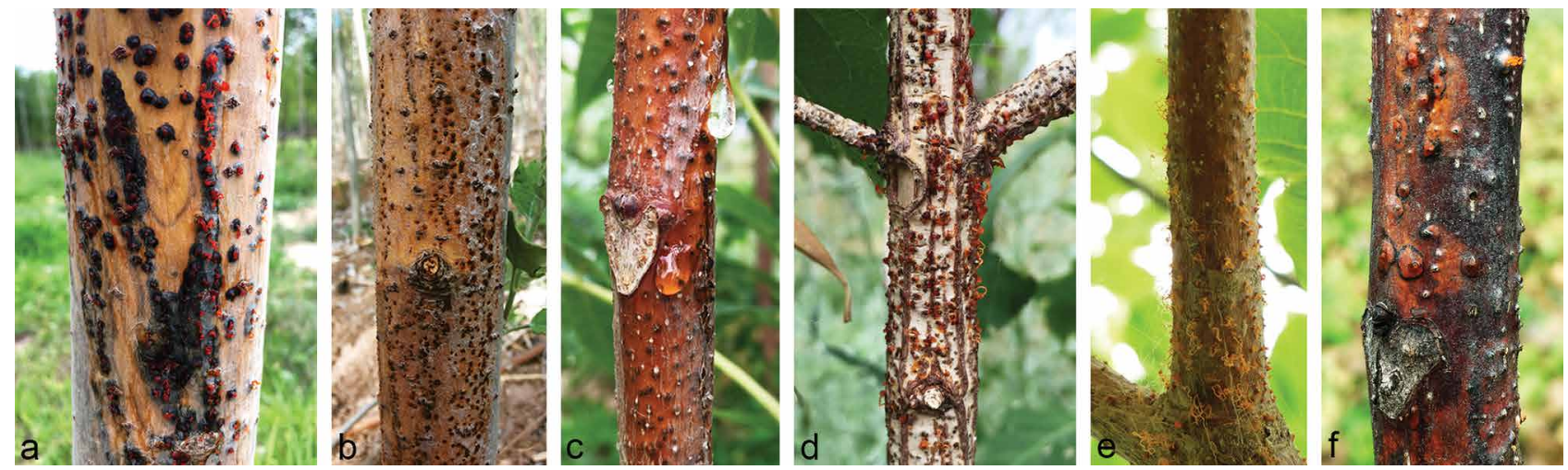

Fig. 1 Disease symptoms associated with Cytospora spp. a-b. Populus alba subsp. pyramidalis; c. Ailanthus altissima; d. Euonymus maackii; e-f. Juglans regia.
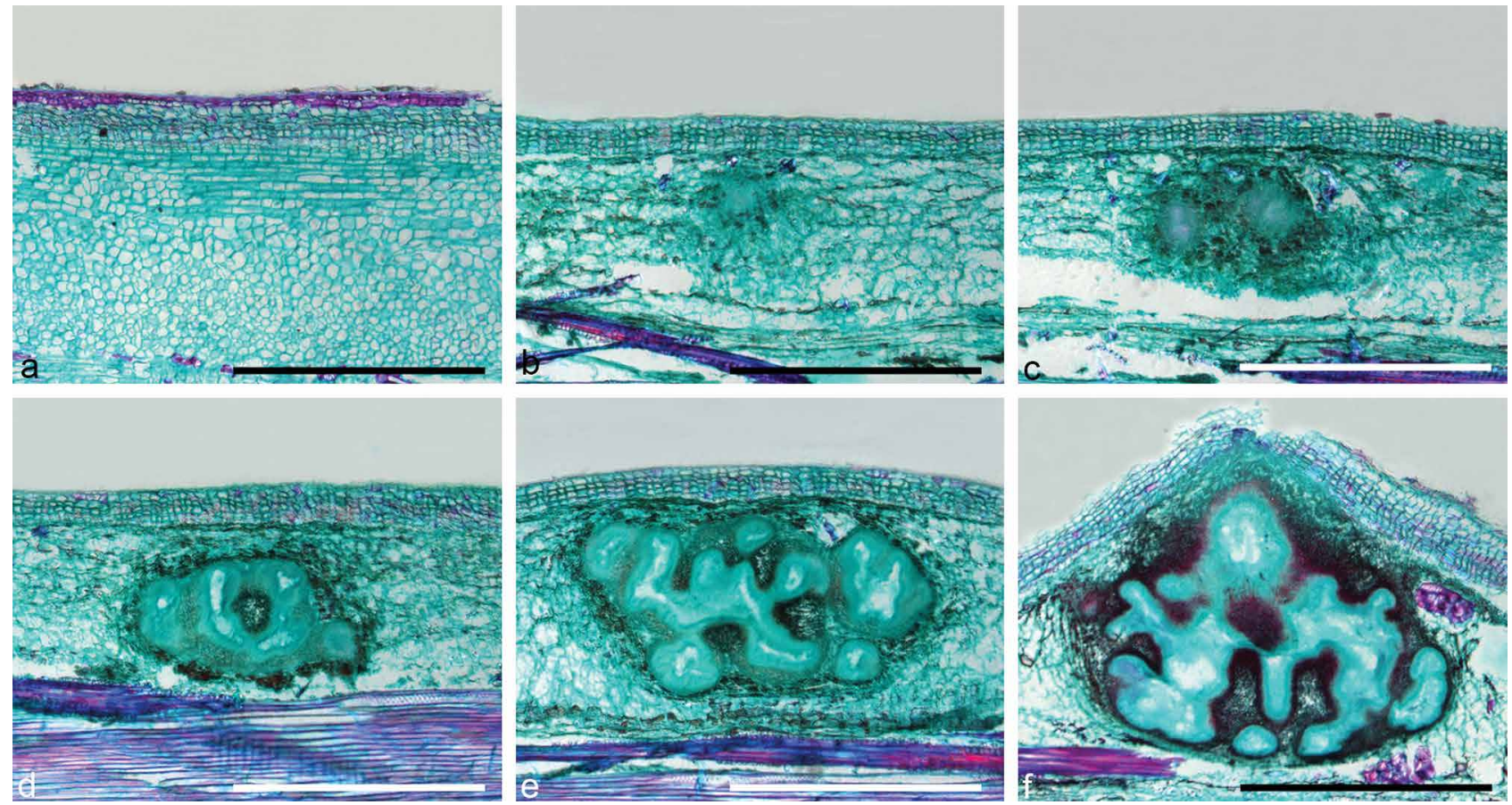

Fig. 2 Infection process of Cytospora chrysosperma on Populus alba subsp. pyramidalis. a. Uninfected tissues; b. initial stage of pycnidial development (aggregation of mycelial cells in the cortex tissues) ( $6 \mathrm{~d}$ ); c. formation of locules in the centre of pycnidial primordium (10 d); $d$-e. combination of adjacent locules (12 d); f. mycelial mass above locules rupturing the cuticle and forming an ostiole through the apical rupture $(15 \mathrm{~d})$. - Scale bars $=0.5 \mathrm{~mm}$.

(1970). Wehmeyer (1975) separated Valsaceae from Diaporthaceae with Leucostoma, Glomerella, Scoptria, Valsa and Valsella. Dennis (1978) merged almost all allantoid-spored genera (including Leucostoma, Valsa and Valsella) into the Diatrypaceae. Barr (1978) recognised the connection of Valsaceae and Diaporthaceae based on the characters of ascomata, and treated Diaporthaceae as synonym of Valsaceae, including 15 genera (Amphiporthe, Apioplagiostoma, Clypeoporthella, Cryphonectria, Cryptodiaporthe, Diaporthe, Hypospilina, Leucostoma, Linospora, Ophiovalsa, Plagiosphaera, Plagiostoma, Pleuroceras, Valsa and Valsella). Most genera from Barr's system have since been separated in different families in Diaporthales (Amphiporthe, Apioplagiostoma, Cryptodiaporthe (now Plagiostoma), Plagiostoma, Pleuroceras in Gnomoniaceae; Cryphonectria, Endothia in Cryphonectriaceae; Clypeoporthella (now Diaporthe), Diaporthe in Diaporthaceae; Linospora, Ophiovalsa (now Cryptosporella) in Gnomoniaceae), and some genera are not classified in Diaporthales (Anthostoma, Fenestella, Glomerella (now Colletotrichum), Peroneutypa, Scoptria (now Eutypella), Thyridium and Valsaria) or remain unresolved (Hypospilina, Plagiosphaera) (Senanayake et al. 2017, 2018, Fan et al. 2018). Castlebury et al. (2002) suggested three genera (Leucostoma, Valsa and Valsella) in Valsaceae based on an LSU phylogeny, while Adams et al. (2005) treated Cytospora and Valsa in this family, regarding the sexual genera (Leucocytospora, Leucostoma, Valsella and Valseutypella) as synonyms of Valsa. Based on the one fungus = one name initiative (Wingfield et al. 2012), Fan et al. (2015a, b) and Rossman et al. (2015) recommended to use Cytospora, the oldest name having priority over Valsa, and Cytosporaceae having priority over Valsaceae. Senanayake et al. (2017) regarded Cytospora, Pachytrype, Paravalsa, Waydora and Xenotypa as genera of Cytosporaceae.

Cytospora was introduced by Ehrenberg (1818) with four species (C. betulina, C. epimyces, C. resinae and C. ribis). Fries (1823) described 18 Cytospora species, but he considered it as Cytispora (orthographic variant). Saccardo (1884) revised the name to Cytospora and recorded 144 species. Gvritishvili (1982) and Spielman $(1983,1985)$ regarded the morphologically similar genera Cytophoma, Cytospora, Cytosporopsis, Lamyella, Leucocytospora and Torsellia as six sections based on the structure of their conidiomatal locules. The first molecular phylogeny of Cytospora was inferred from ITS sequences which suggested six groups, with a new species C. parapersoonii 
(Leucostoma parapersoonii) (Adams et al. 2002). Adams et al. (2005) formally treated these genera as synonyms of Cytospora with eight sections, and described 28 Cytospora species from Eucalyptus based on ITS phylogeny and morphology. Several recent papers have subsequently described new species of Cytospora using multi-locus DNA sequence data (Wang et al. 2013, Zhang et al. 2014, Fan et al. 2014a, b, 2015a, b, Yang et al. 2015, Norphanphoun et al. 2017, Senanayake et al. 2017, 2018, Jami et al. 2018, Zhu et al. 2018).

\section{Nomenclature of Cytospora and associated sexual morphs}

Cytospora has priority over several sexual genera in the previous dual-nomenclature system, i.e., Leucocytospora, Leucostoma, Valsa, Valsella and Valseutypella (Adams et al. 2005, Fan et al. 2015a, b, Rossman et al. 2015). The type species of Cytospora, C. chrysosperma (sexual morph Valsa sordida), is the most common species causing Cytospora cankers on Salicaceae, especially in China (Fan et al. 2014b), having a remarkably wide host range. The genus Valsa, typified by V. ambiens, is commonly associated with its Cytospora asexual morph (Spielman 1985, Hayova \& Minter 1998). The type species of Leucostoma, L. massarianum, clustered within the genus Cytospora, and was regarded as synonym (Adams et al. 2002, 2005). Adams et al. (2005) also listed Leucocytospora (based on L. corni) as a synonym of Cytospora. Leucostoma and Leucocytospora were previously distinguished from Valsa by an obvious dark conceptacle delimiting the stroma from host tissue (Adams et al. 2005). The genus Valsella (based on $V$. salicis) is characterised by a leucostoma-like conceptacle, and more than eight ascospores per ascus. This species was considered as a synonym of Cytospora fertilis and grouped with other Cytospora species (Castlebury et al. 2002). The type species of Valseutypella (based on V. tristicha), was recognised by the presence of a parenchymatous stroma surrounding its perithecia (Fries 1823, Saccardo 1884, Spielman 1985, Adams et al. 2005). Adams et al. (2005) regarded these genera as synonyms of Valsa, which are now classified under the oldest name, Cytospora (Fan et al. 2015a, b, Rossman et al. 2015).

\section{Identification and species numbers}

In the past, species identification in Cytospora was largely based on host affiliation, with morphological descriptions. Several species of Cytospora associated with canker diseases have been systematically studied using a geography- or hostcentred strategy. Adams et al. (2005) combined morphology and phylogeny using ITS sequence data to describe 28 species of Cytospora from Eucalyptus, of which 11 species were new to science. Adams et al. (2006) described 14 additional species from South Africa using the same methodology. Fotouhifar et al. (2010) identified 12 species from Iran using morphology and ITS phylogeny. Mehrabi et al. (2011) used morphology to identify six species of Cytospora from apple trees in Iran and also described their sexual morphs. Although more than 600 Cytospora species epithets have been listed in Index Fungorum (http://www. indexfungorum.org/; 2018), and 110 were recognised in Kirk et al. (2008), details pertaining to ex-type strains of Cytospora are available for only a few species. Donk (1964) selected C. chrysosperma as the lectotype species, but to date there are no living cultures linked to the type specimen.

In China, previous Cytospora records were based on old literature, generally lacking cultures (Teng 1963, Tai 1979, Wei 1979, Zhuang 2005). Recent identifications were performed mainly according to the ITS rDNA gene (Wang et al. 2013, Zhang et al. 2014, Fan et al. 2014a, b, 2015a, b, Yang et al. 2015, Zhu et al. 2018). To facilitate species recognition of Cytospora in China, a phylogenetic backbone is urgently required. The objectives of the present study were: i. to clarify species boundaries among Cytospora isolates from various host genera distributed over 12 provinces in China;

ii. to provide a multi-gene phylogeny for the genus Cytospora based on a large set of freshly collected specimens in China;

iii. to link Chinese Cytospora names to recent collections based on epitypification; and

iv. to elucidate host specificity and the relationship between Cytospora species and their respective host plants.

\section{MATERIALS AND METHODS}

\section{Isolates}

Fresh specimens exhibiting Cytospora canker disease symptoms were collected from infected branches or twigs of 28 host genera (40 species) during collecting trips in 12 Provinces in China (Table 1). A total of 88 isolates were established by removing a mucoid spore mass from conidiomata and/or ascomata, spreading the suspension on the surface of $1.8 \%$ potato dextrose agar (PDA) in a Petri dish, and incubating at $25^{\circ} \mathrm{C}$ for up to $24 \mathrm{~h}$. Single germinating conidia were transferred onto fresh PDA plates. Specimens are deposited in the Museum of the Beijing Forestry University (BJFC) and the working Collection of X.L. Fan (CF) housed at the Beijing Forestry University. Axenic cultures are maintained in the China Forestry Culture Collection Centre (CFCC).

\section{DNA isolation, amplification and sequencing}

Genomic DNA was extracted using the Wizard $\AA$ Genomic DNA Purification Kit (Promega, Madiso, WI, USA) following the manufacturer's instructions, from fungal mycelium growing on PDA. The internal transcribed spacer (ITS) region was amplified with the primers ITS1 and ITS4 (White et al. 1990), the nuclear ribosomal large subunit (LSU) region with the primers LROR and LR7 (Vilgalys \& Hester 1990), the partial actin (act1) region was amplified using primers ACT512F and ACT783R (Carbone \& Kohn 1999), the partial RNA polymerase II subunit (rpb2) region with primers RPB2-5F and fRPB2-7cR (Liu et al. 1999), the partial translation elongation factor 1-alpha (tef1- $\alpha$ ) gene with the primers EF1-728F and EF1-986R (Carbone \& Kohn 1999) and the partial beta-tubulin (tub2) gene was amplified using primers Bt2a and Bt2b (Glass \& Donaldson 1995). The PCR mixture for all genes consisted of $1 \mu \mathrm{L}$ genomic DNA, $3 \mathrm{mM}$ $\mathrm{MgCl}_{2}, 20 \mu \mathrm{M}$ of each dNTP, $0.2 \mu \mathrm{M}$ of each primer and $0.25 \mathrm{U}$ rTAQ DNA polymerase (TAKARA). Conditions for PCR of ITS, LSU and tef1- $\alpha$ genes constituted an initial denaturation step of 2 min at $95^{\circ} \mathrm{C}$, followed by 35 cycles of $30 \mathrm{~s}$ at $95^{\circ} \mathrm{C}, 30 \mathrm{~s}$ at $48{ }^{\circ} \mathrm{C}$ and $1 \mathrm{~min}$ at $72^{\circ} \mathrm{C}$, and a final denaturation step of 8 $\min$ at $72^{\circ} \mathrm{C}$. Conditions for act 1 and tub2 genes constituted an initial denaturation step of $2 \mathrm{~min}$ at $95^{\circ} \mathrm{C}$, followed by 35 cycles of $30 \mathrm{~s}$ at $95^{\circ} \mathrm{C}, 30 \mathrm{~s}$ at $55^{\circ} \mathrm{C}$ and $1 \mathrm{~min}$ at $72{ }^{\circ} \mathrm{C}$, and a final denaturation step of $8 \mathrm{~min}$ at $72^{\circ} \mathrm{C}$. For the $r p b 2$ gene, the amplification consisted of five cycles of $45 \mathrm{~s}$ at $95^{\circ} \mathrm{C}, 45 \mathrm{~s}$ at $56{ }^{\circ} \mathrm{C}$ and 2 min at $72{ }^{\circ} \mathrm{C}$, then five cycles with $53^{\circ} \mathrm{C}$ annealing temperature and 30 cycles with $50{ }^{\circ} \mathrm{C}$ annealing temperature. The PCR products were sequenced in both directions using the PCR primers and the BigDye Terminator v. 3.1 Cycle Sequencing Kit (Applied Biosystems, Foster City, CA, USA), and performed with an ABI Prism 3730XL Sequencer (Applied Biosystems) according to the instructions of manufacturer.

\section{Phylogenetic analyses}

DNA sequencing electropherograms generated by each primer combination were assembled using Seqman v. 7.1.0 in the DNASTAR Lasergene core suite software (DNASTAR Inc., 


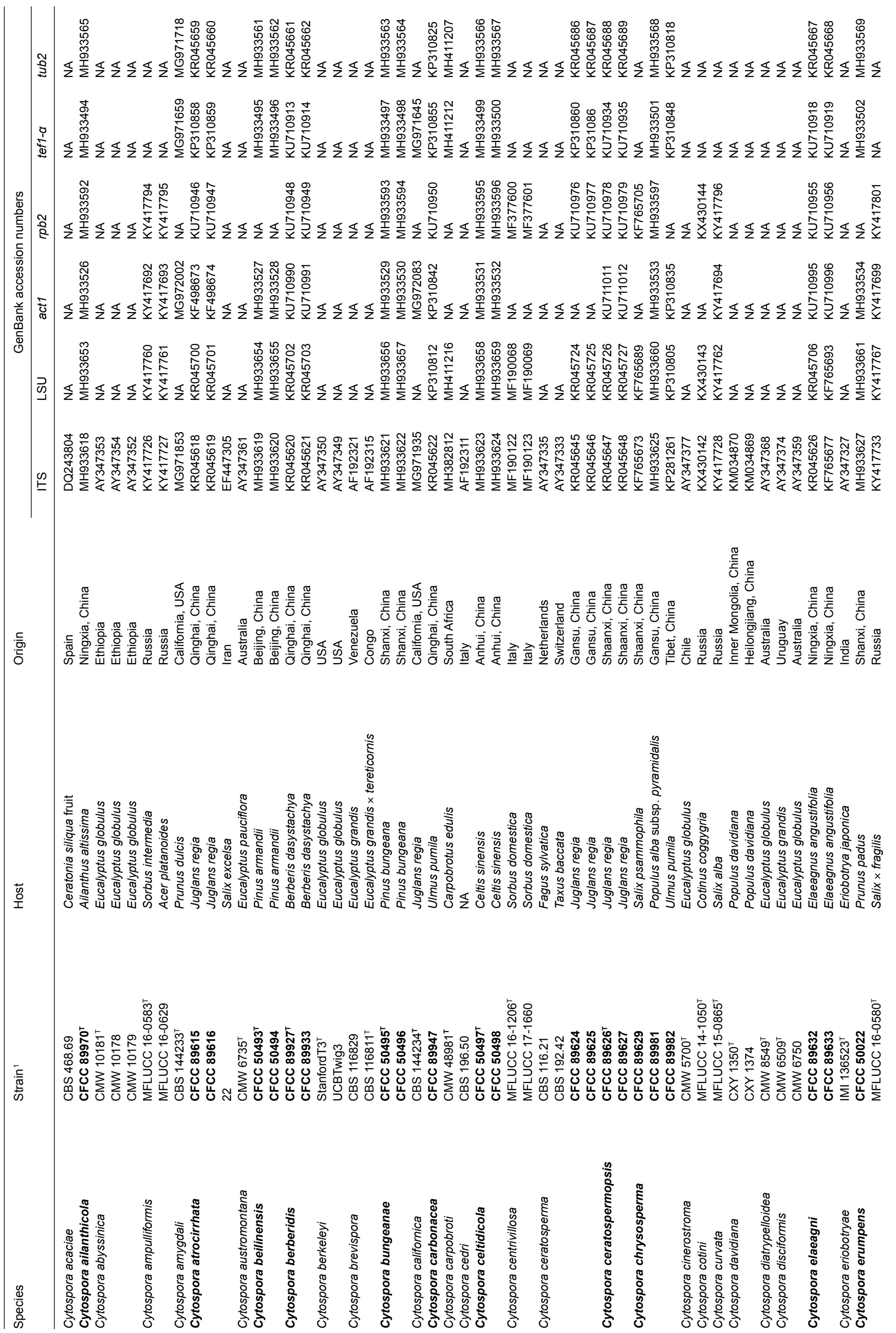




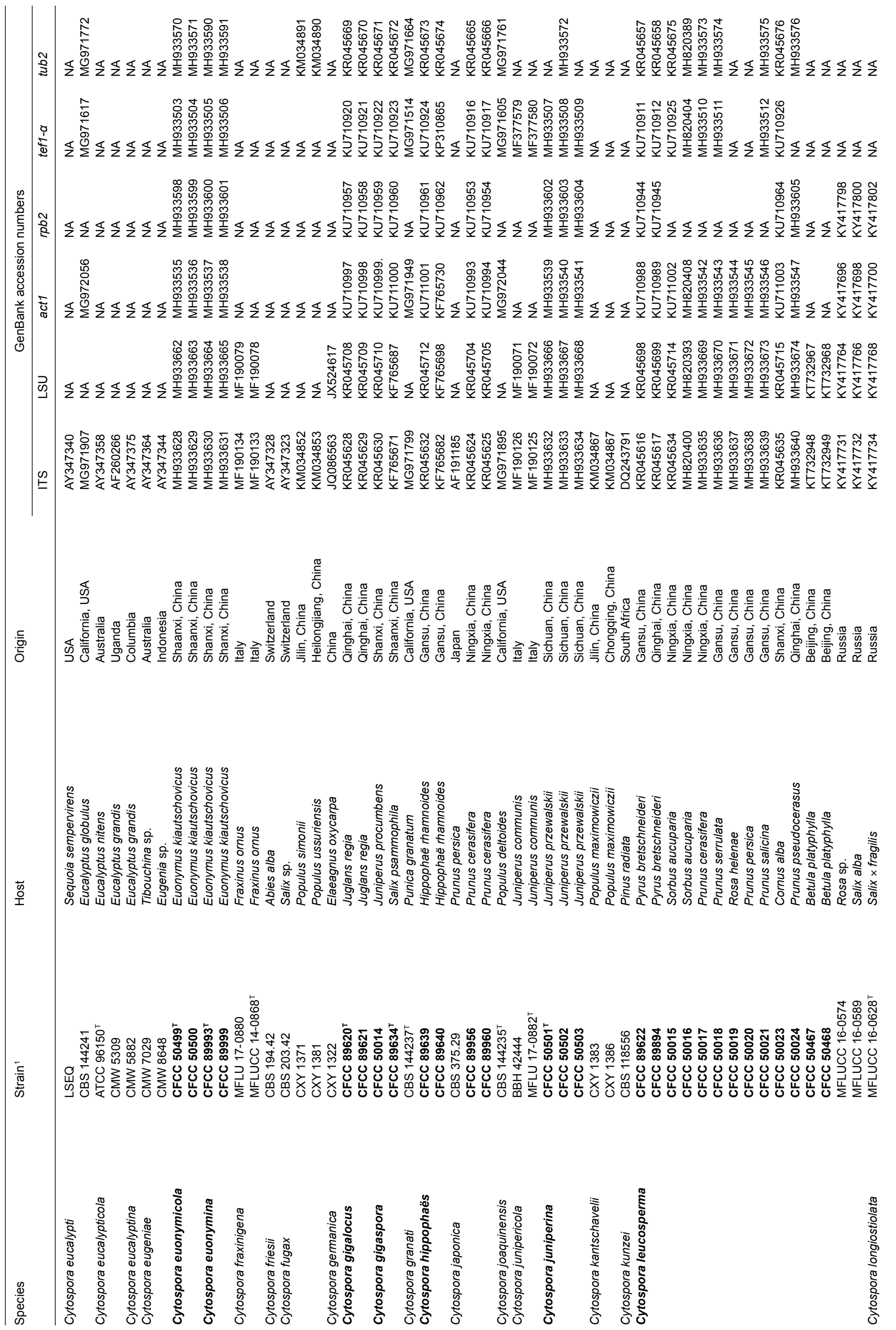




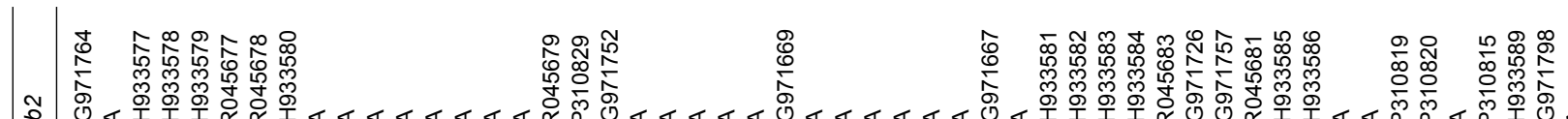

等

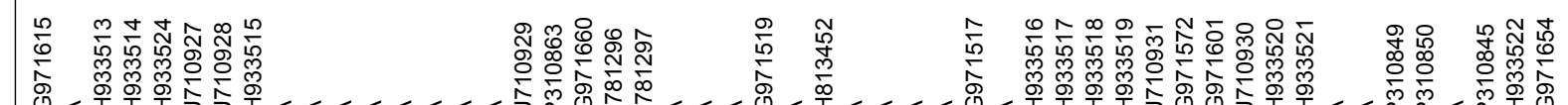

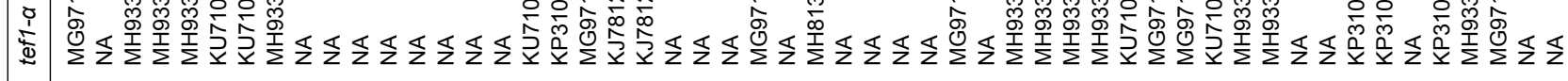

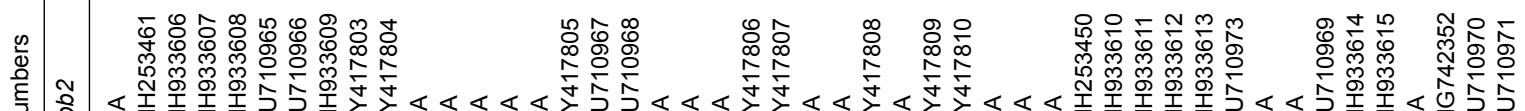

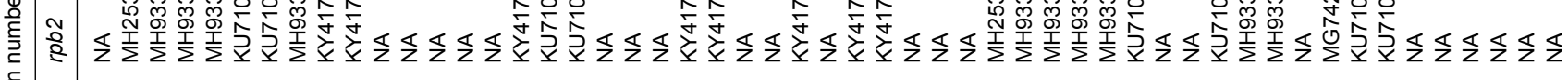

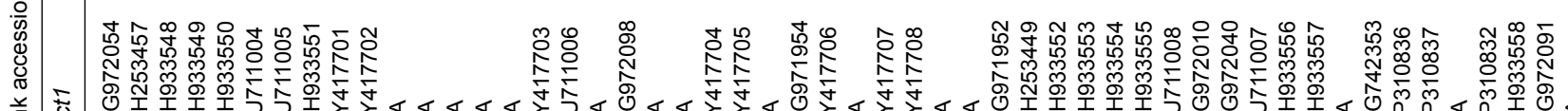

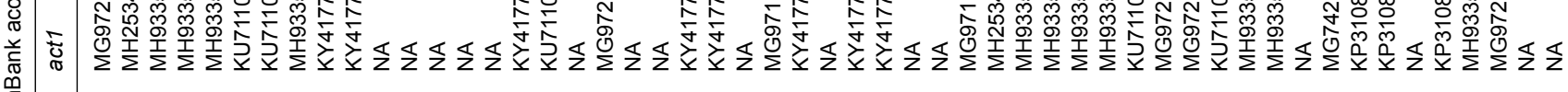
品

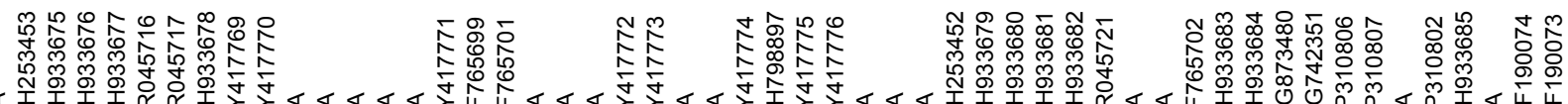

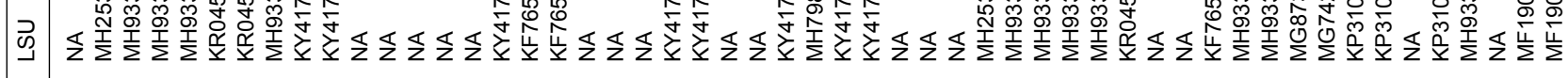

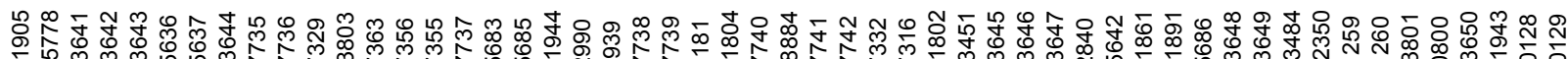

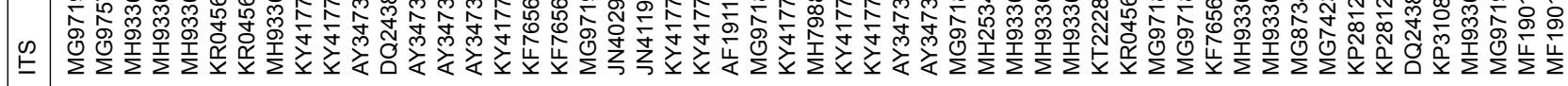

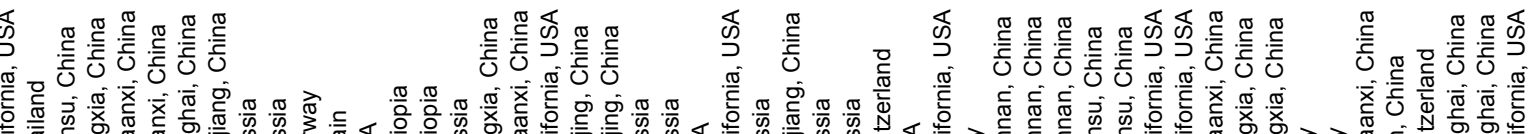

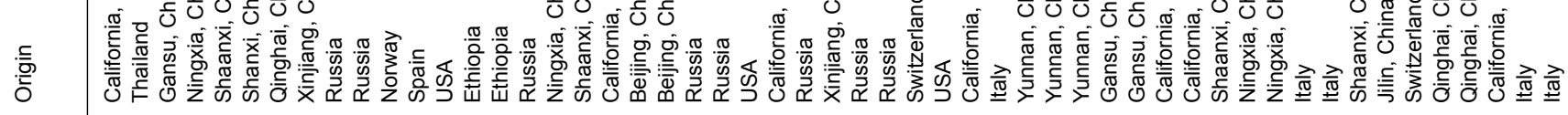

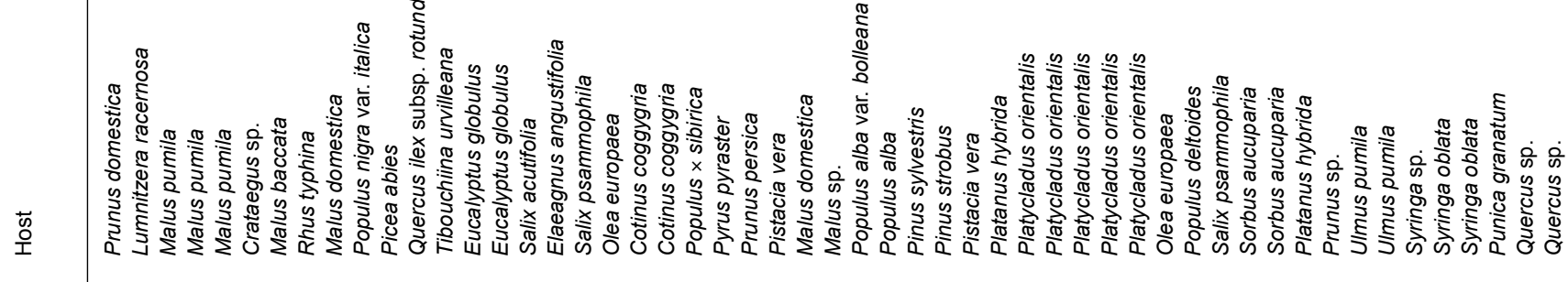

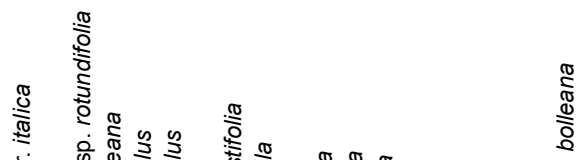

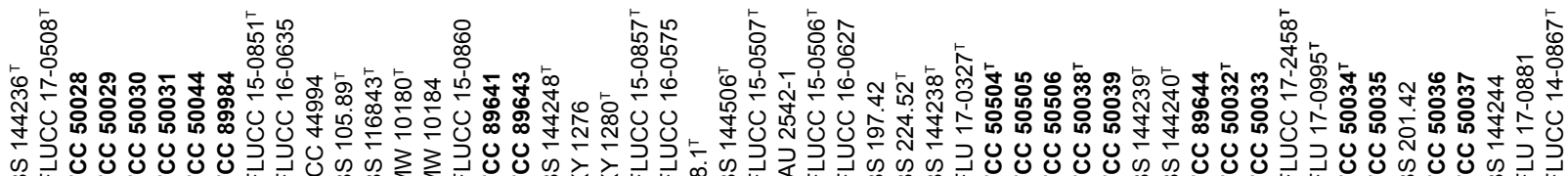

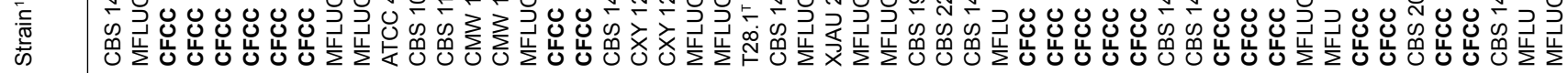




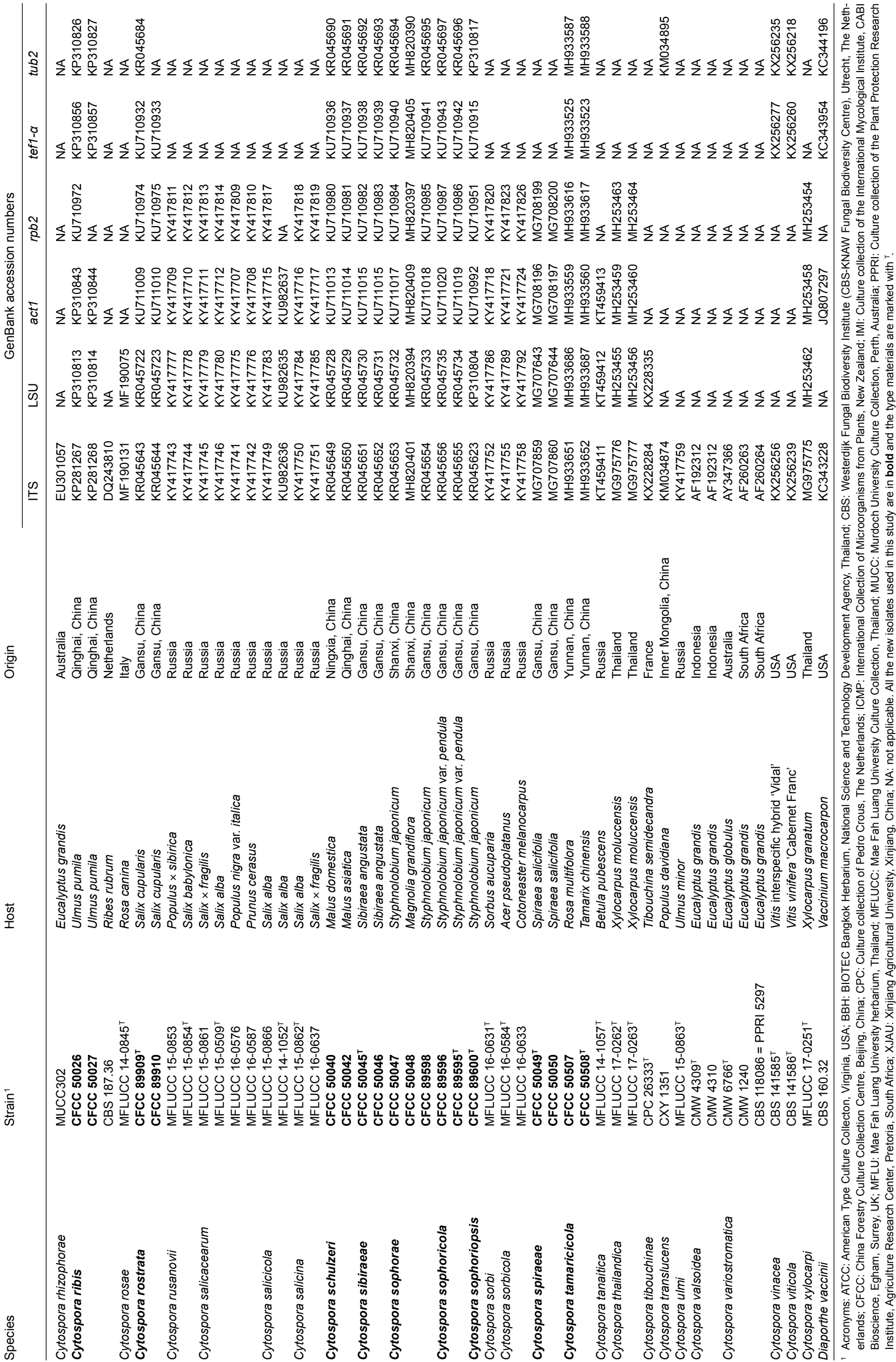




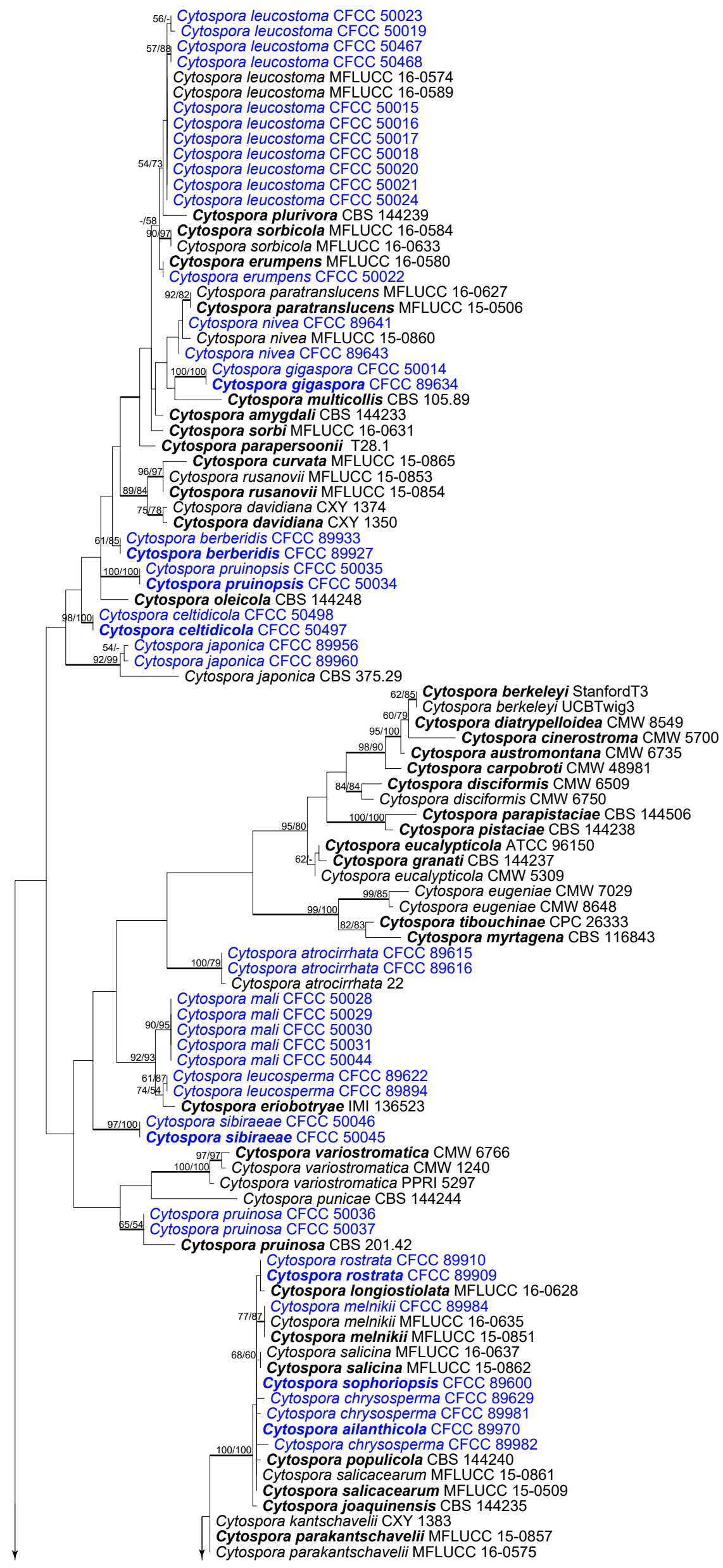

Fig. 3 Maximum parsimony phylogram of Cytospora obtained from the ITS rDNA gene matrix. MP bootstrap support values above $50 \%$ and posterior probabilities above 0.95 from $\mathrm{Bl}$ are given at the first and second position. - Scale bar $=20$ nucleotide substitutions. Ex-type strains are in bold; strains obtained in the current study in blue. 


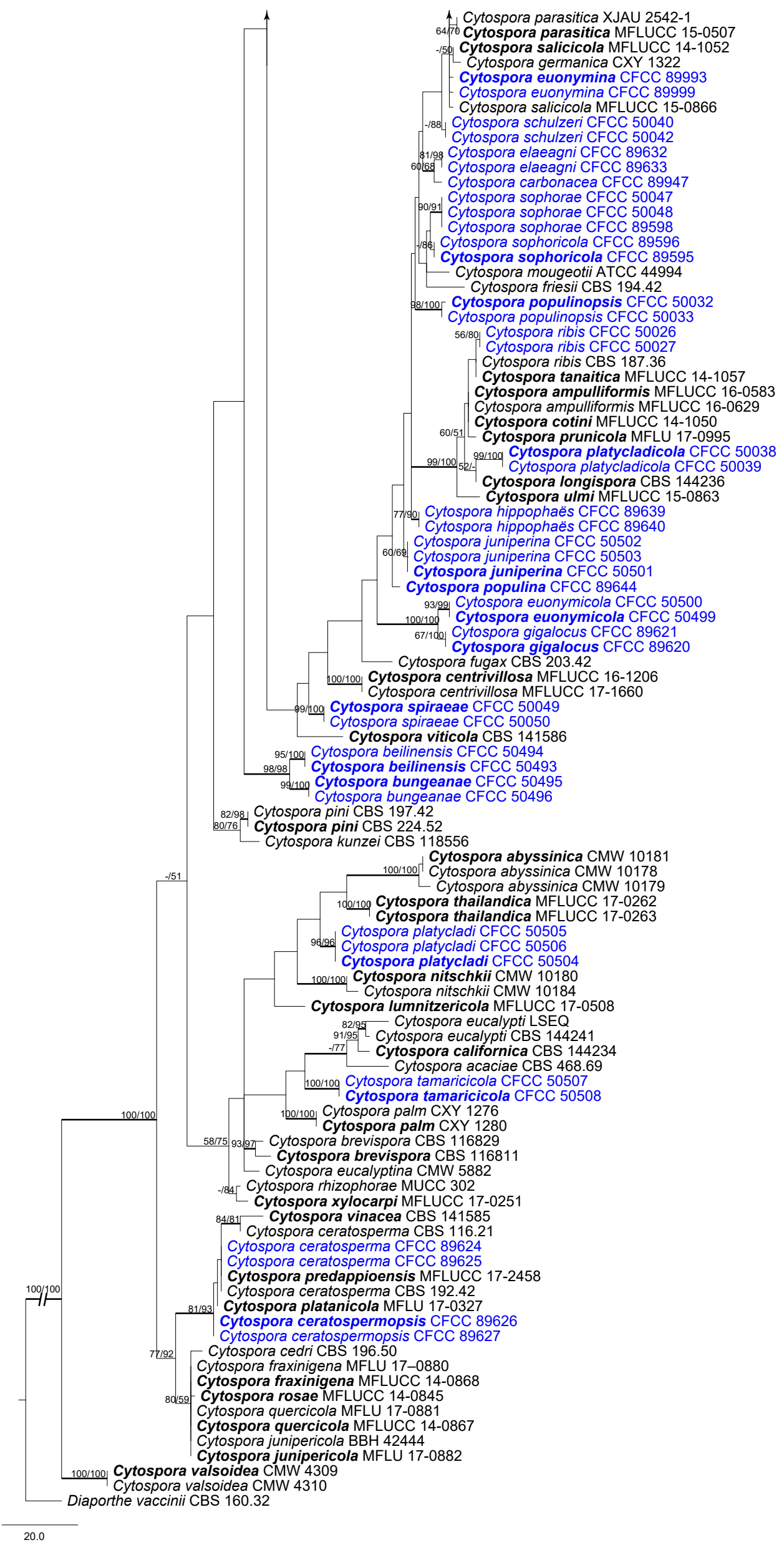

Fig. 3 (cont.) 


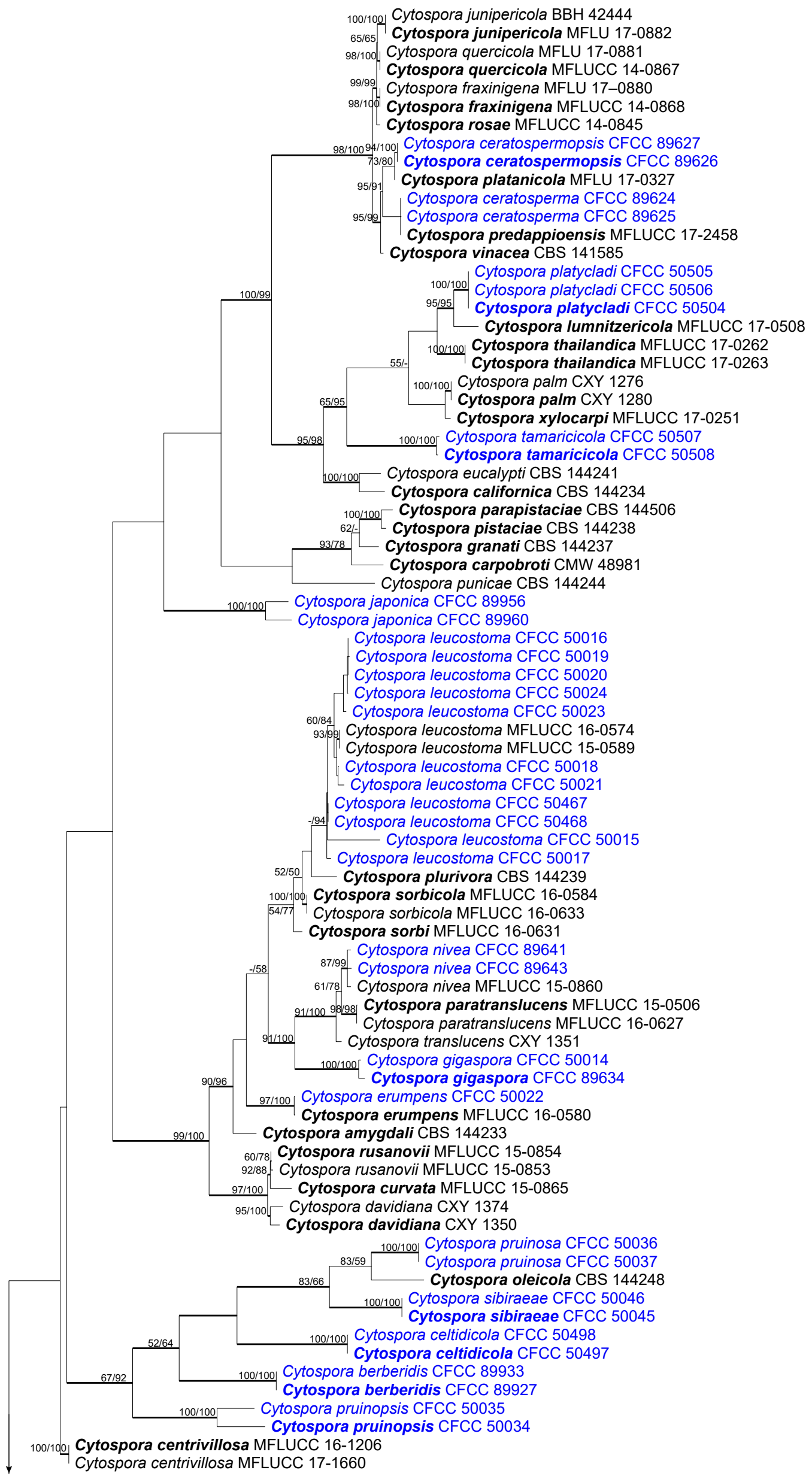

Fig. 4 Maximum parsimony phylogram of Cytospora obtained from the combined matrix of ITS, LSU, act1, rpb2, tef1- $\alpha$ and tub2 genes. MP bootstrap support values above $50 \%$ and posterior probabilities above 0.95 from BI are given at the first and second position. - Scale bar $=200$ nucleotide substitutions. Ex-type strains are in bold; strains obtained in the current study in blue. 


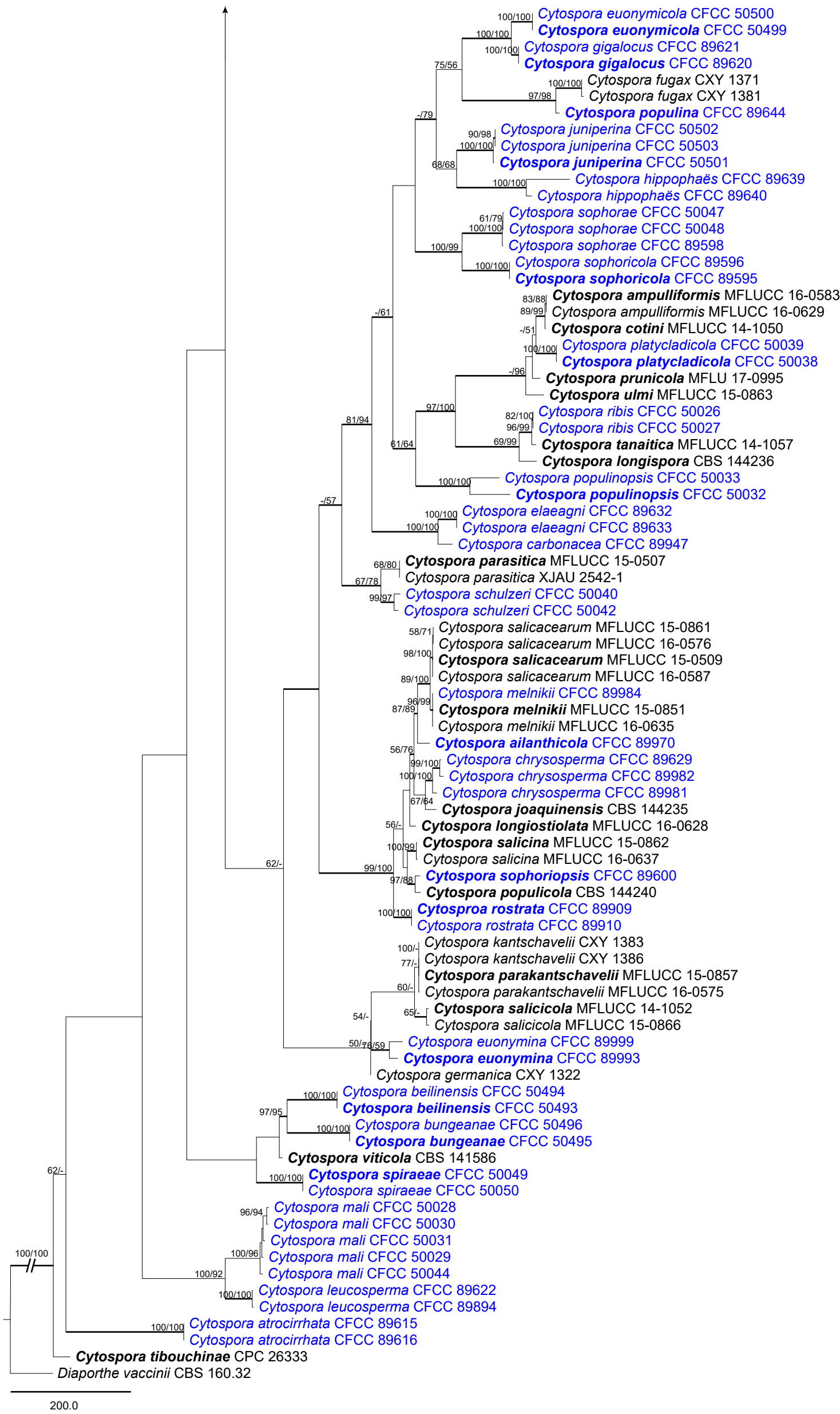

Fig. 4 (cont.) 
Madison, WI, USA). To infer a preliminary phylogenetic relationship for the new sequences, an initial alignment of the ITS rDNA sequences was performed using MAFFT v. 6 (Katoh \& Standley 2013) and edited manually using MEGA v. 6.0 (Tamura et al. 2013), and some characters were excluded from both ends of the alignments to approximate the size of our sequences to those included in the dataset. This alignment was used to infer a preliminary phylogenetic relationship for the new sequences based on Maximum Parsimony (MP), Maximum Likelihood (ML) and Bayesian Inference (BI) analyses.

The second alignment based on a combined matrix was constructed using available ITS, LSU, act1, rpb2, tef1- $\alpha$ and tub2 sequences. For individual datasets, sequences were aligned using MAFFT v. 6 and edited manually using MEGA v. 6.0, and some characters were excluded from both ends of the alignments. A partition homogeneity test (PHT) with heuristic search and 1000 homogeneity was performed using PAUP v. 4.0b10 to test the discrepancy among the ITS, LSU, act1, rpb2, tef1- $\alpha$ and tub2 sequence dataset in reconstructing phylogenetic trees. The parsimony optimality criterion was used to perform the MP analysis in PAUP v. 4.0b10. The MP analysis was conducted using a heuristic search (1000 bootstrap) (Hillis \& Bull 1993), with random sequence addition as option to stepwise-addition (1000 replicates and one tree held at each addition step), and maxtrees limited to 200 by replicate. The tree bisection and reconnection (TBR) was selected as option to the branch swapping algorithm (Swofford 2003). The branches of zero length were collapsed using the command minbrlen and all equally most parsimonious trees were saved. Other parsimony scores such as tree length ( $T L)$, consistency index $(\mathrm{Cl})$, retention index (RI) and rescaled consistency (RC) were calculated (Swofford 2003). Maximum likelihood analysis was performed by PhyML v. 3.0 with a GTR site substitution model, including a gammadistributed rate heterogeneity and a proportion of invariant sites (Guindon et al. 2010). Bayesian inference was performed using the best-fit evolutionary models for each partitioned locus estimated in MrModeltest v. 2.3 (Posada \& Crandall 1998) following the Akaike Information Criterion (AIC), with a Markov Chain Monte Carlo (MCMC) algorithm in MrBayes v. 3.1.2 (Ronquist \& Huelsenbeck 2003). Two MCMC chains were run from random trees for $10 \mathrm{M}$ generations and stopped when average standard deviation of split frequencies fell below 0.01 . Trees were saved each 1000 generations. The first $25 \%$ of trees were discarded as the burn-in phase of each analysis, and the posterior probabilities (BPP) were calculated to assess the remaining trees (Rannala \& Yang 1996). The branch support from MP and ML analyses were evaluated with a bootstrapping (BS) method of 1000 replicates (Hillis \& Bull 1993). Diaporthe vaccinii (CBS 160.32 ) was selected as outgroup in all analyses. Phylograms were shown using Figtree v. 1.3.1 (Rambaut \& Drummond 2010). Novel sequences generated in the current study were deposited in GenBank (Table 1) and the aligned matrices used for phylogenetic analyses and the resulting trees in TreeBASE (www.treebase.org; accession number: S23600).

\section{Morphology}

Descriptions of the asexual and sexual morphs are based on host materials. The macro-morphological photographs were captured using a Leica dissecting microscope (M205 FA), including size and arrangement of stromata; presence or absence of special structures such as conceptacle and central column; number and diameter of ostioles per ectostromatic disc; shape and size of discs; number of locules. Micro-morphological observations include size and shape of conidiophores and conidia (asci and ascospores) determined under a Leica compound microscope (DM 2500) with differential interference contrast (DIC). Stromata were mounted in sterile water, more than 20 stromata were sectioned, and 50 measurements determined per structure, with extremes of conidial measurements given in parentheses. Colony diameters were measured and the colony colours described after 3 and $30 \mathrm{~d}$ according to the colour charts of Rayner (1970). Adobe Photoshop CS v. 5 was used for the manual editing. Nomenclatural novelties were deposited in MycoBank (Crous et al. 2004).

\section{RESULTS}

\section{Phylogenetic analyses}

The phylogenetic analysis of ITS sequence data contained 200 Cytospora ingroup strains with a total of 617 characters including gaps, of which 345 characters are constant, 69 variable characters are parsimony-uninformative and 203 characters are variable and parsimony-informative. MP analyses generated 200 parsimonious trees, one of which is presented in Fig. 3 $(\mathrm{TL}=1088, \mathrm{Cl}=0.379, \mathrm{RI}=0.853, \mathrm{RC}=0.323) . \mathrm{ML}$ and Bayesian analyses were similar to the MP tree.

The second phylogenetic analysis was performed based on a combined dataset of the available ITS, LSU, act1, rpb2, tef1- $\alpha$ and tub2 sequences. The multi-gene analyses include 162 Cytospora ingroup strains with a total of 4066 characters including gaps (661 characters for ITS, 525 for LSU, 354 for act1, 731 for $r p b 2,779$ for tef1- $\alpha$ and 1016 for tub2), of which 2277 characters are constant, 207 variable characters are parsimony-uninformative and 1582 characters are variable and parsimony-informative. Each individual alignment has the following constant characters (ITS $=432$, LSU $=426$, act1 $=199$, $r p b 2=464$, tef1 $-\alpha=402$ and tub2 $=490)$, variable characters parsimony-uninformative $(\mathrm{ITS}=61, \mathrm{LSU}=39$, act $1=24$, rpb2 $=$ 6 , tef1 $-\alpha=34$ and tub2 $=49$ ) and variable characters and parsimony-informative $($ ITS $=164, \mathrm{LSU}=56$, act $1=164$, rpb2 $=257$, tef1 $-\alpha=411$ and tub2 $=529)$. MP analysis generated six most parsimonious trees, one of which is presented in Fig. 4 ( $T L=8$ $888, \mathrm{Cl}=0.348, \mathrm{RI}=0.789, \mathrm{RC}=0.274)$. For $\mathrm{BI}$ analysis, the general time reversible model with inverse gamma rates (GTR $+I+G$ ) was determined to be the best for ITS, LSU, tef1- $\alpha$ and tub2 loci by MrModeltest, while the most appropriate model of the act1 and rpb2 loci were Hasegawa-Kishino-Yano with inverse gamma rates model $(H K Y+I+G)$. The results of the Bayesian analyses were similar to the MP tree. The MP bootstrap support values (BS) equal to or above $50 \%$ are shown above the branches in Fig. 3 and 4. The branches with significant Bayesian posterior probabilities (BPP) equal to or above 0.95 are shown in the phylogram.

\section{Taxonomy}

Based on phylogenetic analyses and morphological examination of 88 isolates, we recognise 40 species in the present study, of which 13 are described as new species below, and we propose one new combination. The identification of many old taxa described below can currently only be preliminary and tentative, as many of them require typification before a stable species concept can be achieved.

Cytosporaceae Fr. (as 'Cytisporei'), Syst. Orb. Veg. (Lundae) 1: 118.1825

Synonym. Valsaceae Tul. \& C. Tul. (as 'Valsarum'), Select. Fung. Carpol. (Paris) 1: 180. 1861.

Type genus. Cytospora Ehrenb., Sylv. Mycol. Berol. (Berlin): 28. 1818. 
Cytospora Ehrenb., Sylv. Mycol. Berol. (Berlin): 28. 1818

Synonyms. Valsa Fr., Summa Veg. Scand., Sectio Post. (Stockholm): 410. 1849.

Leucocytospora (Pers.) Höhn., Ber. Deutsch. Bot. Ges. 35: 352. 1917. Leucostoma (Nitschke) Höhn., Ber. Deutsch. Bot. Ges. 35: 637. 1917. Valsella Fuckel, Jahrb. Nassauischen Vereins Naturk. 23-24: 203. 1870. Valseutypella Höhn., Ann. Mycol. 16: 224. 1919.

Additional synonyms in MycoBank.

Plant pathogenic, mostly causing canker diseases. Sexual morph: Ascostromata solitary, immersed in vascular plant tissues, slightly to strongly erumpent through the bark surface. Stromatic tissues prosenchymatous or pseudoparenchymatous, sometimes delimited by a black marginal line (conceptacle). Perithecial ascomata inclined to upright, in valsoid or diatrypelloid configurations, immersed, usually embedded in ectostromatic disc, with beaks converging at surface. Ostioles numerous per disc, periphysate; walls of perithecia bilayered, narrow, outer layer of textura epdermoidea to textura angularis. Paraphyses may be lacking at maturity but usually present, often collapsed and broad. Asci free, narrow, ellipsoid to clavate, apical ring refractive. Ascospores hyaline, allantoid, aseptate, thin-walled, smooth, biseriate, 4-8 or polysporous per ascus. Asexual morph: Pycnidial stromata ostiolate, immersed in vascular plant tissues, slightly to strongly erumpent through the bark surface, sometimes delimited by a black marginal line (conceptacle). Ectostromatic disc prominent or lacking, one to few ostioles per disc. Locules single, undivided to multiple chambered with invaginations, globoid to flattened toroid, in ectostroma or embedded in entostroma, sometimes with a column; wall bilayered, outer layer prosenchymatous, ultimately sclerenchymatous. Conidiophores borne along the locules, hyaline, branched or not, thin-walled, normally embedded in a gelatinous layer. Conidiogenous cells enteroblastic, phialidic, sub-cylindrical to cylindrical, tapering towards apices. Conidia hyaline, allantoid, eguttulate, smooth, aseptate, thin-walled, relatively small and narrow (adapted from Adams et al. 2005).

\section{Cytospora ailanthicola X.L. Fan \& C.M. Tian, sp. nov. - Myco- Bank MB830146; Fig. 5}

Etymology. The name reflects the host genus from which it was collected, Ailanthus.

Sexual morph not observed. Pycnidial stromata ostiolate, immersed in bark, scattered, producing black area on bark, circular to ovoid, with multiple locules, occasionally slightly erumpent through the surface. Conceptacle absent. Ectostromatic disc inconspicuous, producing one ostiole per disc when mature. Ostiole in the centre of the disc, black, conspicuous, (65-)70$100(-130) \mu \mathrm{m}$ diam. Locules numerous, subdivided frequently by invaginations with common walls, (530-)600-1300(-1400) $\mu \mathrm{m}$ diam. Conidiophores borne along the locules hyaline, branched at base, middle, or unbranched, thin-walled, occasionally septate, $(7-) 8.5-17(-18) \times 1-1.5 \mu \mathrm{m}$, embedded in a gelatinous layer. Conidiogenous cells enteroblastic, phialidic, sub-cylindrical, 4-7.5(-9) ×1-1.5 $\mu \mathrm{m}$, tapering towards apices; arranged in rosettes. Conidia hyaline, allantoid, eguttulate, smooth, aseptate, thin-walled, (4-)4.5-5 × $1.5 \mu \mathrm{m}$.

Culture characteristics - On PDA, colonies fast growing, up to $9 \mathrm{~cm}$ diam after $3 \mathrm{~d}$, with fluffy and whitish aerial mycelium, producing black pycnidia with cream to yellowish conidial drops exuding from the ostioles after $30 \mathrm{~d}$. Pycnidia sparse and distributed irregularly on the medium surface.
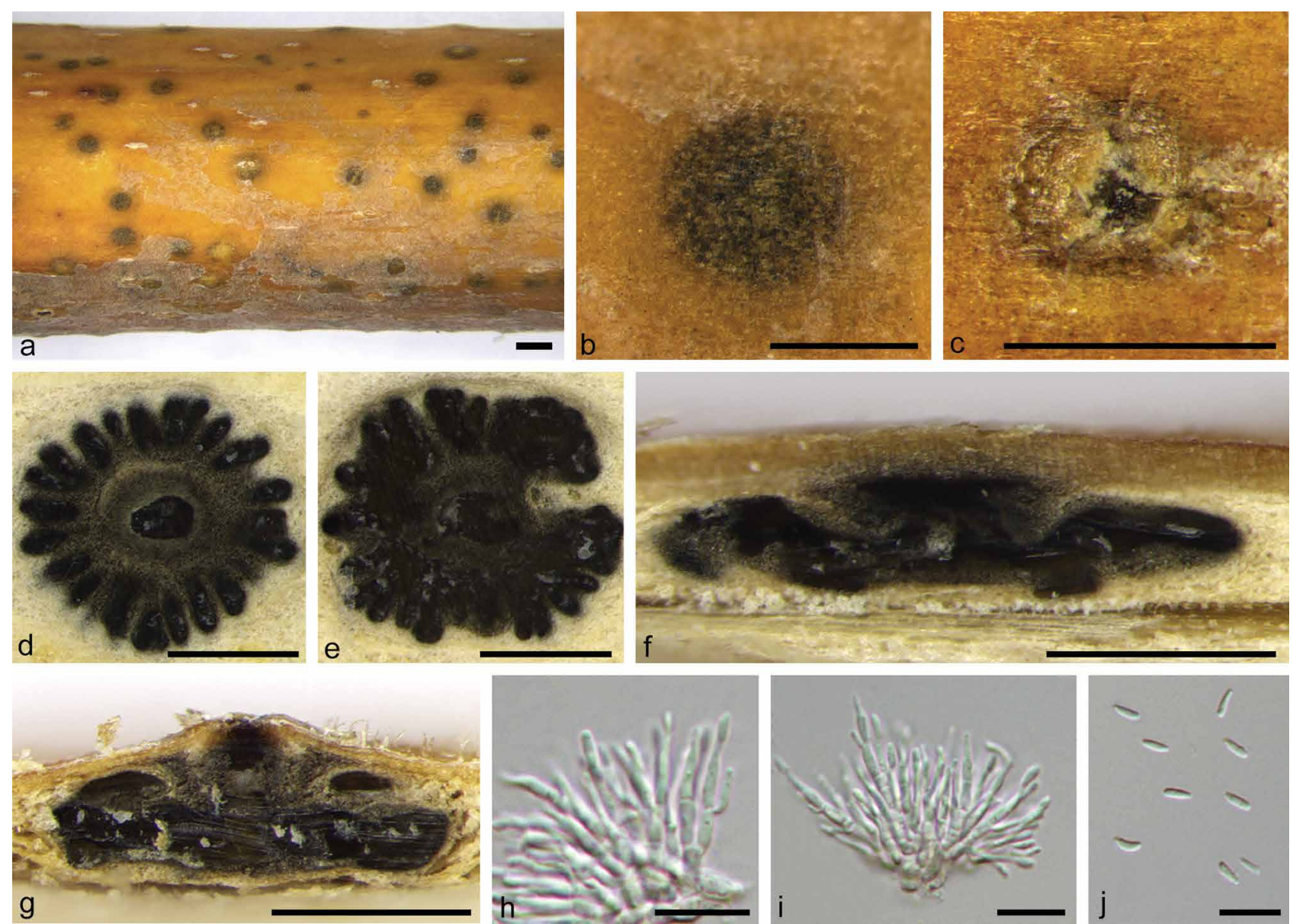

Fig. 5 Cytospora ailanthicola on Ailanthus altissima (BJFC-S550). a-c. Habit of conidiomata on branch; $d-e$. transverse section through conidiomata; $f-g$. longitudinal section through conidiomata; $h-i$. conidiogenous cells with attached conidia; $j$. conidia. $-\mathrm{Scale} b a r s: a=1 \mathrm{~mm} ; \mathrm{b}-\mathrm{g}=0.5 \mathrm{~mm} ; \mathrm{h}-\mathrm{j}=10 \mu \mathrm{m}$. 
Material examined. CHINA, Ningxia Province, Zhongwei City, Zhongning County, Qukou, N37³9'34.26" E10550'45.59", from branches of Ailanthus altissima, 3 June 2012, X.L. Fan (holotype BJFC-S550, ex-type living culture CFCC 89970).

Notes - Cytospora ailanthicola is described being associated with canker disease of Ailanthus altissima in China. This species is characterised by having pycnidia immersed in the bark, and by producing a black area on the bark, with inconspicuous ectostromatic disc and multiple locules (600-1300 $\mu \mathrm{m}$ ), which differs from $C$. chrysosperma by the grey to black, nearly flat, and circular to ovoid disc (Adams et al. 2005, Fan et al. 2014b). Cytospora ailanthi was recorded from Ailanthus altissima, but without any available morphological details, specimens or DNA data. Saccardo (1884) listed this name under the heading 'Species Imperfecte Descriptue' without supplementary information. Grove (1935) provided a description as having totally immersed small pycnidia $(250-300 \mu \mathrm{m})$, and slender conidia $(5-6 \times 1 \mu \mathrm{m})$, which can be distinguished from Cytospora ailanthicola. Spielman (1985) treated Cytospora ailanthi as a synonym of $C$. ceratosperma (syn. C. sacculus). The current multi-gene phylogram indicated a distinction from all available Cytospora strains, thus Cytospora ailanthicola is considered to represent a new species from Ailanthus (Fig. 4).

Cytospora atrocirrhata Gvrit., Mikol. Fitopatol. 7: 547. 1973 — Fig. 6

Description - See Fan et al. (2015a).

Materials examined. CHINA, Qinghai Province, Xining City, Xishan Botanical Garden, E101 $44^{\circ} 48.92^{\prime \prime}$ N36 $37^{\circ} 25.89^{\prime \prime}$, from branches of Juglans regia, 19 Aug. 2012, X.L. Fan (BJFC-S649, living culture CFCC 89615); ibid., BJFC-S650, living culture CFCC 89616.

Notes - Cytospora atrocirrhata was previously recorded as pathogen associated with cankers on Salix and Populus
(Gvritishvili 1973, Fotouhifar et al. 2010), as well as associated with Juglans regia in China (Fan et al. 2015b). This species is identified by having an undivided single locule surrounded by a black conceptacle, and secreting a lightly red pigment in the PDA medium, representing a different morphological section from the known Cytospora sections of Adams et al. (2005).

\section{Cytospora beilinensis X.L. Fan \& C.M. Tian, sp. nov. - Myco- Bank MB830147; Fig. 7}

Etymology. Named after the location from where it was collected, Beilin.

Sexual morph not observed. Pycnidial stromata ostiolate, immersed in bark, scattered, nearly flat, slightly erumpent through the bark surface, with multiple locules. Conceptacle absent. Ectostromatic disc amber to dark brick, conspicuous, triangular to circular, (200-)230-360 (-400) $\mu \mathrm{m}$ diam, with one ostiole per disc. Ostiole black, conspicuous, (55-)60-90(-105) $\mu \mathrm{m}$ diam. Locules numerous, subdivided frequently by invaginations with common walls, $(600-) 650-800(-860) \mu \mathrm{m}$ diam. Conidiophores borne along the locules, hyaline, branched at base or unbranched, thin-walled, (9-)9.5-18(-20)×1.5-2 $\mu \mathrm{m}$, embedded in a gelatinous layer. Conidiogenous cells enteroblastic, phialidic, sub-cylindrical to cylindrical, $6.5-9 \times 1.5-2 \mu \mathrm{m}$, tapering towards the apices. Conidia hyaline, allantoid, eguttulate, smooth, aseptate, thin-walled, (5-)6-6.5(-7) × 1-1.5 $\mu \mathrm{m}$.

Culture characteristics - On PDA, colonies initially white, growing up to $6.5 \mathrm{~cm}$ diam after $3 \mathrm{~d}$ and entirely covering the $9 \mathrm{~cm}$ Petri dish after $5 \mathrm{~d}$, lacking aerial mycelium, becoming dark mouse grey after $30 \mathrm{~d}$. Colony margin regular. Pycnidia irregularly distributed on the medium surface.

Materials examined. CHINA, Beijing City, Haidian District, campus of Beijing Forestry University (Beilin), N40 $00^{\prime} 64.31^{\prime \prime} \mathrm{E} 116^{\circ} 35^{\prime} 04.26 "$, from stem and branches of Pinus armandii, 26 May 2015, X.L. Fan (holotype BJFC-S1108, ex-type living culture CFCC 50493); ibid., living culture CFCC 50494.
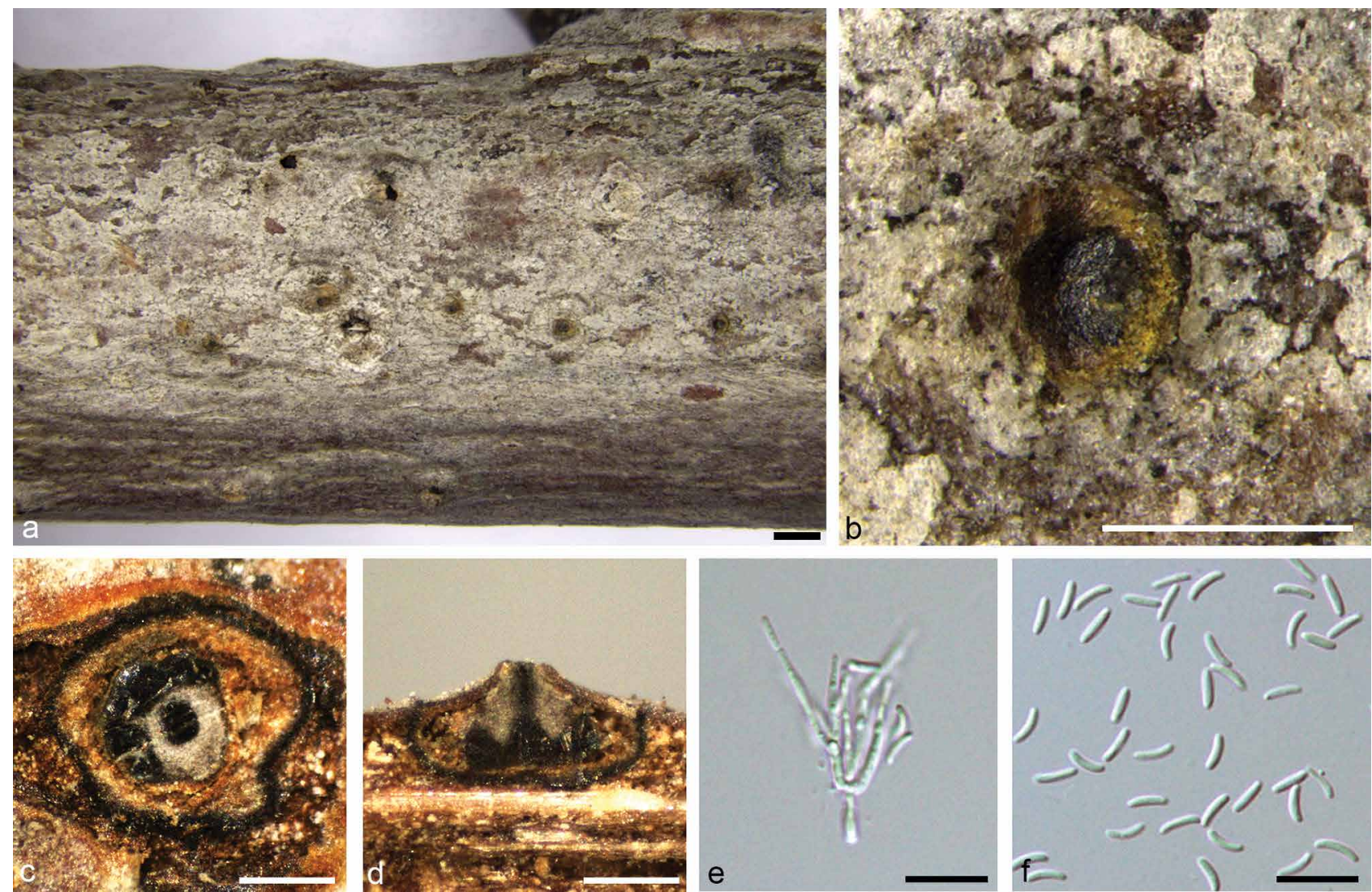

Fig. 6 Cytospora atrocirrhata on Juglans regia (BJFC-S649). a-b. Habit of conidiomata on branch; c. transverse section through conidioma; d. longitudinal section through conidioma; e. conidiogenous cells with attached conidia; f. conidia. - Scale bars: $a=1 \mathrm{~mm} ; b-d=0.5 \mathrm{~mm} ; \mathrm{e}-\mathrm{f}=10 \mu \mathrm{m}$. 


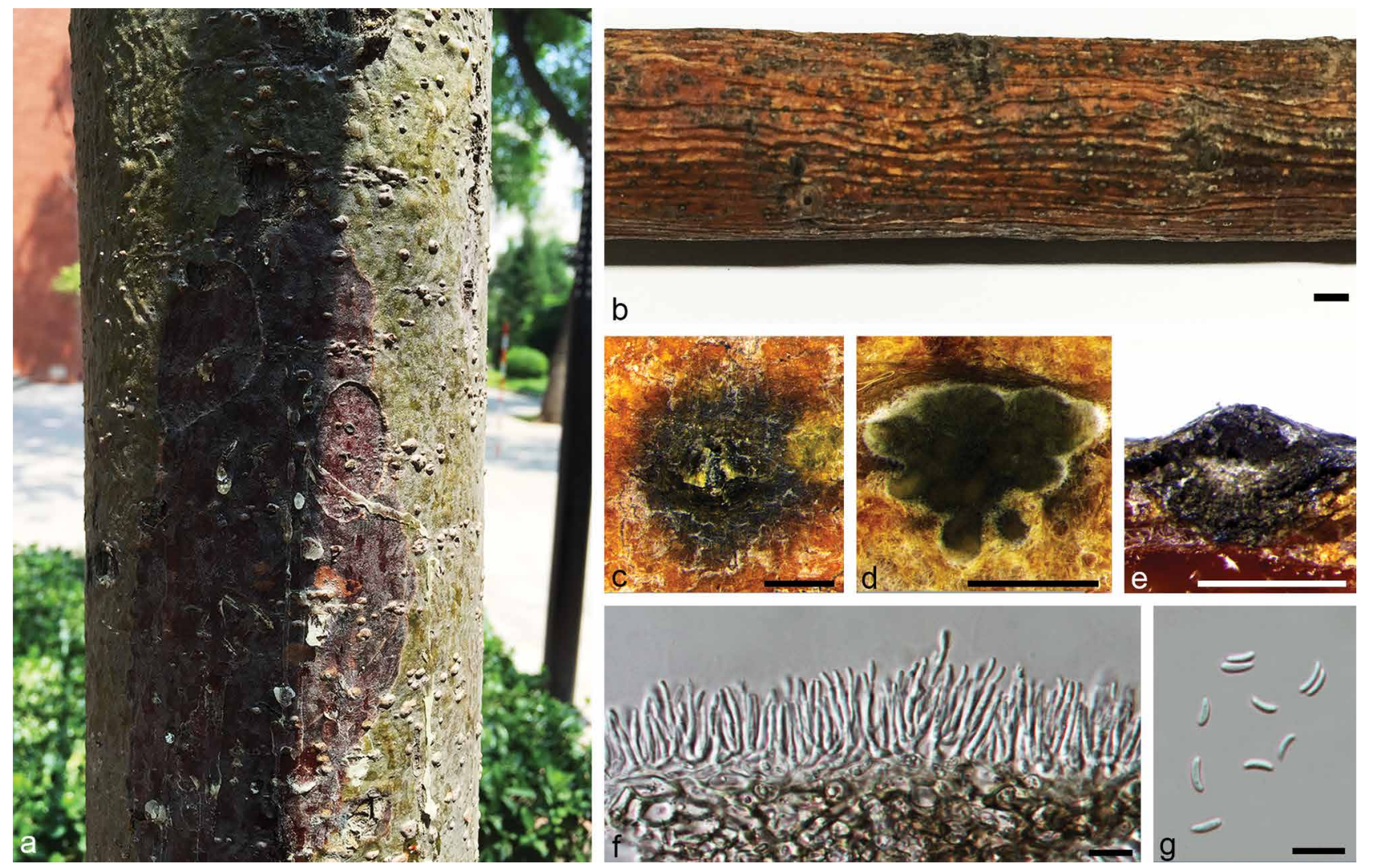

Fig. 7 Cytospora beilinensis on Pinus armandii (BJFC-S1108). a. Disease symptoms; $b-c$. habit of conidiomata on branch; $d$. transverse section through conidioma; e. longitudinal section through conidioma; $\mathrm{f}$. conidiogenous cells with attached conidia; $\mathrm{g}$. conidia. $-\mathrm{Scale}$ bars: $\mathrm{a}=5 \mathrm{~mm} ; \mathrm{c}-\mathrm{e}=0.5 \mathrm{~mm} ; \mathrm{f}-\mathrm{g}=10 \mu \mathrm{m}$.

Notes - Cytospora beilinensis is associated with canker disease of Pinus armandii at the Beijing Forestry University in Beijing. Cytospora pini was recorded from Pinus sylvestris (Saccardo 1884). Cytospora beilinensis differs from $C$. pini by the larger size of its conidia (6-6.5 ×1-1.5 vs $4 \times 1 \mu \mathrm{m}$; Saccardo 1884) and they cluster apart in the phylograms (Fig. 3, 4).

Cytospora berberidis C.M. Tian et al., Fungal Diversity 72: 43. 2015 - Fig. 8

Description - See Liu et al. (2015).

Materials examined. CHINA, Qinghai Province, Haidong City, Huzhu County, E102 ${ }^{\circ} 30^{\prime} 11.85^{\prime \prime} \mathrm{N} 36^{\circ} 56^{\prime} 12.62^{\prime \prime}$, from branches of Berberis dasystachya, 15 Aug. 2012, X.L. Fan (holotype BJFC-S681, ex-type living culture CFCC 89927); ibid., CFCC 89933.

Notes - Cytospora berberidis is a member of a group with undivided single locules. Berberis dasystachya represents a new host record for this genus (Liu et al. 2015).

Cytospora bungeanae X.L. Fan \& C.M. Tian, sp. nov. - MycoBank MB830148; Fig. 9

Etymology. The name reflects the host species from which it was collected, Pinus bungeana.

Sexual morph not observed. Pycnidial stromata ostiolate, immersed in bark, scattered, nearly flat, slightly erumpent through the bark surface in a large area, with multiple locules. Conceptacle absent. Ectostromatic disc dark grey to black, inconspicuous, circular, (110-)130-205(-220) $\mu \mathrm{m}$ diam, with one ostiole per disc. Ostiole black, inconspicuous, (40-)50-70(-85) $\mu \mathrm{m}$ diam. Locules numerous, irregular, subdivided frequently by invaginations with common walls, (1150-)1220-1480(-1600) $\mu \mathrm{m}$ diam. Conidiophores borne along the locules, hyaline, branched at the base, in the middle, or unbranched, thin-walled, $15-27(-30) \times 1.5-2 \mu \mathrm{m}$, embedded in a gelatinous layer.
Conidiogenous cells enteroblastic, phialidic, sub-cylindrical to cylindrical, $5.5-9(-10) \times 1.5 \mu \mathrm{m}$, tapering towards apices. Conidia hyaline, allantoid, eguttulate, smooth, aseptate, thinwalled, $4-5(-5.5) \times 1 \mu \mathrm{m}$.

Culture characteristics - On PDA, colonies initially white to pale white, becoming cinnamon to brick in the centre and olivaceous to olivaceous black at the margin, secreting a sienna pigment. Colonies thin with a uniform texture, lacking aerial mycelium, growing up to $7.5 \mathrm{~cm}$ after $30 \mathrm{~d}$, with an irregular edge. Pycnidia irregularly distributed on culture surface.

Materials examined. CHINA, Shanxi Province, Taiyuan City, Wanbailin Forest Park, N37 $54^{\prime} 19.12^{\prime \prime}$ E $112^{\circ} 31^{\prime} 46.75^{\prime \prime}$, on branches of Pinus bungeana, 16 Apr. 2014, X.L. Fan \& B. Cao (holotype BJFC-S1106, ex-type living culture CFCC 50495); ibid., living culture CFCC 50496.

Notes - Cytospora bungeanae is a unique Cytospora species isolated from Pinus bungeana in China. It has multiple locules without conceptacle which is commonly observed in Cytospora spp., but the molecular phylogenies show a position clearly distinct from all other strains included in this study. Therefore, we describe this species as new based on DNA sequence data and morphology.

Cytospora carbonacea Fr., Syst. Mycol. (Lundae) 2: 544. 1823 - Fig. 10

Description - See Yang et al. (2015).

Material examined. CHINA, Qinghai Province, Haidong city, Pingan County, N36 $28^{\circ} 50.48^{\prime \prime} \mathrm{E} 102^{\circ} 10^{\prime} 03.29^{\prime \prime}$, from twigs and branches of Ulmus pumila, 15 Aug. 2012, X.L. Fan (BJFC-S630, living culture CFCC 89947).

Notes - Cytospora carbonacea has been previously recorded from Ulmus americana, U. campestris and U. minor in Germany and Iran (Fotouhifar et al. 2010). The first report of this species in China was from Syzygium aromaticum (Zhang et al. 2014). Yang et al. (2015) described this species from U. pumila in China with a detailed description and wide distribution. 

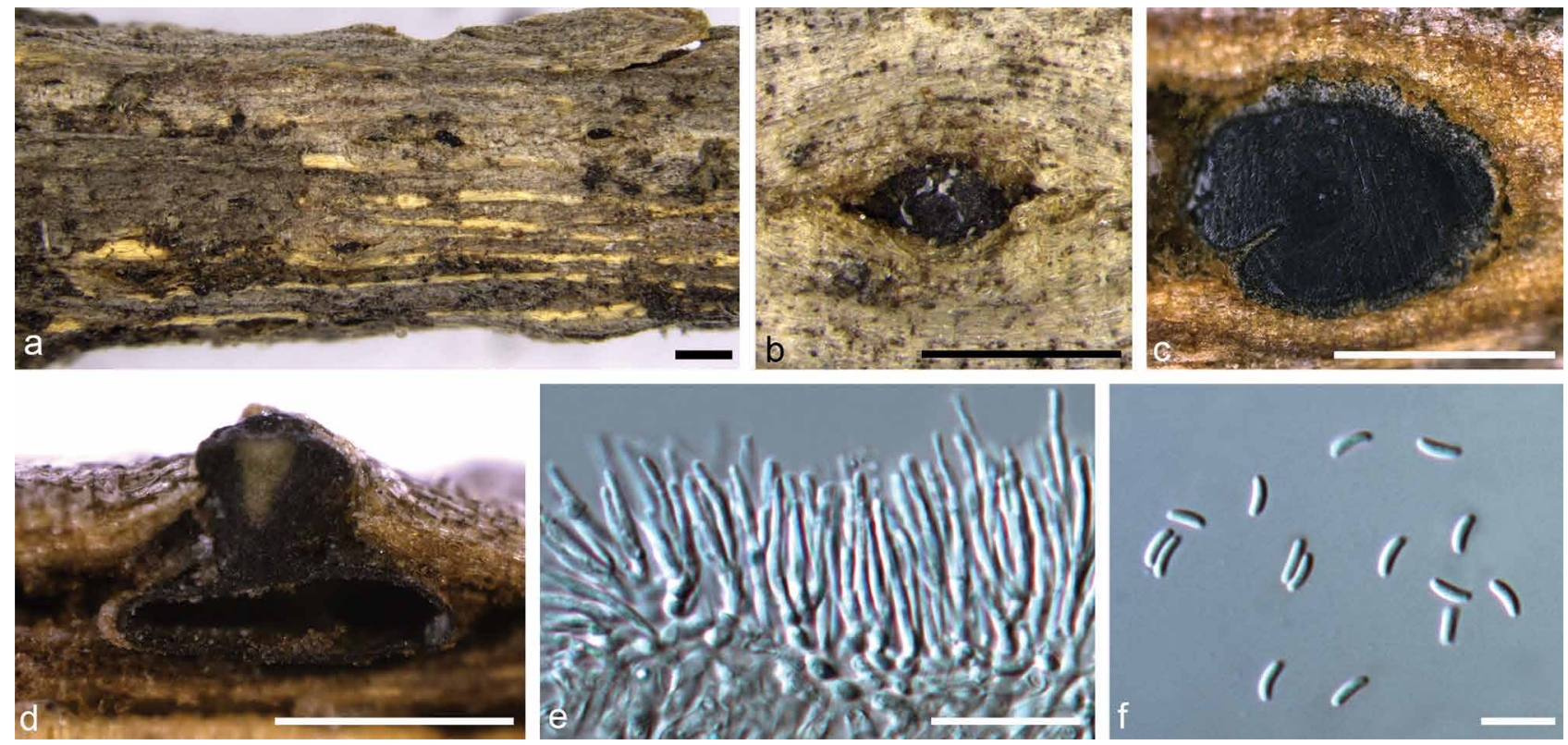

Fig. 8 Cytospora berberidis on Berberis dasystachya (BJFC-S681). a-b. Habit of conidiomata on branch; c. transverse section through conidioma; d. longitudinal section through conidioma; e. conidiogenous cells with attached conidia; f. conidia. - Scale bars: $a=1 \mathrm{~mm} ; b-d=0.5 \mathrm{~mm} ; e-f=10 \mu \mathrm{m}$.
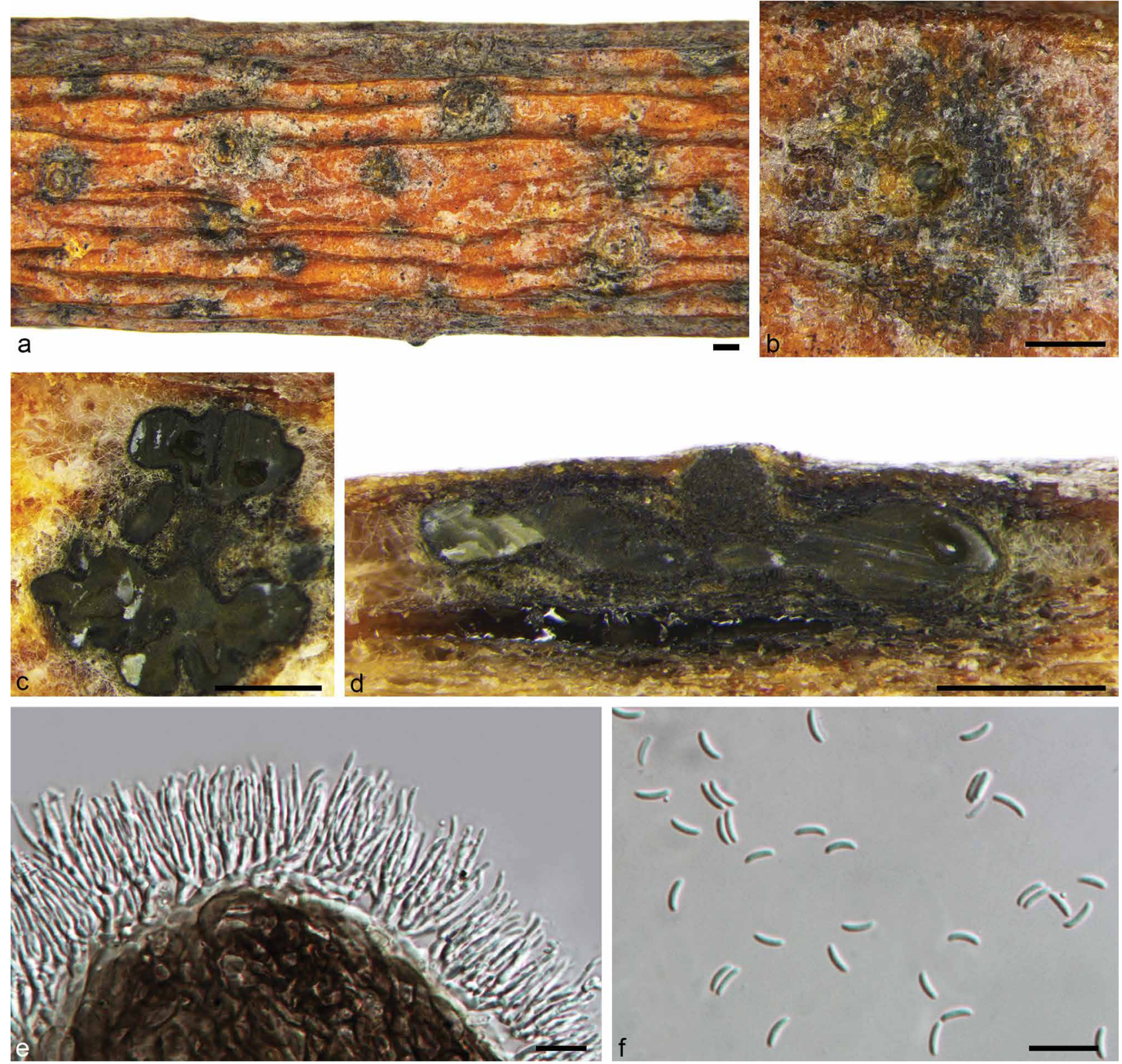

Fig. 9 Cytospora bungeanae on Pinus bungeana (BJFC-S1106). a-b. Habit of conidiomata on branch; c. transverse section through conidioma; d. longitudinal section through conidioma; e. conidiogenous cells with attached conidia; $f$. conidia. - Scale bars: $a=1 \mathrm{~mm} ; b-d=0.5 \mathrm{~mm} ; e-f=10 \mu \mathrm{m}$. 

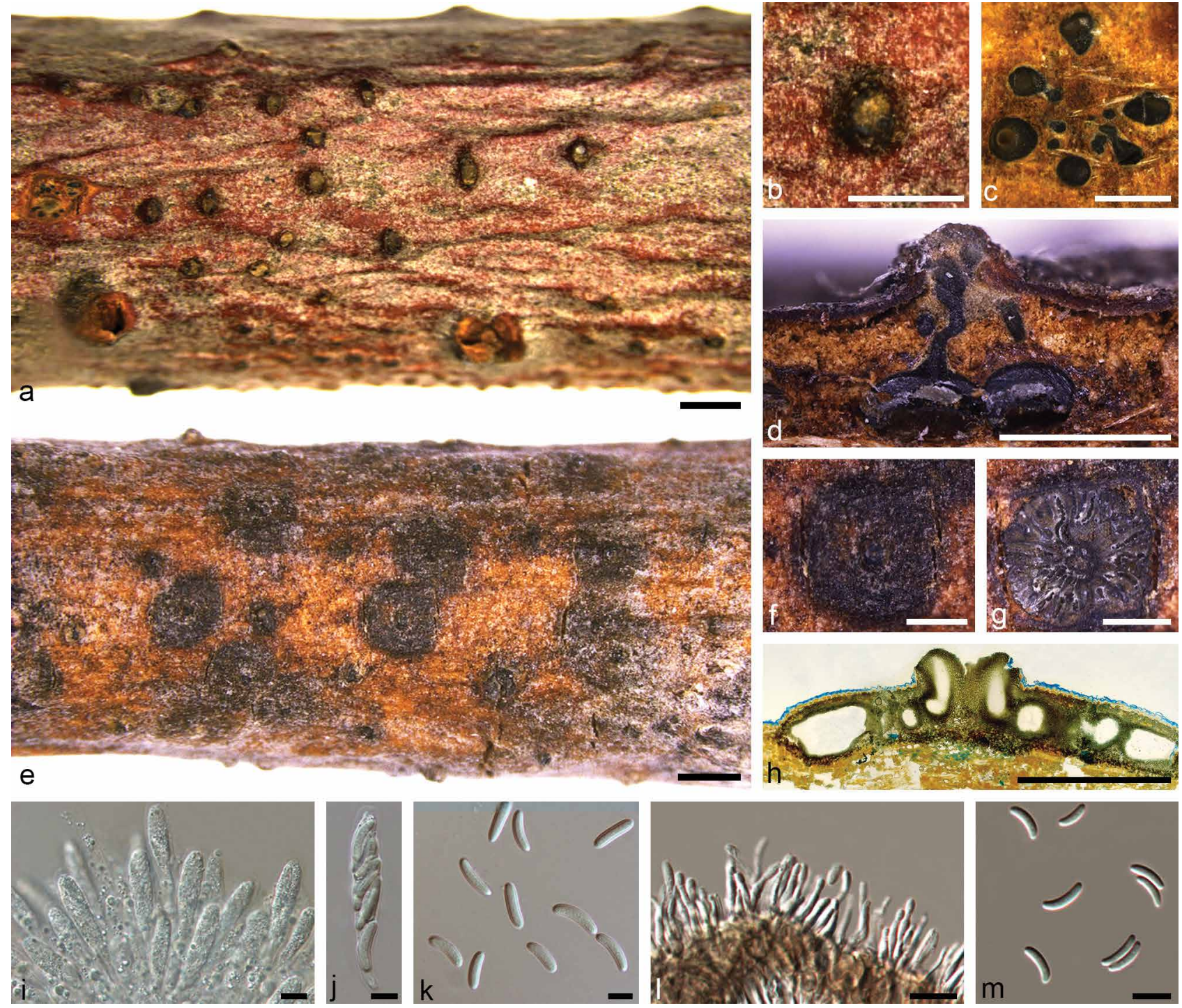

Fig. 10 Cytospora carbonacea on Ulmus pumila (BJFC-S630). a-b. Habit of ascostromata on branch; c. transverse section through ascostroma; d. longitudinal section through ascostroma; $\mathrm{e}-\mathrm{f}$. habit of conidiomata on branch; $\mathrm{g}$. transverse section through conidioma; $\mathrm{h}$. longitudinal section through conidioma; $\mathrm{i}-\mathrm{j}$. asci; k. ascospores; I. conidiogenous cells with attached conidia; $\mathrm{m}$. conidia. - Scale bars: $\mathrm{a}, \mathrm{e}=1 \mathrm{~mm} ; \mathrm{b}-\mathrm{d}, \mathrm{f}-\mathrm{h}=0.5 \mathrm{~mm}$; $\mathrm{i}-\mathrm{m}=10 \mu \mathrm{m}$.

Cytospora celtidicola X.L. Fan \& C.M. Tian, sp. nov. - MycoBank MB830149; Fig. 11 Celtis.

Etymology. The name reflects the host genus from which it was collected,

Sexual morph not observed. Pycnidial stromata ostiolate, immersed in bark, scattered, nearly flat, slightly erumpent through the bark surface in a large area, with multiple locules. Conceptacle absent. Ectostromatic disc dark grey to black, inconspicuous, circular, (140-)150-220(-230) $\mu \mathrm{m}$ diam, with one ostiole per disc. Ostiole dark grey to black, inconspicuous, (40-)45$60(-70) \mu \mathrm{m}$ diam. Locules undivided, circular to ovoid, occasionally wrinkled, (640-)700-1220(-1350) um diam. Conidiophores borne along the locules, hyaline, branched at the base, in the middle or unbranched, thin-walled, $8-18(-21) \times 1 \mu \mathrm{m}$, embedded in a gelatinous layer. Conidiogenous cells enteroblastic, phialidic, sub-cylindrical to cylindrical, 3-7 × 1.5-2 $\mu \mathrm{m}$, tapering towards the apices. Conidia hyaline, allantoid, eguttulate, smooth, aseptate, thin-walled, 5-6 $\times 1-1.5 \mu \mathrm{m}$.

Culture characteristics - On PDA, colonies initially white, growing up $6 \mathrm{~cm}$ after $3 \mathrm{~d}$, becoming pale vinaceous grey to vinaceous grey, entirely covering the $9 \mathrm{~cm}$ Petri dish after $10 \mathrm{~d}$. Colonies flat, thin with a uniform texture, lacking aerial mycelium. Pycnidia irregularly distributed on medium surface.
Materials examined. СніNA, Anhui Province, Hefei City, West Mountain Forest Park, N31 ${ }^{\circ} 85^{\prime} 85.13^{\prime \prime}$ E $117^{\circ} 28^{\prime} 12.11^{\prime \prime}$, from branches of Celtis sinensis, 18 Aug. 2014, X.L. Fan \& B. Cao (holotype BJFC-S1107, ex-type living culture CFCC 50497); ibid., BJFC-S1109, living culture CFCC 50498.

Notes - Cytospora celtidicola is associated with canker disease of Celtis sinensis in China. It represents a unique species of Cytospora diagnosed by obvious symptoms which include orange-coloured branches. Additionally, the clear multi-gene phylogram placed it in a distinct clade with high support (MP/ $\mathrm{ML} / \mathrm{BI}=100 / 100 / 1$, Fig. 4).

Cytospora ceratosperma (Tode) G.C. Adams \& Rossman, IMA Fungus 6: 147. 2015 - Fig. 12

Basionym. Sphaeria ceratosperma Tode, Fung. Mecklenb. Sel. (Lüneburg) 2: 53.1791 .

Synonyms. Sphaeria sacculus Schwein., Schr. Naturf. Ges. Leipzig 1: 26. 1822.

Valsa ceratosperma (Tode) Maire, Publ. Inst. Bot. 3(4): 20. 1937.

Cytospora sacculus (Schwein.) Gvrit., Mikol. Fitopatol. 3: 207. 1969.

Sexual morph not observed. Pycnidial stromata ostiolate, immersed in bark, scattered, erumpent through the bark surface, discoid to conical, with multiple locules. Conceptacle absent. Ectostromatic disc light brown to grey, circular to ovoid, (160-) $170-240(-255) \mu \mathrm{m}$ diam, with one ostiole per disc. Ostiole 

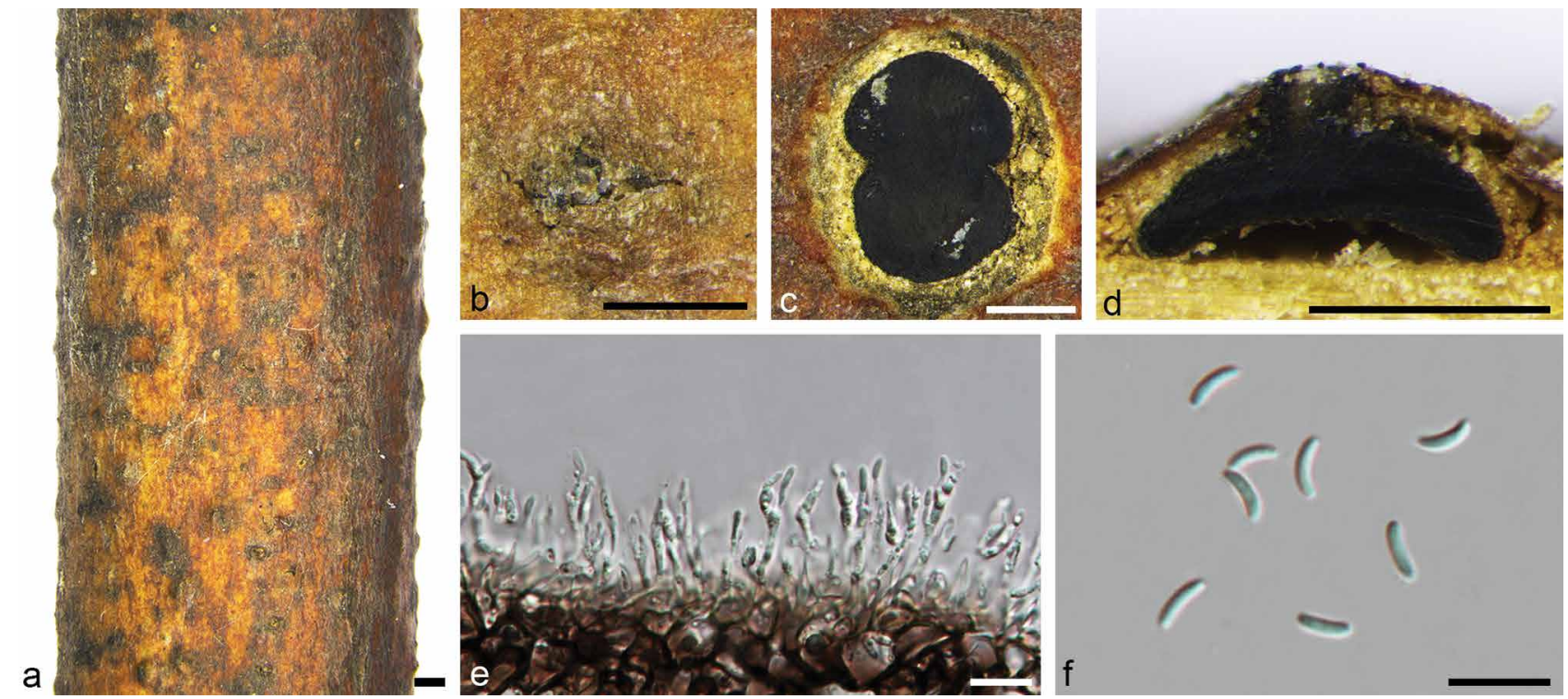

Fig. 11 Cytospora celtidicola on Celtis sinensis (BJFC-S1107). a-b. Habit of conidiomata on branch; c. transverse section through conidioma; d. longitudinal section through conidioma; e. conidiogenous cells with attached conidia; f. conidia. - Scale bars: $a=1 \mathrm{~mm} ; b-d=0.5 \mathrm{~mm} ; e-f=10 \mu \mathrm{m}$.
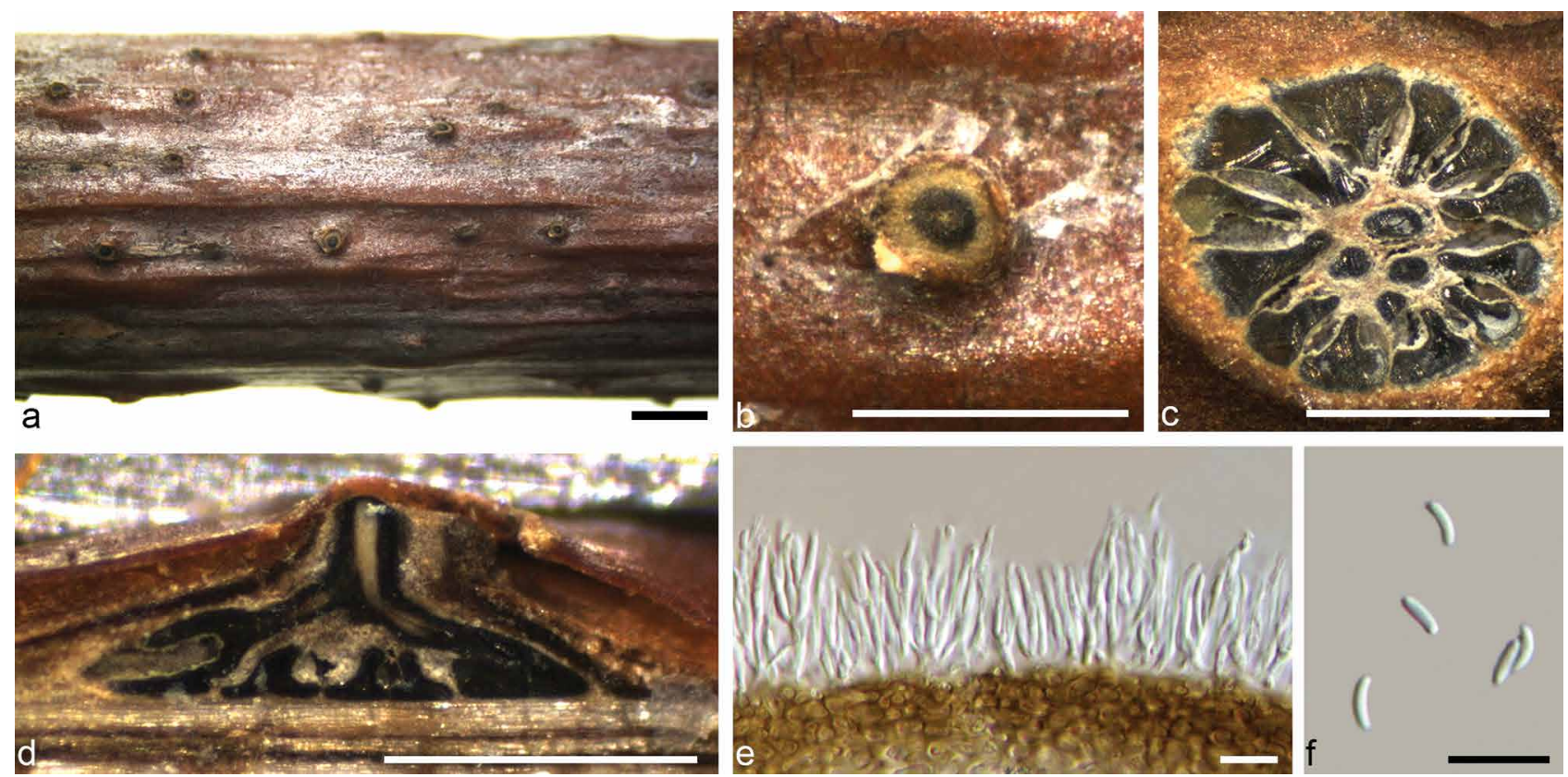

Fig. 12 Cytospora ceratosperma on Juglans regia (BJFC-S774). a-b. Habit of conidiomata on branch; c. transverse section through conidioma; d. longitudinal section through conidioma; e. conidiogenous cells with attached conidia; $f$. conidia. - Scale bars: $a=1 \mathrm{~mm} ; b-d=0.5 \mathrm{~mm} ; e-f=10 \mu \mathrm{m}$.

in the centre of the disc, dark grey to black, conspicuous, (70-)80-100(-115) $\mu \mathrm{m}$ diam. Locules numerous, arranged circularly or elliptically with independent walls, (480-)510$960(-1050) \mu \mathrm{m}$ diam. Conidiophores borne along the locules, hyaline, branched at base, middle, or unbranched, thin-walled, $12-23(-25.5) \times 1.5-2 \mu \mathrm{m}$, embedded in a gelatinous layer. Conidiogenous cells enteroblastic, phialidic, sub-cylindrical to cylindrical, $7.5-12(-14) \times 1.5-2 \mu \mathrm{m}$, tapering towards apices. Conidia hyaline, allantoid, eguttulate, smooth, aseptate, thinwalled, 3.5-5(-5.5) × 1(-1.5) $\mu \mathrm{m}$.

Culture characteristics - On PDA, colonies white with slight pale colour at the centre after $3 \mathrm{~d}$, growing up to $3.5 \mathrm{~cm}$ diam, becoming greyish sepia after $7 \mathrm{~d}$ and finally olivaceous grey after $30 \mathrm{~d}$, reaching $9 \mathrm{~cm}$ diam. Colonies flat, thin with a uniform texture, lacking aerial mycelium. Pycnidia are sparse and distributed irregularly on culture medium surface.
Materials examined. CHINA, Gansu Province, Gannan City, Diebu County,

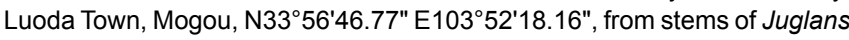
regia, 11 Aug. 2012, X.L. Fan (BJFC-S774, living culture CFCC 89624); ibid., BJFC-S775, living culture CFCC 89625.

Notes - Cytospora ceratosperma has been recorded from a range of host plants, e.g., Juglans, Malus, Pyrus, Rosa and Ziziphus in China and Iran (Teng 1963, Tai 1979, Wang et al. 2007, Fotouhifar et al. 2010, Du et al. 2013, Fan et al. 2015a). Cytospora ceratosperma has many taxonomic synonyms and confusion exists regarding its morphology and DNA phylogeny. Adams et al. (2005) narrowed the morphological species concept of Valsa ceratosperma (syn. C. sacculus) and considered it as a distinct species with multi-ostioles per disc, independent locule walls and greyish to yellow-brown and brownish grey colonies, and provided the first ITS sequence data. Rossman et al. (2015) recommended to use C. ceratosperma, having priority over $\mathrm{V}$. ceratosperma. 

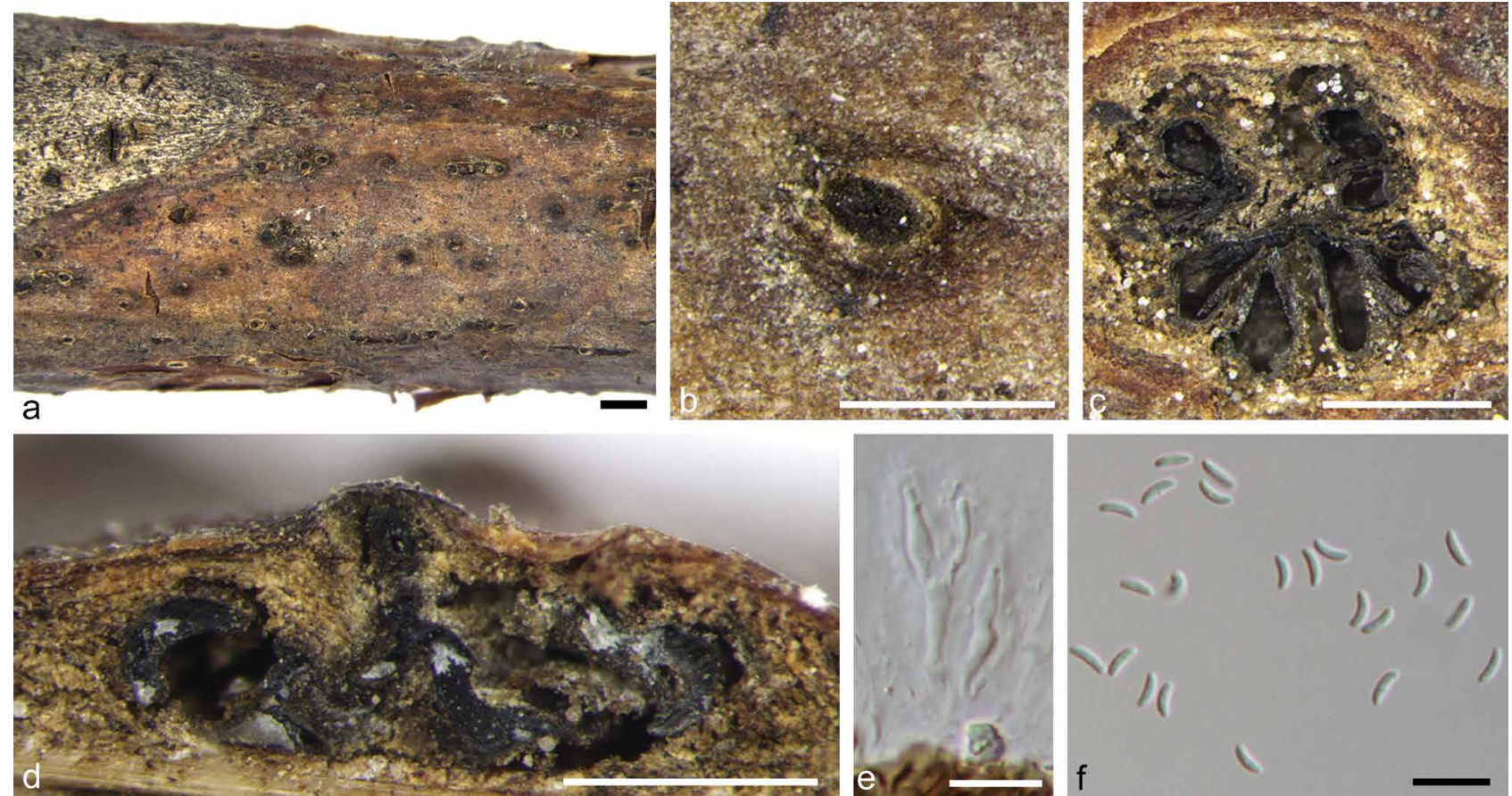

Fig. 13 Cytospora ceratospermopsis on Juglans regia (BJFC-S567). a-b. Habit of conidiomata on branch; c. transverse section through conidioma; d. Iongitudinal section through conidioma; e. conidiogenous cells with attached conidia; f. conidia. - Scale bars: $a=1 \mathrm{~mm} ; b-d=0.5 \mathrm{~mm} ; e-f=10 \mu \mathrm{m}$.

\section{Cytospora ceratospermopsis C.M. Tian \& X.L. Fan, sp. nov. — MycoBank MB830150; Fig. 13 \\ Etymology. Named after its morphological similarity to C. ceratosperma.}

Sexual morph not observed. Pycnidial stromata ostiolate, immersed in bark, scattered, erumpent through the bark surface, discoid to conical, with multiple locules. Conceptacle absent. Ectostromatic disc pale brown to grey, circular to ovoid, (170-) $200-300(-340) \mu \mathrm{m}$ diam, with one ostiole per disc. Ostiole in the centre of the disc, dark grey to black, conspicuous, (55-)60$90(-100) \mu \mathrm{m}$ diam. Locules numerous, arranged circularly or elliptically with independent walls, (800-)850-1300(-1400) $\mu \mathrm{m}$ diam. Conidiophores borne along the locules, hyaline, branched at the middle or unbranched, thin-walled, 13-21(-22) $\times 2-2.5$ $\mu \mathrm{m}$, embedded in a gelatinous layer. Conidiogenous cells enteroblastic, phialidic, sub-cylindrical to cylindrical, $5-8 \times 2-3 \mu \mathrm{m}$, tapering towards the apices. Conidia hyaline, allantoid, eguttulate, smooth, aseptate, thin-walled, (4.5-)5-5.5(-6) × 1-1.5 $\mu \mathrm{m}$.

Culture characteristics - On PDA, colonies white with buff in the centre after $3 \mathrm{~d}$, growing up to $6.5 \mathrm{~cm}$ diam, becoming greyish with isabelline in the centre, reaching $8.5 \mathrm{~cm}$ diam after $30 \mathrm{~d}$; sterile.

Materials examined. CHINA, Shaanxi Province, Xianyang City, Yangling County, N34 ${ }^{\circ} 14^{\prime} 06.08^{\prime \prime} \mathrm{E} 108^{\circ} 00^{\prime} 48.30^{\prime \prime}$, on stems of Juglans regia, 30 May 2012, X.L. Fan (holotype BJFC-S567, ex-type living culture CFCC 89626); ibid., BJFC-S568, living culture CFCC 89627.

Notes - Cytospora ceratospermopsis is associated with canker disease of Juglans regia in China. Fan et al. (2015a) temporarily identified CFCC 89626 and CFCC 89627 as Cytospora ceratosperma (syn. C. sacculus) due to their similar morphology and phylogeny. Morphologically, it differs from Cytospora ceratosperma by larger multiple locules (850-1300 vs $510-960 \mu \mathrm{m})$ with independent walls and conidial size (4.5-6 $\times 1-1.5$ vs $3.5-5 \times 1 \mu \mathrm{m}$ in C. ceratosperma). The phylogenetic inferences resolved $C$. ceratospermopsis as a distinct lineage from C. ceratosperma.
Cytospora chrysosperma (Pers.) Fr., Sylv. Mycol. Berol. (Berlin): 28. 1818 - Fig. 14

Basionym. Sphaeria chrysosperma Pers., Neues Mag. Bot. 1: 82. 1794 Synonyms. Naemaspora chrysosperma (Pers.) Pers., Observ. Mycol. (Lipsiae) 1: 80. 1796.

Valsa sordida Nitschke, Pyrenomyc. Germ. 2: 203. 1870.

Description - See Fan et al. (2014b).

Materials examined. CHINA, Gansu Province, Gannan City, Lintan County, Ligang Village, N34 ${ }^{\circ} 39^{\prime} 07.89^{\prime \prime} \mathrm{E} 103^{\circ} 27^{\prime} 14.78^{\prime \prime}$, on twigs and branches of Populus alba subsp. pyramidalis, 8 Aug. 2012, X.L. Fan (BJFC-S750, living culture CFCC 89981); Tibet Province, Shigatse City, N29²7'34.53" E89 $90^{\prime 23.08 ", ~ o n ~ t w i g s ~ a n d ~ b r a n c h e s ~ o f ~ U l m u s ~ p u m i l a, ~} 2$ Feb. 2012, X.L. Fan (BJFC-S788, living culture CFCC 89982); Shaanxi Province, Yulin City, Airport East Road, N38¹9'21.16" E109³9'54.73", from branches of Salix psammophila, 1 Aug. 2013, X.L. Fan (BJFC-S975, living culture CFCC 89629).

Notes - Cytospora chrysosperma is the type species of the genus Cytospora, and is also the most common species causing canker disease with a wide host range (Teng 1963, Tai 1979, Zhuang 2005, Adams et al. 2006, Fan et al. 2014b). According to earlier records, several plant genera are hosts to this species in China, e.g., Castanea, Morus, Populus, Salix and Ulmus (Teng 1963, Tai 1979, Zhuang 2005). Based on ITS and the multi-gene dataset the current investigation revisited the related fungi and delineated the $C$. chrysosperma complex, including C. ailanthicola, C. chrysosperma, C. joaquinensis, C. longiostiolata, C. melnikii, C. populicola, C. salicacearum, C. salicina, C. sophoriopsis and C. rostrata (Fig. 3, 4). These results suggest that this species is a common, severe pathogen in China, causing canker disease of Salicaceae hosts.

\section{Cytospora elaeagni Allesch., Hedwigia Beibl. 36: 162. 1897 —} Fig. 15

Description - See Fan et al. (2015b).

Materials examined. CHINA, Ningxia Province, Guyuan City, Changchengliang, N36 $03^{\prime} 01.77^{\prime \prime} \mathrm{E} 106^{\circ} 16^{\prime} 18.63^{\prime \prime}$, from twigs and branches of Elaeagnus angustifolia, 24 July 2013, X.L. Fan (BJFC-S965, living culture CFCC 89632); ibid., living culture CFCC 89633. 

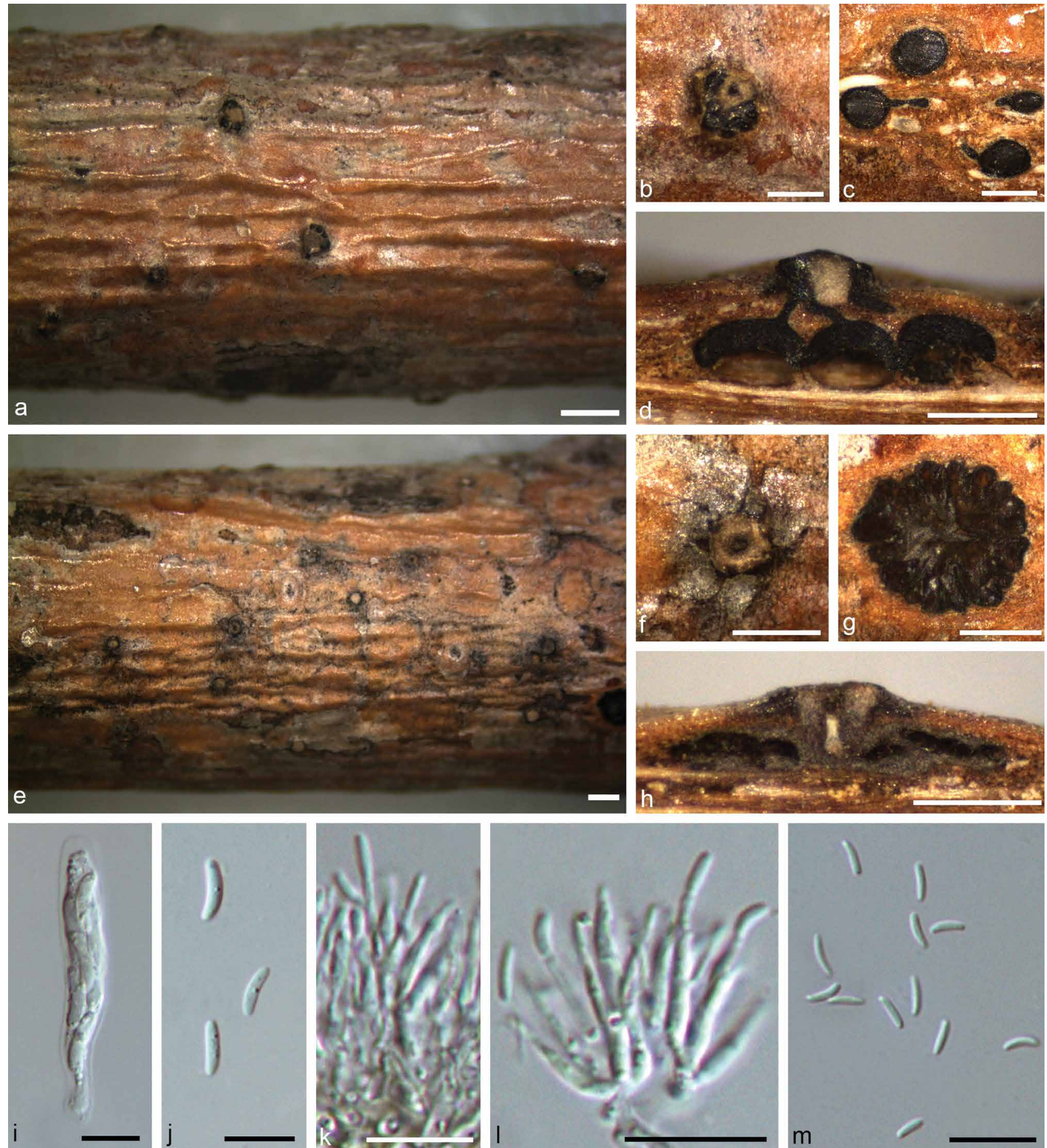

Fig. 14 Cytospora chrysosperma on Populus alba subsp. pyramidalis (BJFC-S750). a-b. Habit of ascostromata on branch; c. transverse section through ascostroma; d. longitudinal section through ascostroma; e-f. habit of conidiomata on branch; g. transverse section through conidioma; $h$. longitudinal section through conidioma; i. ascus; j. ascospores; $\mathrm{k}-\mathrm{I}$. conidiogenous cells with attached conidia; $\mathrm{m}$. conidia. $-\mathrm{Scale}$ bars: $\mathrm{a}, \mathrm{e}=1 \mathrm{~mm} ; \mathrm{b}-\mathrm{d}, \mathrm{f}-\mathrm{h}=0.5 \mathrm{~mm} ; \mathrm{i}-\mathrm{m}=10 \mu \mathrm{m}$.

Notes - Cytospora elaeagni has been recorded from Elaeagnus angustifolia in China, Germany and North America, but these records lacked any detailed descriptions, illustrations and molecular data (Sydow 1897, Zhuang 2005). Morphologically, C. elaeagni is similar to $C$. carbonacea from Ulmus spp., but can be distinguished by the smaller size and fewer number of locules, cultures secreting a pale brown pigment, and by the plant hosts (Fan et al. 2015b, Yang et al. 2015).
Cytospora erumpens Norph. et al., Mycosphere 8: 64. 2017 - Fig. 16

Description — See Norphanphoun et al. (2017).

Material examined. CHINA, Shanxi Province, Jincheng City, N35 $25^{\circ} 43.27^{\prime \prime}$ E111 ${ }^{\circ} 59^{\prime} 06.66 "$, from branches of Prunus padus, 21 Apr. 2014 X.L. Fan \& B. Cao (BJFC-S1064, living culture CFCC 50022).

Notes - Cytospora erumpens was described from dead and dying branches of Salix in Russia (Norphanphoun et al. 2017). This species can be identified as having typical leucostomalike conidiomata. The current study extended its distribution to China, and its host range to include Rosaceae. 

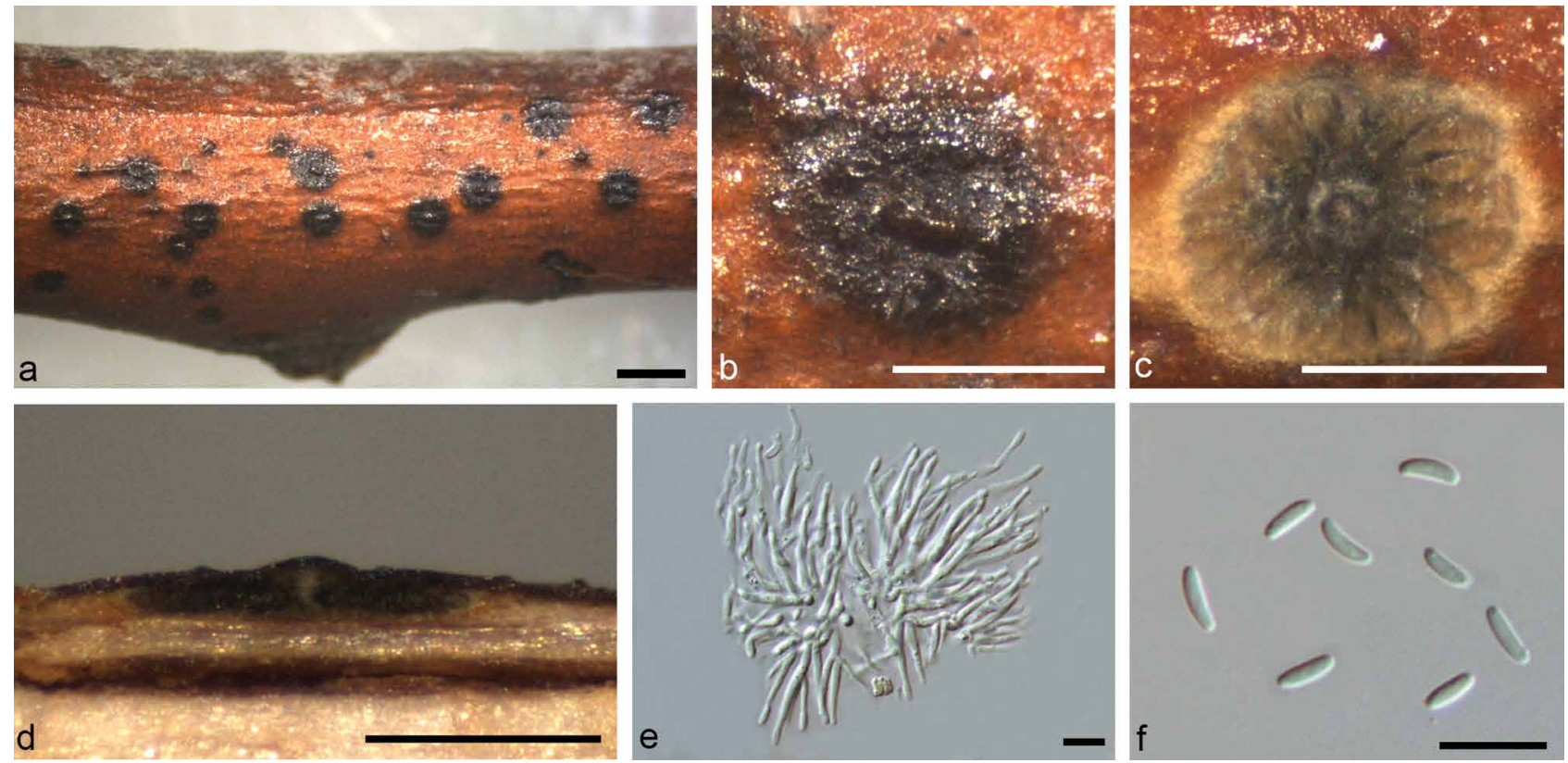

Fig. 15 Cytospora elaeagni on Elaeagnus angustifolia (BJFC-S965). a-b. Habit of conidiomata on branch; c. transverse section through conidioma; d. Iongitudinal section through conidioma; e. conidiogenous cells with attached conidia; f. conidia. - Scale bars: $a=1 \mathrm{~mm} ; b-d=0.5 \mathrm{~mm} ; e-f=10 \mu \mathrm{m}$.

Cytospora euonymicola X.L. Fan \& C.M. Tian, sp. nov. MycoBank MB830151; Fig. 17

Etymology. The name reflects the host genus from which it was described, Euonymus.

Sexual morph not observed. Pycnidial stromata ostiolate, immersed in bark, scattered, erumpent through the surface, with multiple locules. Conceptacle absent. Ectostromatic disc isabelline to dark brick, conspicuous, circular to ovoid, (220-) $240-350(-400) \mu \mathrm{m}$ diam, with one ostiole per disc. Ostiole in the centre of the disc, black, conspicuous, (50-)60-120(-125) $\mu \mathrm{m}$ diam. Locules numerous, subdivided frequently by invaginations with common walls, (950-)1150-1400(-1550) $\mu \mathrm{m}$ diam. Conidiophores hyaline, branched at the base or unbranched, thin-walled, $13-21.5(-23) \times 1.5-2 \mu \mathrm{m}$, embedded in a gelatinous layer. Conidiogenous cells enteroblastic, phialidic, subcylindrical to cylindrical, 8-11(-13.5) $\times 1-2 \mu \mathrm{m}$, tapering towards the apices. Conidia hyaline, allantoid, eguttulate, smooth, aseptate, thin-walled, (4-) 4.5-5 $1 \mu \mathrm{m}$.

Culture characteristics - On PDA, colonies initially white to greyish, growing up to $4 \mathrm{~cm}$ after $3 \mathrm{~d}$, secreting a pale brown pigment, reaching up to $9 \mathrm{~cm}$ after $7-10 \mathrm{~d}$, and becoming greyish sepia, secreting a fuscous black pigment after $30 \mathrm{~d}$. Colonies felt-like with a uniform texture. Pycnidia irregularly distributed over the medium surface.

Materials examined. CHINA, Shaanxi Province, Yulin City, Economic Development Zone, N38 ${ }^{\circ} 13^{\prime} 37.46^{\prime \prime}$ E109 ${ }^{\circ} 44^{\prime} 60.93^{\prime \prime}$, from branches of Euonymus kiautschovicus, 31 July 2013, X.L. Fan (holotype BJFC-S1105, ex-type living culture CFCC 50499); ibid., living culture CFCC 50500.

Notes - Cytospora euonymicola is associated with canker disease of Euonymus kiautschovicus. Morphologically, C. euonymicola has large, multiple locules $(1150-1400 \mu \mathrm{m})$ with large conidia $(4.5-5 \times 1 \mu \mathrm{m})$, compared to the smaller conidia of C. euonymella $(2.5 \times 0.5 \mu \mathrm{m})$ and the larger conidia of Cytospora euonymi $(8 \times 2 \mu \mathrm{m})$ and $C$. euonymina $(6.5-7.5 \times 1.5-2$ $\mu \mathrm{m})$ (Cooke 1885, Saccardo 1892). The multigene phylogenetic analysis supported this species as new with high support values $(\mathrm{ML} / \mathrm{MP} / \mathrm{BI}=100 / 100 / 1$, Fig. 4$)$.
Cytospora euonymina X.L. Fan \& C.M. Tian, sp. nov. - MycoBank MB830152; Fig. 18

Etymology. The name reflects the host genus from which it was collected, Euonymus.

Sexual morph not observed. Pycnidial stromata ostiolate, immersed in bark, scattered, producing black area on bark, erumpent through the surface, with multiple locules. Conceptacle absent. Ectostromatic disc honey to dark mouse grey, conspicuous, circular to ovoid, (190-)200-230(-250) $\mu \mathrm{m}$ diam, with one ostiole per disc. Ostiole in the centre of the disc, black, conspicuous, (60-)70-115(-120) $\mu \mathrm{m}$ diam. Locules numerous, subdivided frequently by invaginations with common walls, (650-)700-900(-1150) $\mu \mathrm{m}$ diam. Conidiophores borne along the locules, hyaline, unbranched or occasionally branched at the base or in the middle, thin-walled, 12-16.5 × 1.5-2 $\mu \mathrm{m}$, embedded in a gelatinous layer. Conidiogenous cells enteroblastic, phialidic, sub-cylindrical to cylindrical, 8.5-12 × 1.5-2 $\mu \mathrm{m}$, tapering towards the apices. Conidia hyaline, allantoid, eguttulate, smooth, aseptate, thin-walled, 6.5-7.5 × 1.5-2 $\mu \mathrm{m}$.

Culture characteristics - On PDA, colonies initially white, irregular, lacking aerial mycelium, fast growing, reaching up to $9 \mathrm{~cm}$ diam after $3 \mathrm{~d}$. Colonies pale white to light salmon after $30 \mathrm{~d}$, lacking aerial mycelium. Pycnidia distributed sparsely over the medium surface, exuding a salmon conidia mass from the ostioles.

Materials examined (all on twigs and branches of Euonymus kiautschovicus). CHINA, Shanxi Province, Datong City, Wenying Ecological Garden, N4004'32.40" E113²1'57.85", 15 Apr. 2014, X.L. Fan (holotype BJFCS1025, ex-type living culture CFCC 89993); Datong City, Wenying Ecological Garden, N4004'19.70" E113'22'20.29", 15 Apr. 2014, X.L. Fan (BJFCS1026, living culture CFCC 89999).

Notes - Cytospora euonymina is associated with canker disease of Euonymus kiautschovicus. Morphologically, C. euonymina has larger conidia $(6.5-7.5 \times 1.5-2 \mu \mathrm{m})$ as compared with conidia of $C$. euonymella $(2.5 \times 0.5 \mu \mathrm{m}$; Saccardo 1892$)$. Cytospora euonymi was similarly characterised by having pycnidia covered by the darkened cuticle compared to $C$. euonymina, whereas the author described it with 'rather small' pycnidia and larger conidia $(8 \times 2 \mu \mathrm{m})$ (Cooke 1885 , Saccardo 1892). In the current study we treat this species as new, which is also reflected by its phylogeny $(\mathrm{ML} / \mathrm{MP} / \mathrm{BI}=100 / 100 / 1)$. 

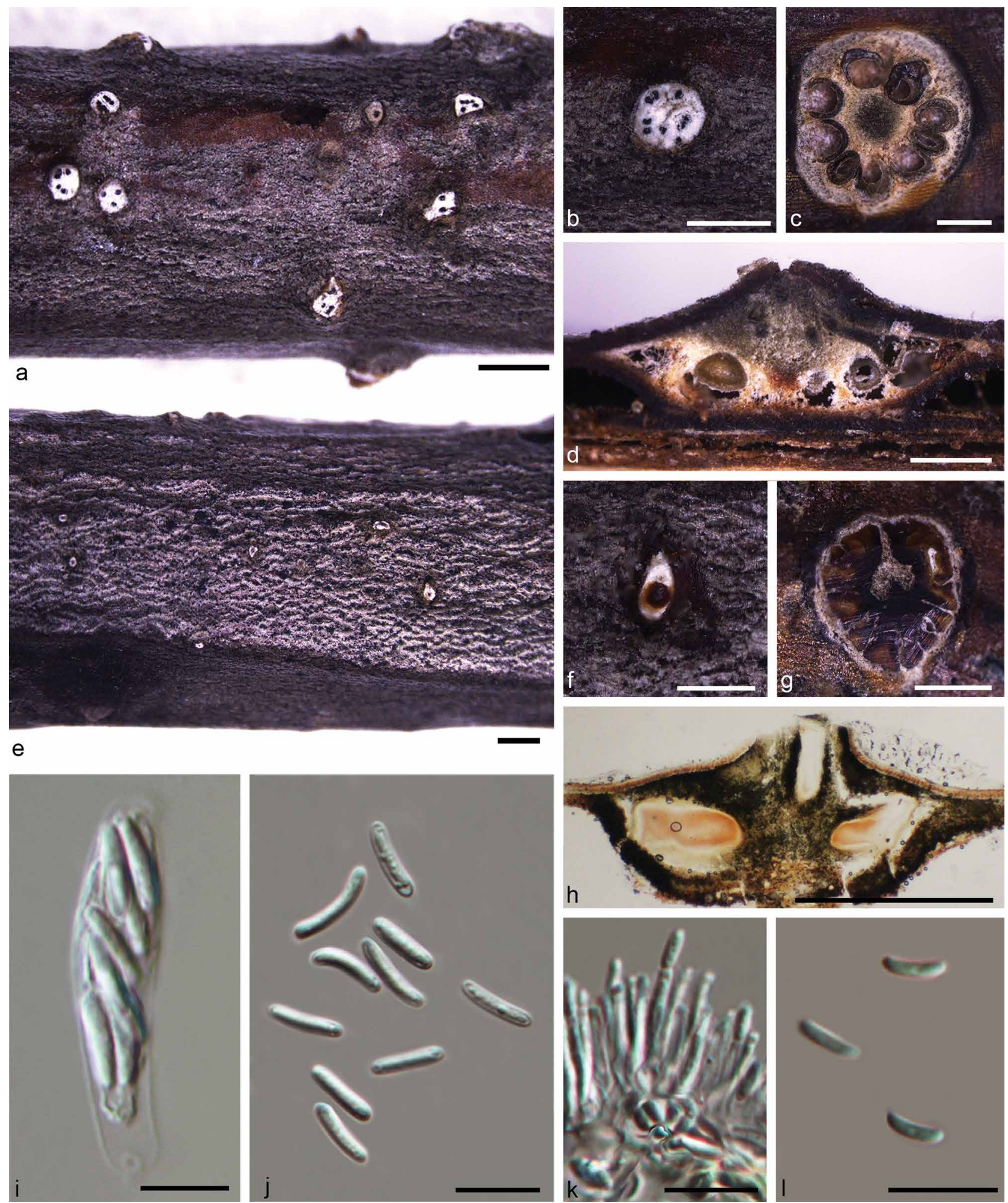

Fig. 16 Cytospora erumpens on Prunus padus (BJFC-S1064). a-b. Habit of ascostromata on branch; c. transverse section through ascostroma; d. Iongitudinal section through ascostroma; $\mathrm{e}-\mathrm{f}$. habit of conidiomata on branch; $\mathrm{g}$. transverse section through conidioma; $\mathrm{h}$. longitudinal section through conidioma; i. ascus; j. ascospores; k. conidiogenous cells with attached conidia; I. conidia. - Scale bars: $\mathrm{a}, \mathrm{e}=1 \mathrm{~mm}$; $\mathrm{b}-\mathrm{d}, \mathrm{f}-\mathrm{h}=0.5 \mathrm{~mm}$; $\mathrm{i}-\mathrm{I}=10 \mu \mathrm{m}$.

Cytospora fortunea G.C. Zhao et al., J. Northeast For. Univ. 2: 105.1991 - Fig. 19 1991.

Synonym. Valsa fortunea G.C. Zhao et al., J. Northeast For. Univ. 2: 105.

Ascostromata immersed in the bark, erumpent through the bark surface, scattered, (700-)750-1200(-1300) $\mu \mathrm{m}$ diam, with 5-18 perithecia arranged circularly or irregularly. Conceptacle absent. Ectostromatic disc inconspicuous, usually surrounded by tightly aggregated ostiolar necks, (120-)150-320(-350) $\mu \mathrm{m}$ diam, with 5-18 ostioles per disc. Ostioles numerous, violaceous black to black, concentrated, arranged irregularly in a disc, (40-)45.5-55(-75) $\mu \mathrm{m}$ diam. Perithecia dark grey to black, flask-shaped to spherical, arranged circularly or irregularly, (145-)180-350(-400) $\mu \mathrm{m}$ diam. Asci free, clavate to elongate obovoid, (26-)28.5-35(-40) × (3.5-)4-5.5(-6) $\mu \mathrm{m}$, 8-spored. Ascospores biseriate, elongate-allantoid, thin-walled, hyaline, aseptate, $(7.5-) 8-9(-9.5) \times 1.5-2 \mu \mathrm{m}$. Pycnidial stromata ostiolate, immersed in bark, scattered, erumpent through the surface, with multiple locules. Conceptacle absent. Ectostro- 

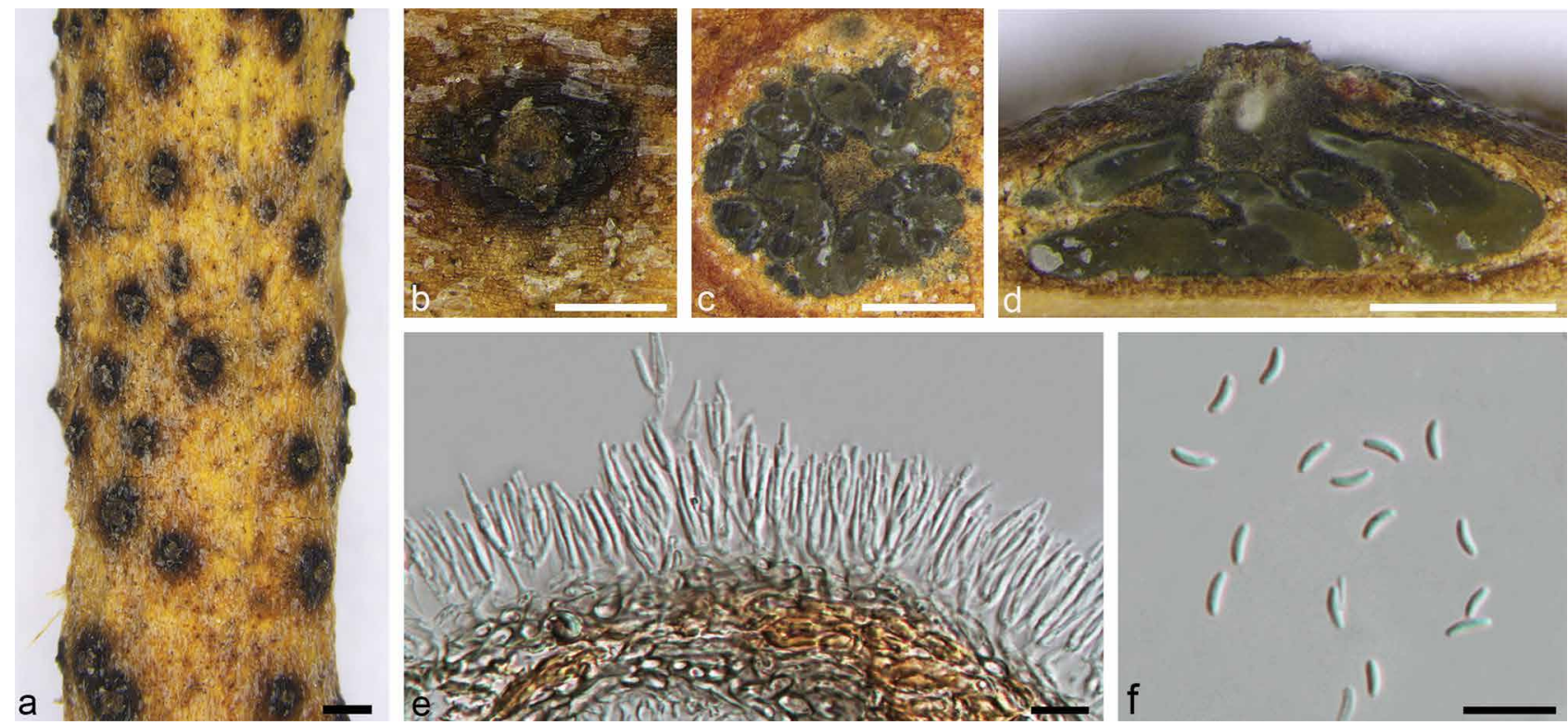

Fig. 17 Cytospora euonymicola on Euonymus kiautschovicus (BJFC-S1105). a-b. Habit of conidiomata on branch; c. transverse section through conidioma; d. Iongitudinal section through conidioma; e. conidiogenous cells with attached conidia; f. conidia. - Scale bars: $a=1 \mathrm{~mm} ; b-d=0.5 \mathrm{~mm} ; e-f=10 \mu \mathrm{m}$.
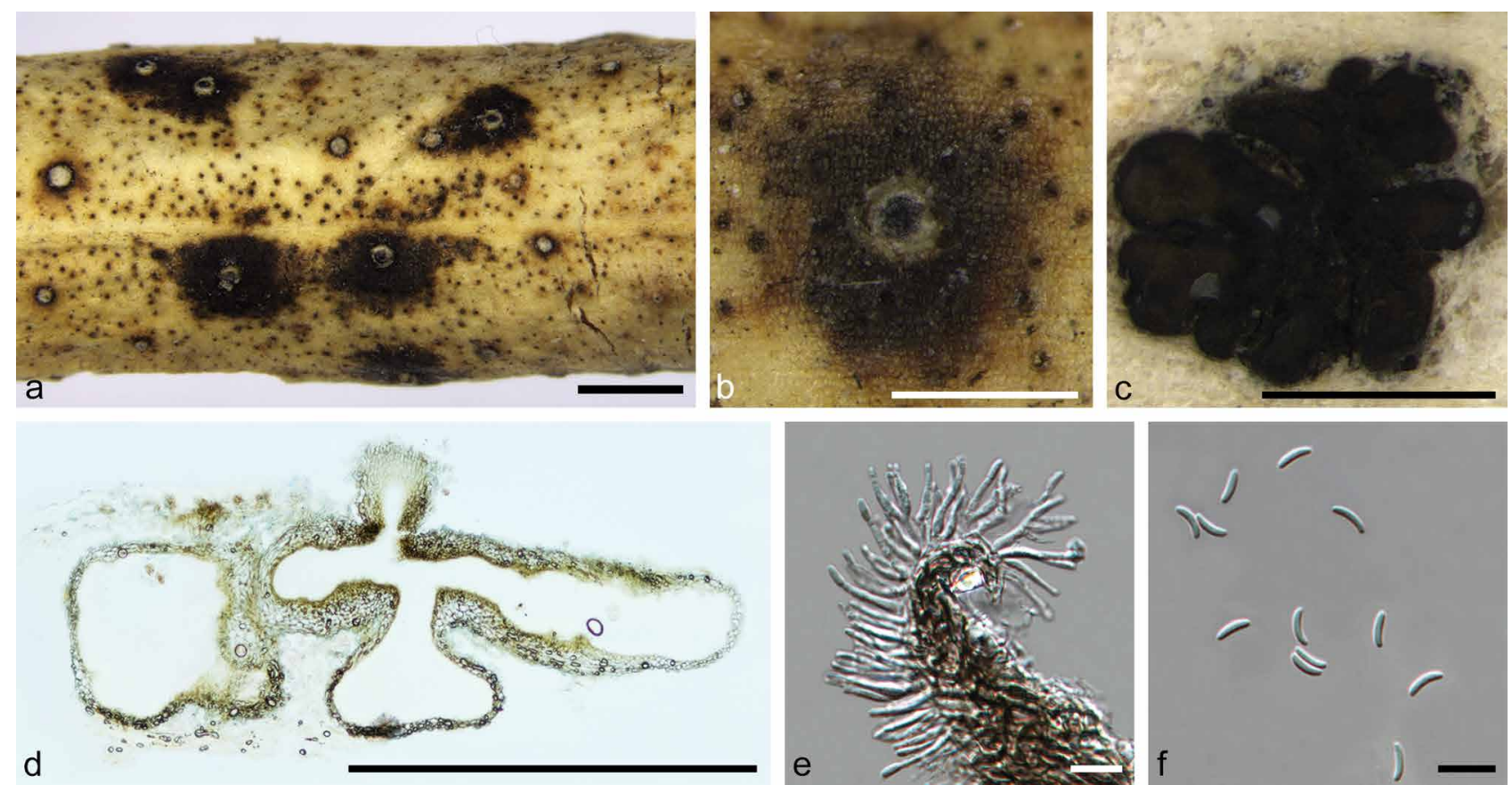

Fig. 18 Cytospora euonymina on Euonymus kiautschovicus (BJFC-S1025). a-b. Habit of conidiomata on branch; c. transverse section through conidioma; d. longitudinal section through conidioma; e. conidiogenous cells with attached conidia; f. conidia. - Scale bars: $a=1 \mathrm{~mm} ; b-d=0.5 \mathrm{~mm} ; e-f=10 \mu \mathrm{m}$.

matic disc honey to primrose, conspicuous, circular to ovoid, (135-)155-280(-310) $\mu \mathrm{m}$ diam, with 1-3 ostioles per disc. Ostiole in the centre or arranged regularly in the disc, violaceous black to black, conspicuous, (50-)60-140(-150) $\mu \mathrm{m}$ diam. Locules numerous, subdivided frequently by invaginations with independent walls, (800-)880-1100(-1250) $\mu \mathrm{m}$ diam. Conidiophores and conidiogenous cells inconspicuous. Conidia hyaline, allantoid, eguttulate, smooth, aseptate, thin-walled, $5-6(-6.5) \times 1-1.5 \mu \mathrm{m}$.

Material examined. CHINA, Yunan Province, Dali City, Binchuan County, Jizu Mountain, from branches of Cryptomeria japonica (as Cryptomeria fortunei), Nov. 1989, G.C. Zhao, S.F. Chen \& N. Li (holotype HSFC 15206, no living culture).

Notes - Cytospora fortunea is associated with canker disease of Cryptomeria japonica (as Cryptomeria fortunei) in China (Zhao et al. 1991). This species can be characterised by the multiple locules with independent walls from this host (Zhao et al. 1991). This species needs to be re-collected from Cryptomeria japonica in China, as presently no living culture is available.

Cytospora gigalocus C.M. Tian et al., Fungal Biol. 119: 313. 2015 - Fig. 20

Description - See Fan et al. (2015a).

Materials examined. CHINA, Qinghai Province, Xining City, Xishan Botanical Garden, N36 $37^{\prime} 25.89^{\prime \prime}$ E $101^{\circ} 44^{\prime} 48.92 "$, from twigs and branches of Juglans regia, 19 Aug. 2012, X.L. Fan (holotype BJFC-S647, ex-type living culture CFCC 89620); ibid., BJFC-S648, living culture CFCC 89621.

Notes - Cytospora gigalocus has multi-loculate conidiomata with one to five ostioles and shares common walls, and is morphologically similar to C. schulzeri from Malus spp. and C. carbonacea on Ulmus spp. (Mehrabi et al. 2011). Cytospora 
标本号 HSFC 15206

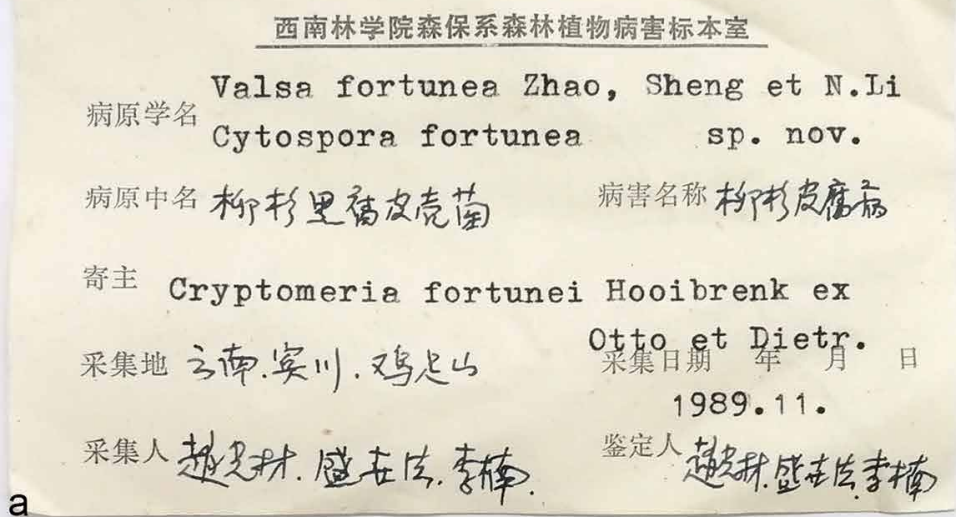
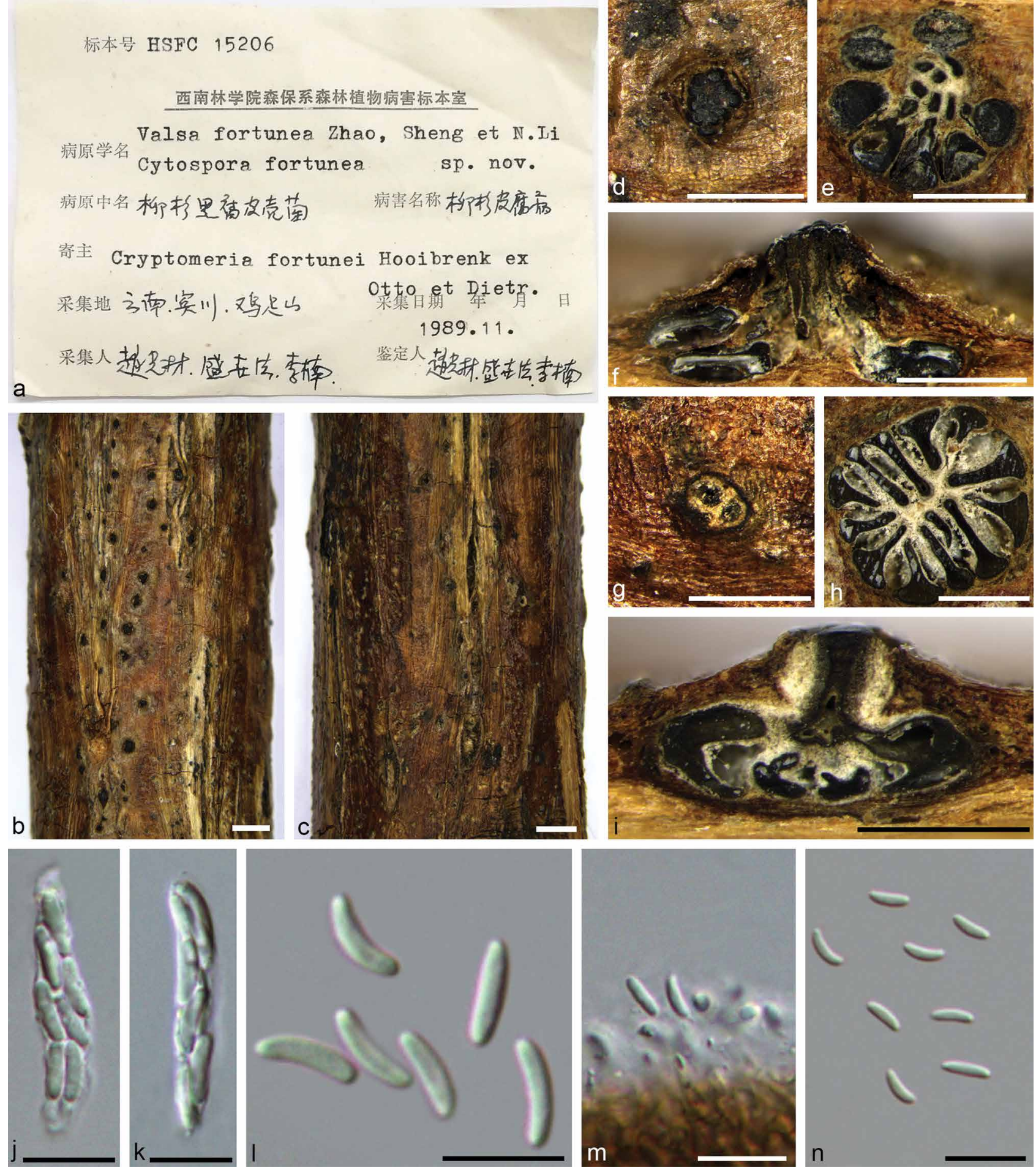

Fig. 19 Cytospora fortunea on Cryptomeria japonica (HSFC 15206). a, Herbarium material; b, d. habit of ascostromata on branch; c, g. habit of conidiomata on branch; e. transverse section through ascostroma; $f$. longitudinal section through ascostroma; $h$. transverse section through conidioma; $i$. longitudinal section through conidioma; $j-k$. asci; $I$. ascospores; $m-n$. conidia. - Scale bars: $b-c=1 \mathrm{~mm} ; \mathrm{d}-\mathrm{i}=0.5 \mathrm{~mm} ; \mathrm{j}-\mathrm{n}=10 \mu \mathrm{m}$.

gigalocus has larger locules with a central column as compared with C. schulzeri (1600-2200 vs $1400-1500 \mu \mathrm{m})$ diam, and it has smaller conidia than $C$. carbonacea $(4.8 \times 1.1$ vs $11.7 \times 1.7$ $\mu \mathrm{m})$ (Adams et al. 2006, Zhang et al. 2014, Fan et al. 2015a).

Cytospora gigaspora C.M. Tian et al., Phytotaxa 197: 232. 2015 - Fig. 21

Description - See Fan et al. (2015b).

Materials examined. CHINA, Shaanxi Province, Yulin City, Airport East Road, N38¹9'21.16" E109 $39^{\circ}{ }^{\prime} 54.73 "$ ", on twigs and branches of Salix psammophila, 1 Aug. 2013, X.L. Fan (holotype BJFC-S975, ex-type living culture
CFCC 89634); Shanxi Province, Datong, City, Wenying Ecological Garden, N40 $04^{\prime} 32.15^{\prime \prime} \mathrm{E} 113^{\circ} 21^{\prime} 55.18^{\prime \prime}$, on twigs and branches of Juniperus procumbens, 17 Apr. 2014, X.L. Fan (BJFC-S1045, living culture CFCC 50014).

Notes - Cytospora gigaspora has multi-loculate conidiomata with a single ostiole and black conceptacle, which is similar to C. nivea on Populus and Salix. However, C. gigaspora has unusually long conidia $(9-12 \times 2-3 \mu \mathrm{m})$ and flat locules compared to those of other Cytospora species. Cytospora chrysosperma, C. nivea and C. populina have previously been reported from Populus and Salix spp. as the causative agents of poplar and willow canker disease (Saccardo 1884, Teng 1963, Tai 1979, Wei 1979, Zhuang 2005, Fan et al. 2014b). 

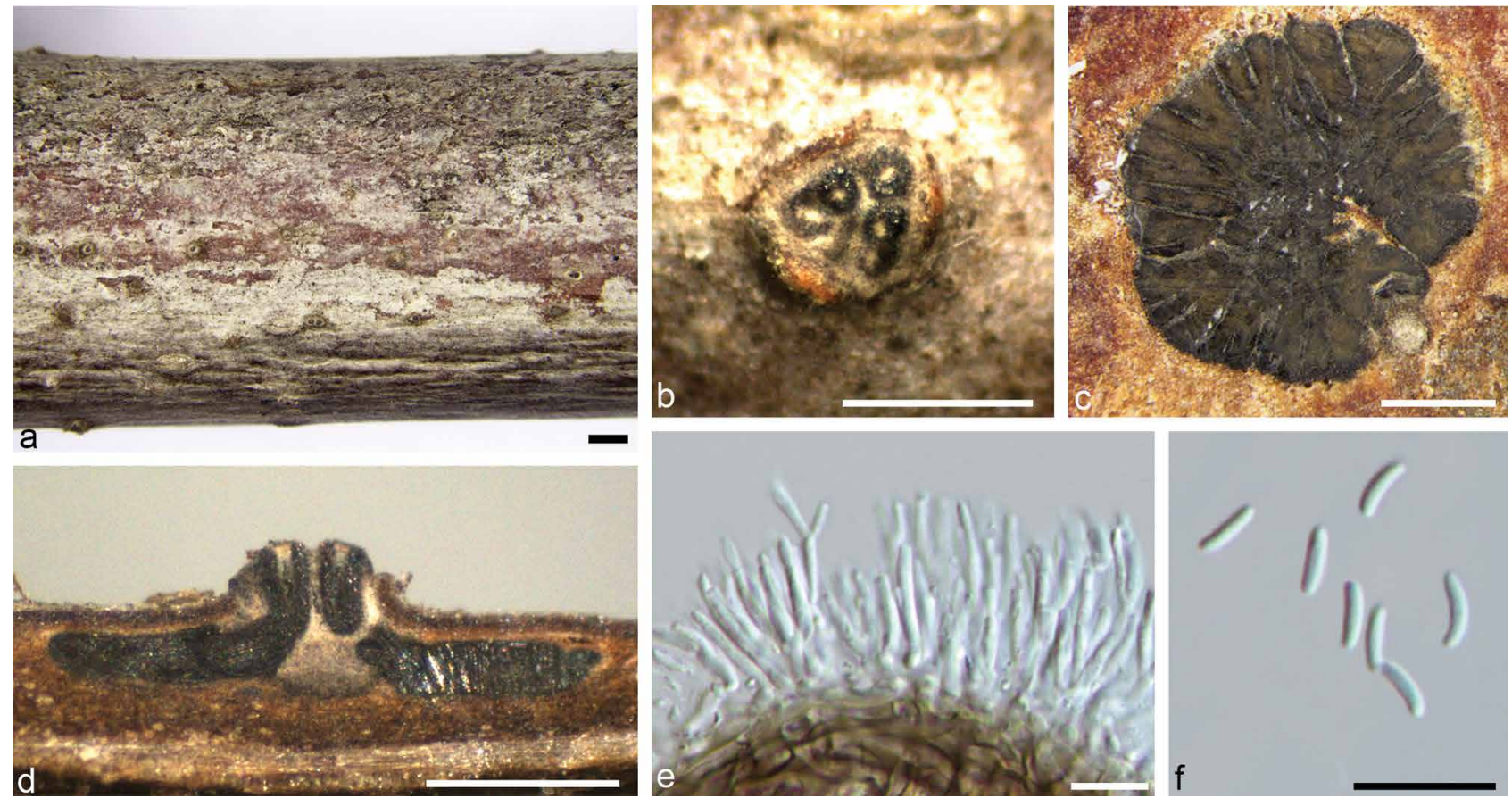

Fig. 20 Cytospora gigalocus on Juglans regia (BJFC-S647). a-b. Habit of conidiomata on branch; c. transverse section through conidioma; d. longitudinal section through conidioma; e. conidiogenous cells with attached conidia; f. conidia. - Scale bars: $a=1 \mathrm{~mm} ; b-d=0.5 \mathrm{~mm} ; e-f=10 \mu \mathrm{m}$.
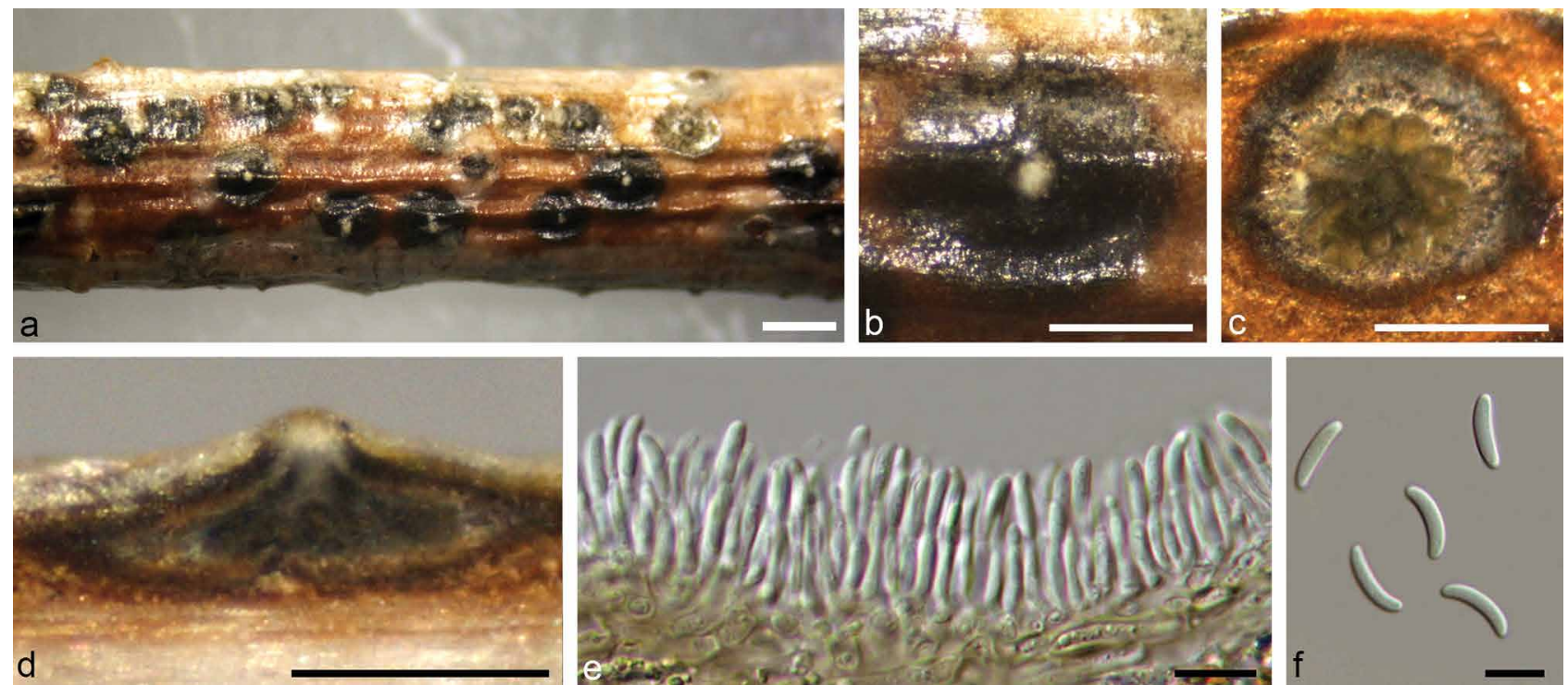

Fig. 21 Cytospora gigaspora on Salix psammophila (BJFC-S975). a-b. Habit of conidiomata on branch; c. transverse section through conidioma; d. longitudinal section through conidioma; e. conidiogenous cells with attached conidia; f. conidia. - Scale bars: $a=1 \mathrm{~mm} ; b-d=0.5 \mathrm{~mm} ; e-f=10 \mu \mathrm{m}$.

Cytospora hippophaës Thüm., Fungi Austria. Exsicc.: 282. 1872 - Fig. 22

Description - See Fan et al. (2015b).

Materials examined. CHINA, Gansu Province, Gannan City, Diebu County, N34 $02^{\prime} 06.70^{\prime \prime} \mathrm{E} 103^{\circ} 12^{\prime} 06.25^{\prime \prime}$, from twigs and branches of Hippophaë rhamnoides, 7 Aug. 2012, X.L. Fan (BJFC-S779, living culture CFCC 89639); ibid., living culture CFCC 89640.

Notes - Cytospora hippophaës is a common pathogen on Hippophaë rhamnoides in China (Zhuang 2005, Fan et al. $2015 \mathrm{~b})$. This species represents one of the members of Cytospora with host plant specificity, and it is mainly characterised by ascostromata extending to a large circular area with distinct large ectostromatic disc, and flat to discoid pycnidia with multiple ostioles on each ectostromatic disc.
Cytospora japonica (Miyabe \& Hemmi) X.L. Fan, comb. nov. — MycoBank MB830153; Fig. 23

Basionym. Valsa japonica Miyabe \& Hemmi, J. Coll. Agric., Imp. Univ. Sapporo 7(4): 296. 1917.

Sexual morph not observed. Pycnidial stromata ostiolate, immersed in bark, scattered, erumpent through the bark surface in a large circular area, discoid to conoid, with large multiple locules. Conceptacle black. Ectostromatic disc dark grey to black, conspicuous, circular to ovoid, (145-)160-440(-500) $\mu \mathrm{m}$ diam, with one ostiole per disc. Ostiole in the centre of the disc, inconspicuous, dark grey to black, (55-)60-125(-130) $\mu \mathrm{m}$ diam. Locules numerous, arranged circularly or irregularly with common walls, (750-)810-1150(-1200) $\mu \mathrm{m}$ diam. Conidiophores borne along the locules, hyaline, branched at the 

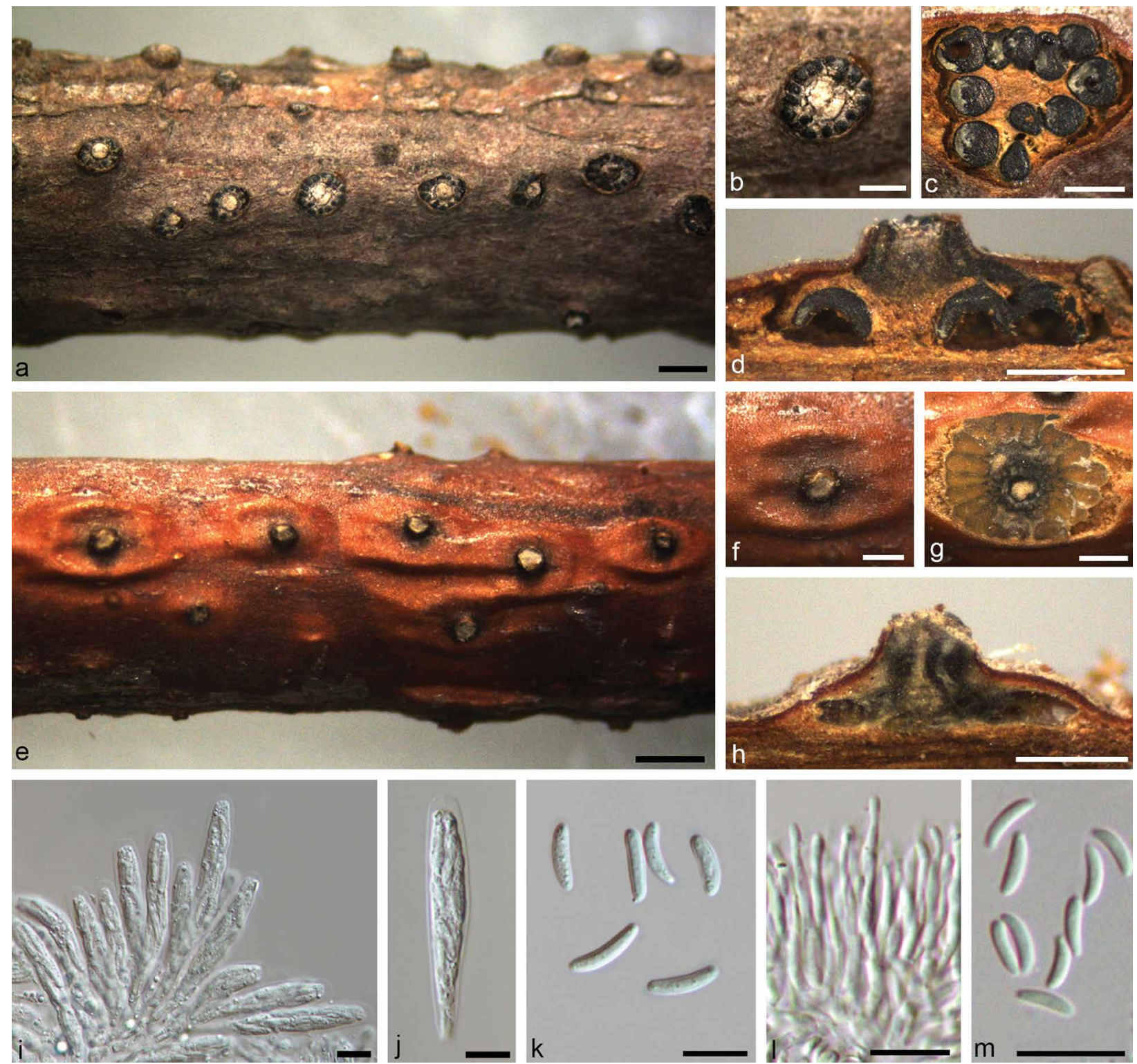

Fig. 22 Cytospora hippophaës on Hippophaë rhamnoides (BJFC-S779). a-b. Habit of ascostromata on branch; c. transverse section through ascostroma; d. longitudinal section through ascostroma; $e-f$. habit of conidiomata on branch; g. transverse section through conidioma; $h$. longitudinal section through conidioma; i-j. asci; $k$. ascospores; I. conidiogenous cells with attached conidia; $\mathrm{m}$. conidia. - Scale bars: $a, e=1 \mathrm{~mm} ; \mathrm{b}-\mathrm{d}, \mathrm{f}-\mathrm{h}=0.5 \mathrm{~mm} ; \mathrm{i}-\mathrm{m}=10 \mu \mathrm{m}$.
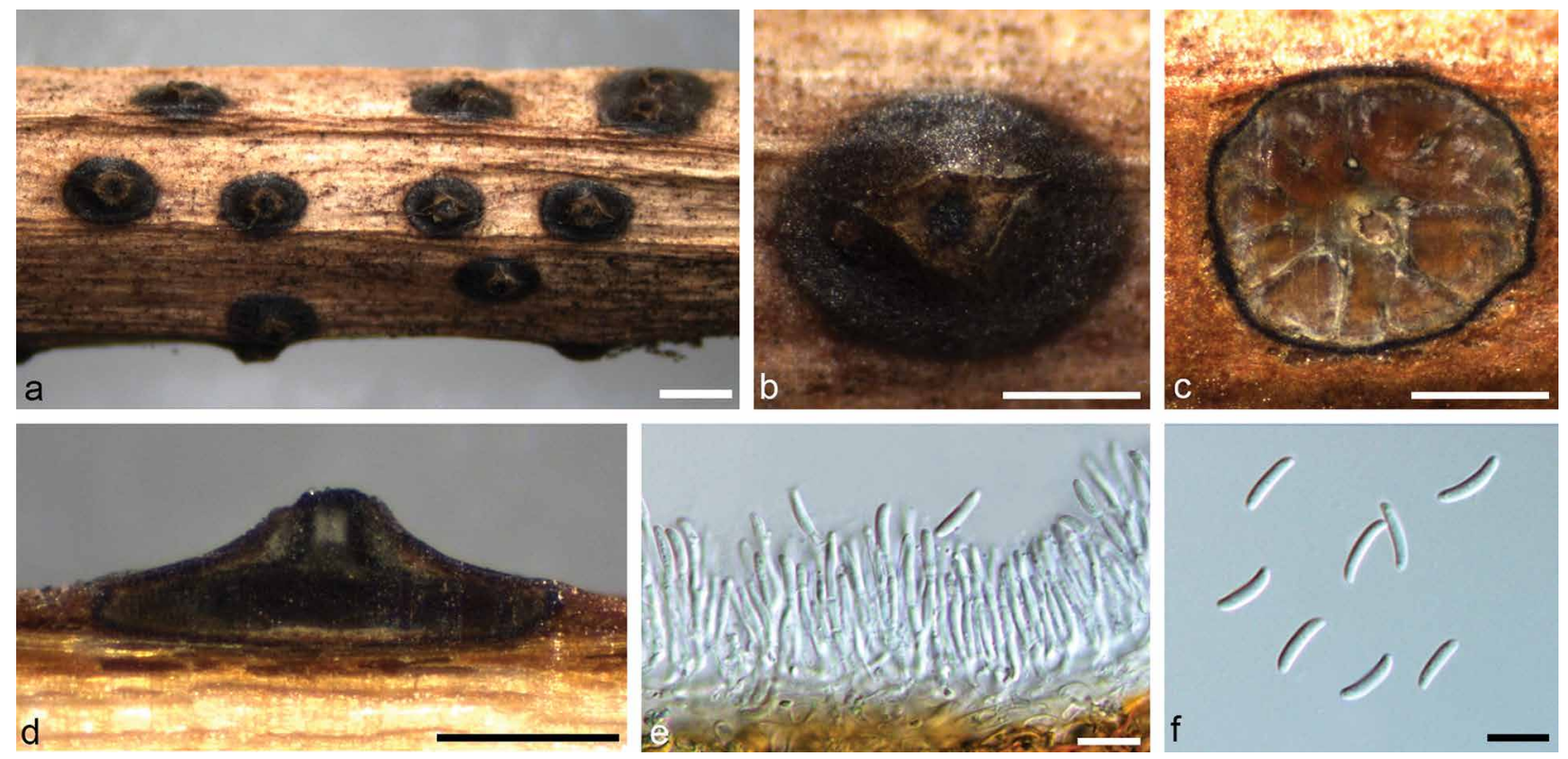

Fig. 23 Cytospora japonica on Prunus cerasifera f. atropurpurea (BJFC-S832). a-b. Habit of conidiomata on branch; c. transverse section through conidioma; d. longitudinal section through conidioma; e. conidiogenous cells with attached conidia; f. conidia. — Scale bars: $a=1 \mathrm{~mm} ; b-d=0.5 \mathrm{~mm} ; e-f=10 \mu \mathrm{m}$. 

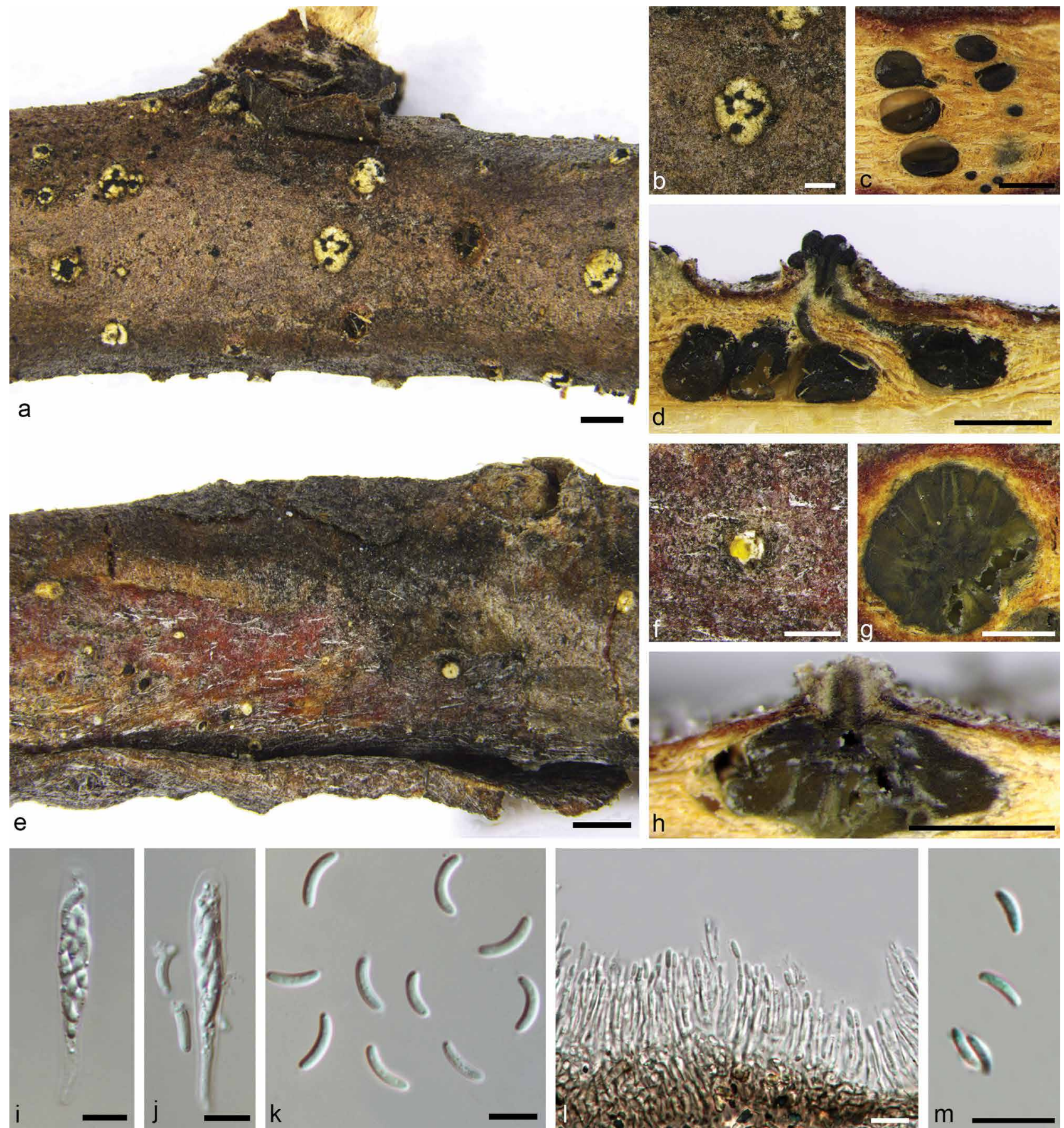

Fig. 24 Cytospora juniperina on Juniperus przewalskii (CF-2015410). a-b. Habit of ascostromata on branch; c. transverse section through ascostroma; $\mathrm{d}$. longitudinal section through ascostroma; $\mathrm{e}-\mathrm{f}$. habit of conidiomata on branch; $\mathrm{g}$. transverse section through conidioma; $\mathrm{h}$. longitudinal section through conidioma; i-j. asci; k. ascospores; I. conidiogenous cells with attached conidia; $\mathrm{m}$. conidia. - Scale bars: $\mathrm{a}, \mathrm{e}=1 \mathrm{~mm} ; \mathrm{b}-\mathrm{d}, \mathrm{f}-\mathrm{h}=0.5 \mathrm{~mm} ; \mathrm{i}-\mathrm{m}=10 \mu \mathrm{m}$.

base, in the middle, or unbranched, thin-walled, occasionally septate, $14.5-21 \times 1-1.5 \mu \mathrm{m}$, embedded in a gelatinous layer. Conidiogenous cells enteroblastic, phialidic, sub-cylindrical to cylindrical, $9-12.5 \times 1.5-2 \mu \mathrm{m}$, tapering towards the apices. Conidia hyaline, allantoid, eguttulate, smooth, aseptate, thinwalled, (5.5-)6.5-8.5(-9) × 1.5-2 $\mu \mathrm{m}$.

Culture characteristics - On PDA, colonies fast growing, up to $8 \mathrm{~cm}$ diam, white greyish, flat, spreading after $3 \mathrm{~d}$, reaching $9 \mathrm{~cm}$ diam after $4 \mathrm{~d}$, becoming white greyish to pale greyish after $30 \mathrm{~d}$. Pycnidia distributed concentrically on culture surface, extruding a hyaline to pale whitish conidial mass.

Materials examined. CHINA, Ningxia Province, Guyuan City, Jingyuan County, N35 ${ }^{\circ} 28^{\prime} 25.73^{\prime \prime} \mathrm{E} 106^{\circ} 22^{\prime} 10.06 "$ ", on twigs and branches of Prunus cerasifera, 22 July 2013, X.L. Fan (BJFC-S832, living culture CFCC 89956); ibid., living culture CFCC 89960.
Notes - Cytospora japonica is a common species infecting Rosaceae hosts in China (Tai 1979). It can be distinguished from C. leucostoma, another common pathogen of Prunoideae, by the larger size of its conidia $(6.5-8.5 \times 1.5-2$ vs $4.5-6 \times$ $1-1.5 \mu \mathrm{m})$ and colonies which tend to be white in culture.

Cytospora juniperina X.L. Fan \& C.M. Tian, sp. nov. - MycoBank MB830154; Fig. 24

Etymology. The name reflects the host genus from which it was collected, Juniperus.

Ascostromata immersed in the bark, erumpent through the bark surface, scattered, (1080-)1250-1600(-1740) $\mu \mathrm{m}$ diam, with 5-12 perithecia arranged circularly or irregularly. Conceptacle absent. Ectostromatic disc sulphur yellow to greyish sepia, usually surrounded by tightly ostiolar necks, circular, (200-) 
$220-350(-380) \mu \mathrm{m}$ diam. Ostioles numerous, dark brown to black, concentrated, arranged circularly in the disc, (45-)50.5$87(-95) \mu \mathrm{m}$ diam. Perithecia dark grey to black, flask-shaped to spherical, arranged circularly, (250-)320-480(-550) um diam. Asci free, clavate to elongate obovoid, (33-)35-45(-50) $\times$ (5-)5.5-6(-6.5) $\mu \mathrm{m}, 8$-spored. Ascospores biseriate, elongateallantoid, thin-walled, hyaline, aseptate, (9-)10-13.5(-14) $\times$ 3-3.5(-4) um. Pycnidial stromata ostiolate, immersed in bark, scattered, erumpent through the surface, with multiple locules. Conceptacle absent. Ectostromatic disc white to smoke grey, conspicuous, circular to ovoid, (210-)220-270(-305) $\mu \mathrm{m}$ diam, with one ostiole per disc. Ostiole in the centre of the disc, violaceous black to black, conspicuous, (42-)50-78(-80) $\mu \mathrm{m}$ diam. Locules numerous, subdivided frequently by invaginations with common walls, (980-)1120-1200(-1320) $\mu \mathrm{m}$ diam. Conidiophores borne along the locules, hyaline, branched at the base, in the middle, or unbranched, thin-walled, 14.5-20(-23) $\times 1-2 \mu \mathrm{m}$, embedded in a gelatinous layer. Conidiogenous cells enteroblastic, phialidic, sub-cylindrical to cylindrical, 5.5-11.5 $\times 1-1.5 \mu \mathrm{m}$, tapering towards the apices. Conidia hyaline, allantoid, eguttulate, smooth, aseptate, thin-walled, (5.5-)6-6.5 $\times 1-1.5 \mu \mathrm{m}$.

Culture characteristics - On PDA, colonies white, growing up to $3 \mathrm{~cm}$ diam after $3 \mathrm{~d}$, becoming buff with cinnamon on the margin, reaching $7 \mathrm{~cm}$ diam after $10 \mathrm{~d}$ and covering the entire $9 \mathrm{~cm}$ Petri dish after $14 \mathrm{~d}$. Colonies felt-like with a uniform texture. Pycnidia sparsely distributed over the medium surface.

Materials examined (all on twigs and branches of Juniperus przewalskii). CHINA, Sichuan Province, Aba City, Songtao County, Shuijing Town, N32 ${ }^{\circ} 54^{\prime} 32.60^{\prime \prime} \mathrm{E} 103^{\circ} 40^{\prime} 59.19^{\prime \prime}, 22$ Apr. 2015, X.L. Fan \& B. Cao (holotype CF-2015410, ex-type living culture CFCC 50501); ibid., CF-2015411, living culture CFCC 50502; Aba City, Songtao County, Shuijing Town, N3254'28.33" E10340'58.59", 23 Apr. 2015, X.L. Fan \& B. Cao (CF-2015412, living culture CFCC 50503).

Notes - Cytospora juniperina is associated with canker disease of Juniperus przewalskii in China, representing the first report of a Cytospora from this host. It is not common and easily diagnosed. It has a prominent white ectostromatic disc in symptomatic branches. It is also distinct based on sequence data and morphology.
Cytospora leucosperma (Pers.) Fr., Syst. Mycol. 2: 543.1823 - Fig. 25

Basionym. Naemaspora leucosperma Pers., Observ. Mycol. 1: 81. 1796. Synonyms. Sphaeria ambiens Pers., Syn. Meth. Fung. 1: 44. 1801. Valsa ambiens (Pers.) Fr., Summa Veg. Scand., Sectio Post. (Stockholm): 412. 1849

Cytospora ambiens Sacc., Michelia 1(5): 519. 1879.

Sexual morph not observed. Pycnidial stromata ostiolate, immersed in bark, scattered, erumpent through the bark surface, discoid, nearly flat, with multiple locules. Conceptacle absent. Ectostromatic disc prominent, flat, dark grey to black, circular to ovoid, (220-)270-370(-400) $\mu \mathrm{m}$ diam, with one ostiole per disc. Ostiole in the centre of the disc, conspicuous, dark grey to black, area below disc a lighter entostroma, (45-)55-100(-120) $\mu \mathrm{m}$ diam. Locules numerous, arranged circularly with common walls, (640-)720-980(-1030) $\mu \mathrm{m}$ diam. Conidiophores borne along the locules, hyaline, branched at the base, in the middle, or occasionally unbranched, thin-walled, $17-25 \times 2-2.5 \mu \mathrm{m}$, embedded in a gelatinous layer. Conidiogenous cells enteroblastic, phialidic, sub-cylindrical to cylindrical, 8-14.5 × 2-2.5 $\mu \mathrm{m}$, tapering towards the apices. Conidia hyaline, allantoid, eguttulate, smooth, aseptate, thin-walled, (3.5-)4-5(-5.5) × 1-1.5 $\mu \mathrm{m}$.

Culture characteristics - On PDA, colonies fast growing, up to $8 \mathrm{~cm}$ diam after $3 \mathrm{~d}$ and entire $9 \mathrm{~cm}$ Petri dish after $5 \mathrm{~d}$, white to light grey with a uniform texture, with an irregular margin, lacking aerial mycelium, becoming greyish and yellowish coloured after $30 \mathrm{~d}$. Pycnidia distributed irregularly on the medium surface.

Materials examined (all on twigs and branches of Pyrus bretschneideri). CHINA, Qinghai Province, Haidong City, Pingan County, E102 ${ }^{\circ} 09^{\prime} 18.38^{\prime \prime}$ N36²7'30.91", 15 Aug. 2012, X.L. Fan (BJFC-S618, living culture CFCC

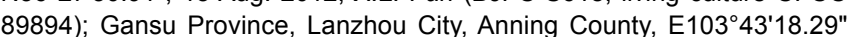
N3306'52.51", 13 Aug. 2012, X.L. Fan (BJFC-S772, living culture CFCC 89622).

Notes - Cytospora leucosperma (syn. Valsa ambiens) is the type species of the sexual genus Valsa, which was re-described by Adams et al. (2005). The asexual morph of $V$. ambiens has commonly been referred to as $C$. ambiens, but Spielman (1985) indicated that $C$. leucosperma is the earliest and correct name for this taxon. Cytospora leucosperma has a similar morphology and ITS phylogeny to that of Cytospora mali from Malus spp., leading to confusion in identifications (Wang et al. 2011).
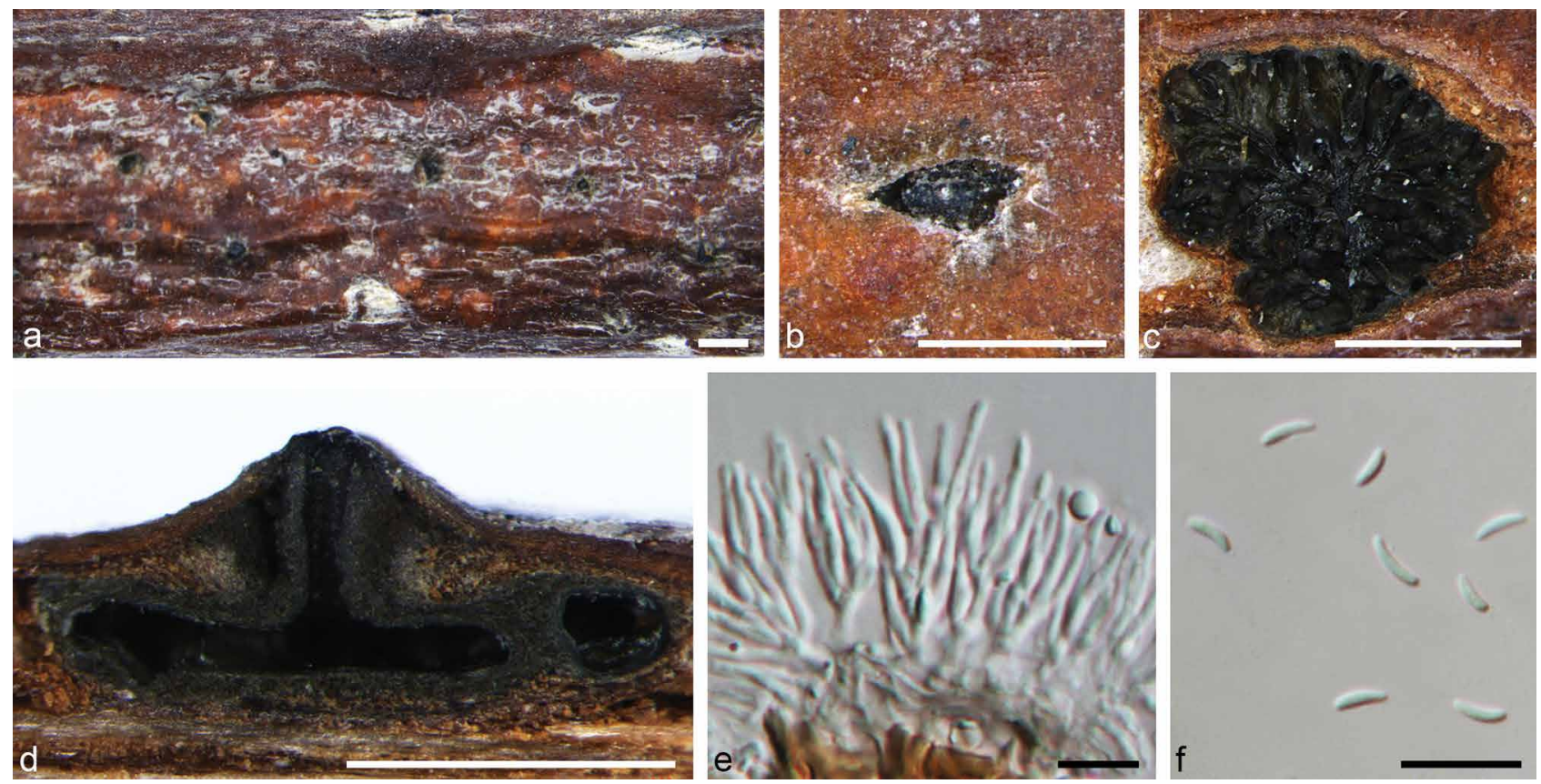

Fig. 25 Cytospora leucosperma on Pyrus sp. (BJFC-S618). a, b. Habit of conidiomata on branch; c. transverse section through conidioma; d. longitudinal section through conidioma; e. conidiogenous cells with attached conidia; f. conidia. - Scale bars: $a=1 \mathrm{~mm} ; b-d=0.5 \mathrm{~mm} ; \mathrm{e}-\mathrm{f}=10 \mu \mathrm{m}$. 

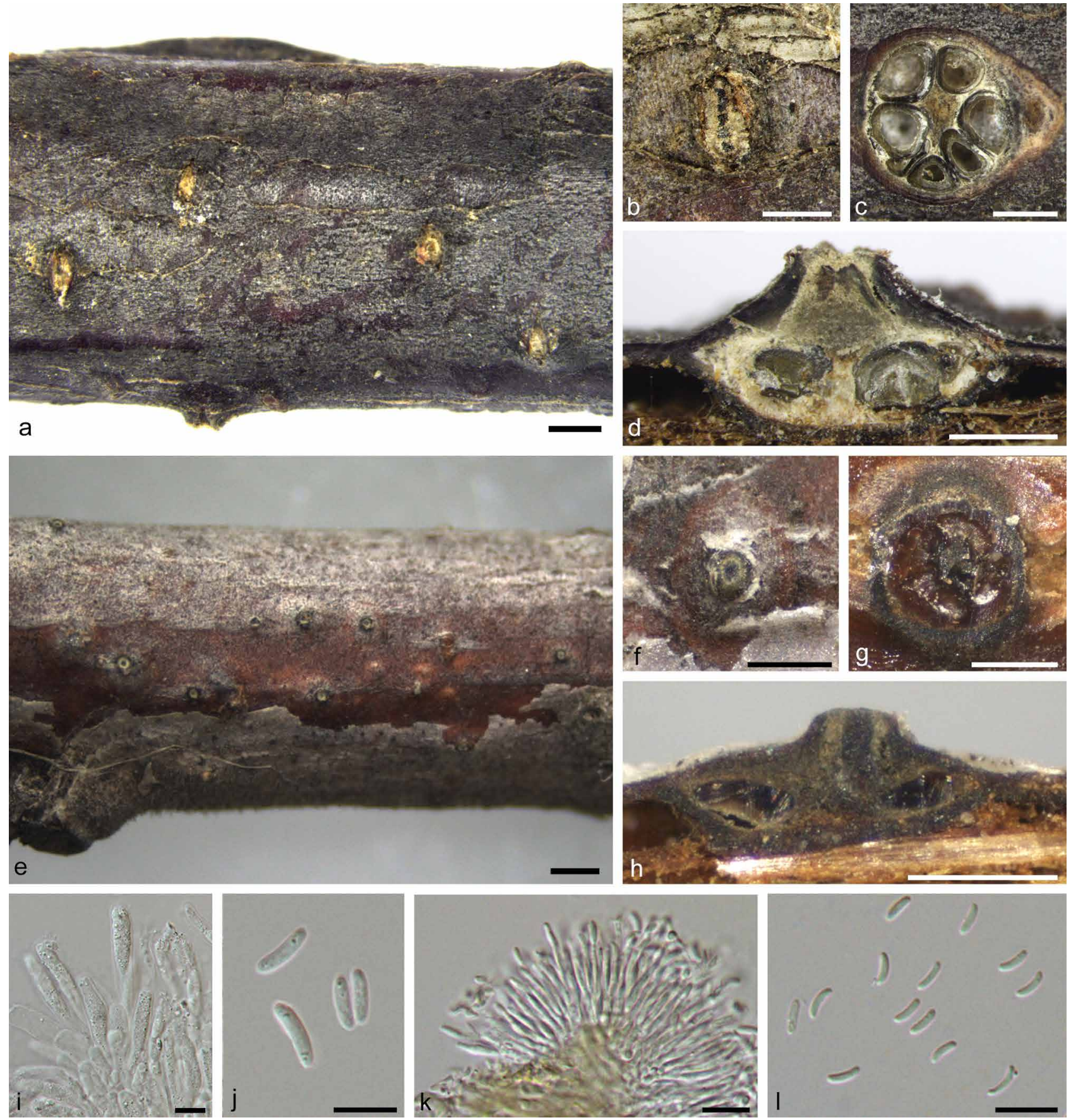

Fig. 26 Cytospora leucostoma on Prunus persica (BJFC-S918). a-b. Habit of ascostromata on branch; c. transverse section through ascostroma; d. longitudinal section through ascostroma; $\mathrm{e}-\mathrm{f}$. habit of conidiomata on branch; $\mathrm{g}$. transverse section through conidioma; $\mathrm{h}$. longitudinal section through conidioma; i. asci; j. ascospores; $k$. conidiogenous cells with attached conidia; I. conidia. - Scale bars: $a, e=1 \mathrm{~mm} ; \mathrm{b}-\mathrm{d}, \mathrm{f}-\mathrm{h}=0.5 \mathrm{~mm} ; \mathrm{i}-\mathrm{I}=10 \mu \mathrm{m}$.

Cytospora leucosperma was chiefly isolated and recorded from infected Pyrus spp. in China (Teng 1963, Tai 1979, Zhuang 2005). Urban (1957) and Spielman (1985) designated PR 163781 from Tilia as neotype, but without any available living culture or DNA sequence data. Thus, the current identification is provisional and must await further studies of European material from the type host.

Cytospora leucostoma (Pers.) Sacc., Michelia 2: 264. 1881 Fig. 26

Synonyms. Sphaeria leucostoma Pers., Ann. Bot. 11: 23. 1794. Valsa leucostoma (Pers.) Fr., Summa Veg. Scand., Section Post. (Stockholm): 411. 1849.

Valsa persoonii Nitschke, Pyrenomyc. Germ. 2: 222. 1870.

Leucostoma persoonii (Nitschke) Höhn., Mitt. Bot. Inst. Tech. Hochsch. Wien 5: 78. 1928.

Cytospora donetzica Norph. et al., Mycosphere 8: 62. 2017.
Ascostromata immersed in the bark, erumpent through the bark surface, scattered, (850-)1000-1500(-1600) $\mu \mathrm{m}$ diam, with 2-10 perithecia arranged circularly or irregularly. Conceptacle black. Ectostromatic disc conspicuous, circular, (200-)250$300(-350) \mu \mathrm{m}$ diam, occasionally fusiform, with ostiolar necks, up to (600-)650-800(-900) $\mu \mathrm{m}$ diam, with 2-10 ostioles in disc. Ostioles numerous, violaceous black to black, concentrated, arranged straight or circular in the disc, (60-)70-100(-115) $\mu \mathrm{m}$ diam. Perithecia dark grey to fuscous black, flask-shaped to spherical, arranged circularly or irregularly, (300-)350-550 $(-600) \mu \mathrm{m}$ diam. Asci free, clavate to elongate obovoid, (35-)40$50(-55) \times(6.5-) 7-8(-8.5) \mu \mathrm{m}, 8$-spored. Ascospores biseriate, elongate-allantoid, thin-walled, hyaline, aseptate, (8.5-)9-11($11.5) \times 2.5-3 \mu \mathrm{m}$. Pycnidial stromata ostiolate, immersed in bark, scattered, erumpent through the surface, with multiple locules. Conceptacle black. Ectostromatic disc straw to honey, conspicuous, circular to ovoid, (100-)120-170(-200) $\mu \mathrm{m}$ diam, 
with one ostiole per disc. Ostiole in the centre, violaceous black to black, conspicuous, (40-)50-100(-115) $\mu \mathrm{m}$ diam. Locules numerous, subdivided frequently by invaginations with independent walls, (600-)650-1100(-1300) $\mu \mathrm{m}$ diam. Conidiophores borne along the locules, hyaline, branched at the base, in the middle, or occasionally unbranched, thin-walled, 11-21 $x$ $1-1.5 \mu \mathrm{m}$, embedded in a gelatinous layer. Conidiogenous cells enteroblastic, phialidic, sub-cylindrical to cylindrical, 10.5-16 $\times 1-1.5 \mu \mathrm{m}$, tapering towards the apices. Conidia hyaline, allantoid, eguttulate, smooth, aseptate, thin-walled, 4.5-5.5 $\times$ $1-1.5 \mu \mathrm{m}$.

Culture characteristics - On PDA, colonies initially white to grey with a dark grey colour in the centre, growing up to $8 \mathrm{~cm}$ diam after $3 \mathrm{~d}$, secreting a dark green to black pigment in culture medium after 7-10 d. Colonies dark grey to black, flat, felt-like after $30 \mathrm{~d}$. Pycnidia irregularly distributed on the medium surface.

Materials examined. CHINA, Shanxi Province, Changzhi City, Taihang Park, E13 ${ }^{\circ} 06^{\prime} 30.25^{\prime \prime} \mathrm{N} 36^{\circ} 12^{\prime} 07.48^{\prime \prime}$, on branches of Cornus alba, $20 \mathrm{Apr}$. 2014, X.L. Fan \& B. Cao (BJFC-S1030, living culture CFCC 50023); Gansu Province, Tianshui City, Xiaolong Mountain, E106¹1'23.59" N3441'39.25", on branches of Rosa helenae, 16 July 2013, X.L. Fan (BJFC-S875, living culture CFCC 50019); Tianshui City, Manji Town, E10557'49.94" N34²5'28.67", on branches of Prunus serrulata, 18 July 2013, X.L. Fan (BJFC-S847, living culture CFCC 50018); Qingyang City, Heshui County, E107²59'37.03" N35 47'04.66", on branches of Prunus persica, 13 July 2013, X.L. Fan (BJFC-S918, living culture CFCC 50020); Qingyang City, Heshui County, E107'59'38.71" N3547'04.43", on branches of Prunus salicina, 13 July 2013, X.L. Fan (BJFC-S933, living culture CFCC 50021); Beijing City, Tongzhou District, Song Village, E116 $39^{\prime} 32^{\prime \prime}$ N3959'49", on branches of Betula platyphylla, 20 Mar. 2015, X.L. Fan (BJFC-S1315, living culture CFCC 50467); ibid., BJFC-S1316, living culture CFCC 50468; Qinghai Province, Haidong City, Ledu District, Zhanbo Town, E102 ${ }^{\circ} 27^{\prime} 00.56^{\prime \prime}$ N36²7'51.13", on branches of Prunus pseudocerasus, 14 Aug. 2012, X.L. Fan (BJFC-S605, living culture CFCC 50024); Ningxia Province, Guyuan City, The Great Wall Beam, E106 $14^{\prime} 21.13^{\prime \prime}$ N3602'13.51", on branches of Prunus cerasifera, 24 July 2013, X.L. Fan (BJFC-S823, living culture CFCC 50017); Guyuan City, Jingyuan County, Liupan Mountain, E106 ${ }^{\circ} 23^{\prime} 12.05^{\prime \prime}$ N35 ${ }^{\circ} 23^{\prime} 58.30^{\prime \prime}$, on branches of Sorbus aucuparia, 23 July 2013, X.L. Fan (BJFC-S805, living culture CFCC 50015); Guyuan City, Jingyuan County, Liupan Mountain, Nanzhuang Town, E106²3'32.20" N35²3'48.77", on branches of Sorbus aucuparia, 22 July 2013, X.L. Fan (BJFC-S819, living culture CFCC 50016).

Notes - Cytospora leucostoma is a common species causing canker disease of Rosaceae hosts, especially Prunoideae
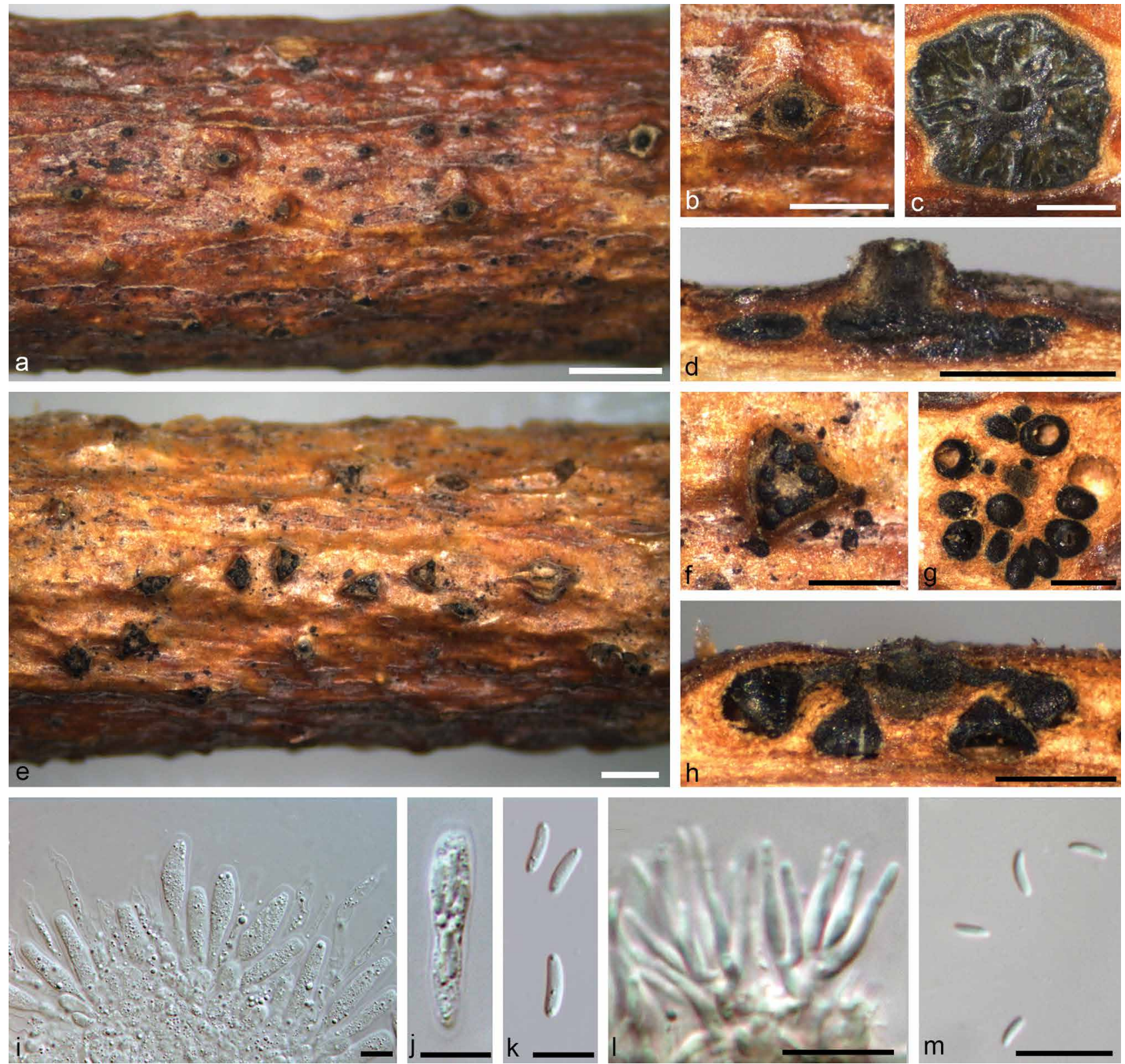

Fig. 27 Cytospora mali on Malus pumila (BJFC-S503). a-b. Habit of ascostromata on branch; c. transverse section through ascostroma; d. longitudinal section through ascostroma; $\mathrm{e}-\mathrm{f}$. habit of conidiomata on branch; g. transverse section through conidioma; $\mathrm{h}$. longitudinal section through conidioma; $\mathrm{i}-\mathrm{j}$. asci; k. ascospores; I. conidiogenous cells with attached conidia; $\mathrm{m}$. conidia. - Scale bars: $a, e=1 \mathrm{~mm} ; \mathrm{b}-\mathrm{d}, \mathrm{f}-\mathrm{h}=0.5 \mathrm{~mm} ; \mathrm{i}-\mathrm{m}=10 \mu \mathrm{m}$. 
in China (Teng 1963, Tai 1979, Wei 1979, Zhuang 2005). This species is similar to $C$. japonica and $C$. nivea, of which the former can be distinguished by its smaller conidia (4.5-6 × 1-1.5 vs $6.5-8.5 \times 1.5-2 \mu \mathrm{m})$ and white colonies in culture. Cytospora nivea differs from $C$. leucostoma based on its distinct host associations (Populus and Salix), as well as DNA sequence data (Fan et al. 2014b). Based on currently available DNA data (Fig. $3,4)$ and descriptions, Cytospora donetzica should be treated as synonym of $C$. leucostoma.

Cytospora mali Grove, British Stem- and Leaf-Fungi (Coelomycetes) (Cambridge) 1: 279. 1935 - Fig. 27

Synonym. Valsa mali Miyabe \& G. Yamada, M. Miura Agr. Exp. Stn Bull. 4: 17.1915

Ascostromata immersed in the bark, erumpent through the bark surface, scattered, (1080-)1260-1660(-1780) $\mu \mathrm{m}$ diam, with 8-16 perithecia arranged circularly. Conceptacle absent. Ectostromatic disc light brown to grey, usually surrounded by tightly ostiolar necks, flat, circular to ovoid, (450-)510-660(-710) $\mu \mathrm{m}$ diam, with 8-16 ostioles arranged circularly or triangularly per disc. Ostioles grey to black, concentrated, dark brown to black, arranged circularly in a disc, (85-)96.5-154(-172) $\mu \mathrm{m}$ diam. Perithecia dark brown, flask-shaped to spherical, arranged irregularly, (260-)280-380(-450) $\mu \mathrm{m}$ diam. Asci free, clavate to elongate obovoid, (22.5-)25.5-33.5(-40) $\times(4-) 4.5-6 \mu \mathrm{m}$, 8-spored. Ascospores biseriate, elongate-allantoid, thin-walled, hyaline, aseptate, $(6-) 6.5-10(-11) \times 1-1.5 \mu \mathrm{m}$. Pycnidial stromata ostiolate, immersed in bark, scattered, erumpent through the bark surface, discoid, with multiple locules. Conceptacle absent. Ectostromatic disc dark grey to black, circular to ovoid, (280-)300-480(-510) $\mu \mathrm{m}$ diam, with one ostiole per disc. Ostiole in the centre of the disc, conspicuous, black, (40-)54102(-125) $\mu \mathrm{m}$ diam. Locules numerous, arranged irregularly with common walls, (600-)630-890(-950) $\mu \mathrm{m}$ diam. Conidiophores hyaline, branched at the base, in the middle, or occasionally unbranched, thin-walled, 7.5-15(-16.5) $\times 1.5$ $\mu \mathrm{m}$, embedded in a gelatinous layer. Conidiogenous cells enteroblastic, phialidic, sub-cylindrical to cylindrical, 8-11.5 $\times 1.5-2 \mu \mathrm{m}$, tapering towards the apices. Conidia hyaline, allantoid, eguttulate, smooth, aseptate, thin-walled, 4-5(-5.5) $\times 1(-1.5) \mu \mathrm{m}$.

Culture characteristics - On PDA, colonies grey to pale greenish grey, with a dark grey colour in the centre, fast growing, reaching up to $7 \mathrm{~cm}$ diam after $3 \mathrm{~d}$ and entirely covering the $9 \mathrm{~cm}$ Petri dish after $5 \mathrm{~d}$, becoming grey to dark grey, flat, thick, felt-like after $30 \mathrm{~d}$. Pycnidia sparse, irregularly distributed on the culture medium surface.

Materials examined. CHINA, Gansu Province, Gannan City, Diebu County,

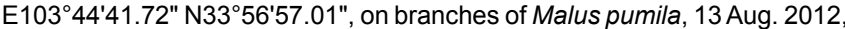
X.L. Fan (BJFC-S767, living culture CFCC 50028); Ningxia Province, Yinchuan City, E106 $03^{\prime} 07.12^{\prime \prime} \mathrm{N} 38^{\circ} 28^{\prime} 26.70^{\prime \prime}$, on branches of Malus pumila,
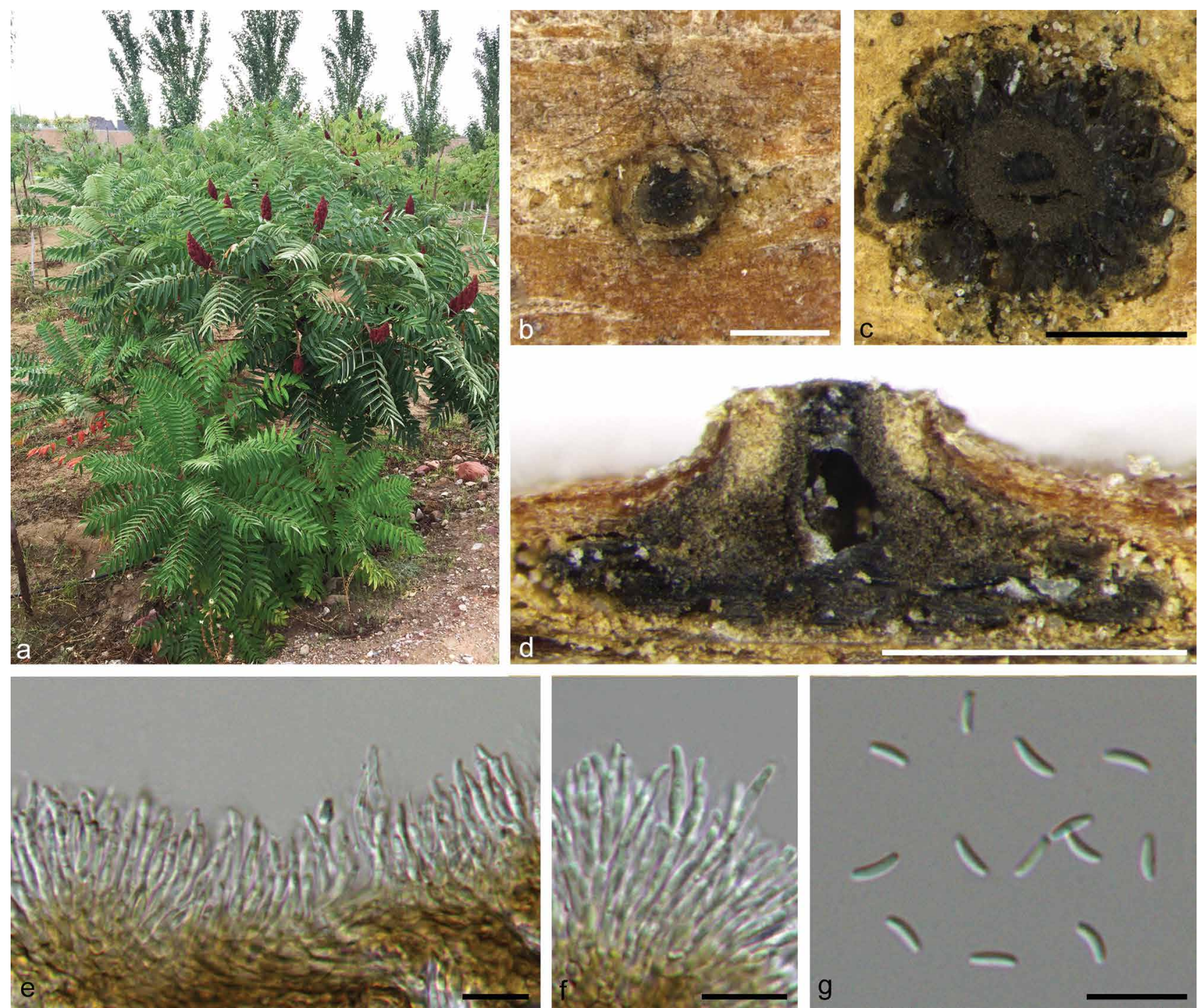

Fig. 28 Cytospora melnikii on Rhus typhina (BJFC-XJHJS). a. Host; b. habit of conidioma on branch; c. transverse section through conidioma; d. longitudinal section through conidioma; $e-f$. conidiogenous cells with attached conidia; $g$. conidia. - Scale bars: $a=1 \mathrm{~mm} ; b-d=0.5 \mathrm{~mm} ; e-g=10 \mu \mathrm{m}$. 
7 Feb. 2012, X.L. Fan (BJFC-S503, living culture CFCC 50029); Shaanxi Province, Yangling District, E108 $00^{\prime} 49.89^{\prime \prime} \mathrm{N} 34^{\circ} 14^{\prime} 01.93^{\prime \prime}$, on branches of Malus pumila, 30 Mar. 2012, X.L. Fan (BJFC-S740, living culture CFCC 50030); Shanxi Province, Taiyuan City, E112 $311^{\prime} 51.07^{\prime \prime}$ N37 $54^{\circ} 28.11^{\prime \prime}$, on branches of Crataegus pinnatifida, 16 Apr. 2014, X.L. Fan \& B. Cao (BJFCS1066, living culture CFCC 50031); Qinghai Province, Xining City, Xishan botanical garden, E102 $09^{\prime} 16.90^{\prime \prime} \mathrm{N} 36^{\circ} 27^{\prime} 32.44^{\prime \prime}$, on branches of Malus baccata, 19 Aug. 2012, X.L. Fan (BJFC-S691, living culture CFCC 50044).

Notes - Cytospora mali is a common species causing canker disease of Maloideae hosts, especially apple (Teng 1963, Tai 1979, Wei 1979, Zhuang 2005, Wang et al. 2011). This species is similar to $C$. leucosperma from Pyrus spp. in morphology, which is regarded as a sister clade in phylogeny. However, C. mali is mostly recorded from Malus spp.

Cytospora melnikii Norph. et al., Mycosphere 8: 68. 2017 Fig. 28

Description - Norphanphoun et al. (2017).

Material examined. CHINA, Xinjiang Province, Urumchi City, Anningqu nursery, N87 $52^{\prime} 19.24^{\prime \prime} \mathrm{E} 43^{\circ} 58^{\prime} 59.50^{\prime \prime}$, on branches of Rhus typhina, X.L. Fan (BJFC-XJHJS, living culture CFCC 89984).

Notes - Cytospora melnikii is associated with canker disease of Malus domestica and Populus nigra in Russia (Norphanphoun et al. 2017). This species is similar to the type species C. chrysosperma, but they are distinguished as separate taxa in the multigene analyses (Fig. 4). The current study represents the first report of this species from China.

Cytospora nivea (Hoffm.) Sacc., Michelia 2: 264. 1881 - Fig. 29

Basionym. Sphaeria nivea Hoffm., Veg. Crypt. 1: 28. 1787.

Synonyms. Leucostoma niveum (Hoffm.) Höhn., Mitt. Bot. Inst. Tech. Hochsch. Wien 5: 58. 1928.

Valsa nivea (Hoffm.) Fr., Summa Veg. Scand., Section Post. (Stockholm): 411. 1849 .

Sexual morph not observed. Pycnidial stromata immersed in bark, erumpent through the bark surface, releasing the red gelatinous conidial tendrils when moist, discoid to conicoid, with multiple locules. Conceptacle black. Ectostromatic disc brown to dark grey, nearly flat, ovoid to ellipsoid, (110-)140-210(-270) $\mu \mathrm{m}$ diam, with one ostiole per disc. Ostiole dark grey to black, conspicuous, 52.5-93 $\mu \mathrm{m}$ diam. Locules numerous, arranged irregularly with common walls, (410-)470-650(-770) $\mu \mathrm{m}$ diam. Conidiophores borne along the locules, hyaline, unbranched, or occasionally branched at the base, $17-25.5(-27) \times 1.5-2 \mu \mathrm{m}$, embedded in a gelatinous layer. Conidiogenous cells enteroblastic, phialidic, sub-cylindrical to cylindrical, 7-22 × 1.5-2 $\mu \mathrm{m}$, tapering towards the apices. Conidia hyaline, allantoid, guttulate, smooth, aseptate, thin-walled, $6-9(-10) \times 1.5-2.5(-3) \mu \mathrm{m}$.
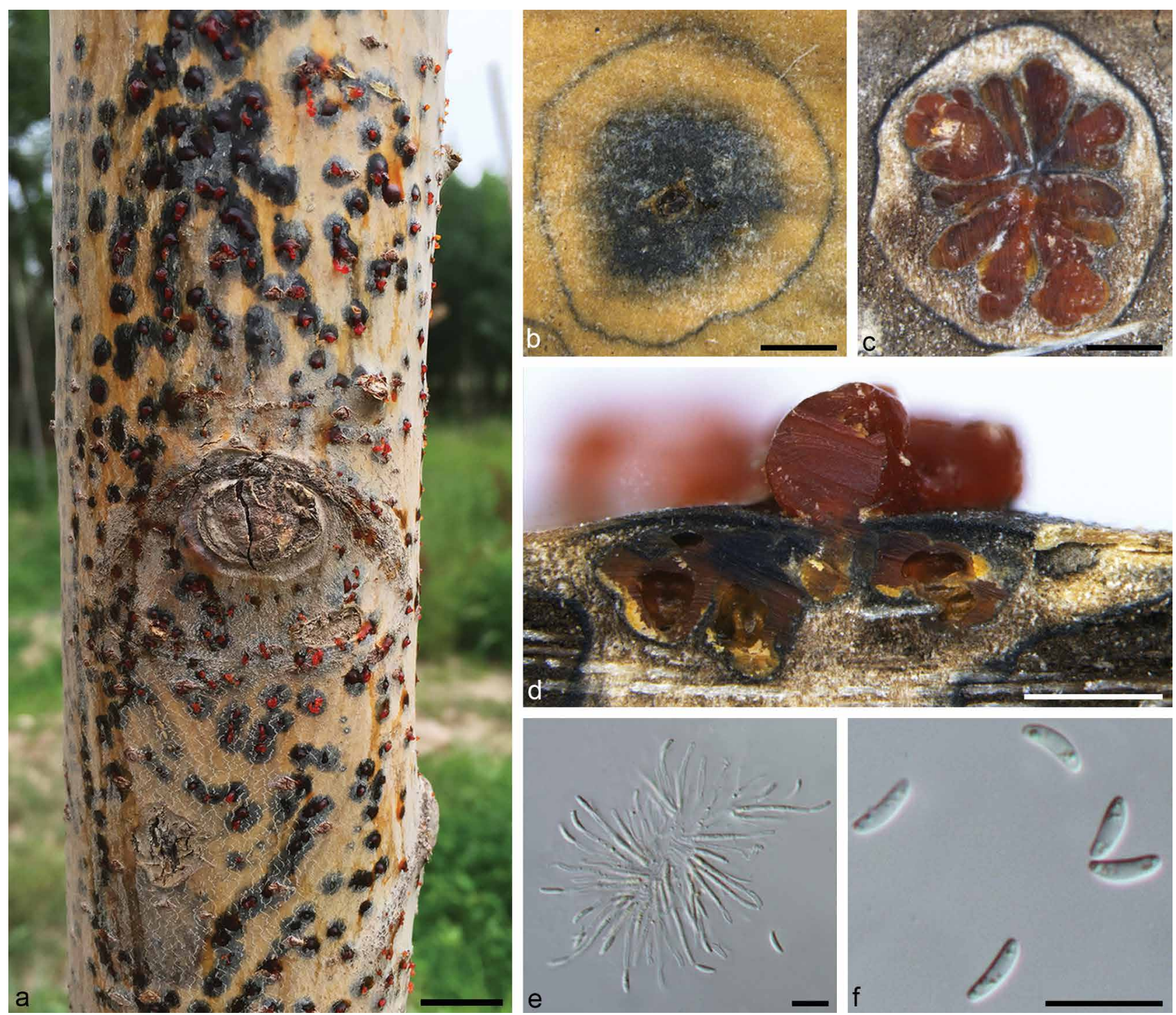

Fig. 29 Cytospora nivea on Populus alba subsp. pyramidalis (BJFC-S1307). a. Disease symptoms; b. habit of conidiomata on branch; c. transverse section through conidioma; $d$. longitudinal section through conidioma; e. conidiogenous cells with attached conidia; $f$. conidia. $-\mathrm{Scale}$ bars: $a=5 \mathrm{~mm} ; \mathrm{b}-\mathrm{d}=0.5$ $\mathrm{mm} ; \mathrm{e}-\mathrm{f}=10 \mu \mathrm{m}$. 
Culture characteristics - On PDA, colonies initially white to greyish, secreting a greenish olivaceous to olivaceous pigment, fast growing, entirely covering the $9 \mathrm{~cm}$ Petri dish after $3 \mathrm{~d}$, becoming olivaceous grey to olivaceous black, flat, felt-like after $30 \mathrm{~d}$. Pycnidia sparsely distributed on the culture medium.

Materials examined. CHINA, Ningxia Province, Guyuan City, Changchengliang, N36 $03^{\circ} 01.78^{\prime \prime} \mathrm{E} 106^{\circ} 16^{\prime} 18.09^{\prime \prime}$, on twigs and branches of Elaeagnus angustifolia, 24 July 2013, X.L. Fan (BJFC-S964, living culture CFCC 89641); Shaanxi Province, Yulin City, Hongshi Gorge, N38¹9'32.43" E10942'00.69", on twigs and branches of Salix psammophila, 29 July 2013, X.L. Fan (BJFCS979, living culture CFCC 89643).

Notes - Cytospora nivea is a commonly recorded species associated with Salicaceae hosts and commonly co-occurring with C. chrysosperma, which was regarded as the most common causative agent of poplar and willow canker disease in China (Saccardo 1881, 1884, Zhuang 2005, Fan et al. 2014b). Cytospora nivea can be distinguished from C. chrysosperma based on its black conceptacle surrounding the sexual and asexual stroma, usually presenting a huge black ectostromatic disc on the bark surface (Adams et al. 2005, Fan et al. 2014b).

Cytospora platycladiX.L. Fan \& C.M. Tian, sp. nov. - MycoBank MB830155; Fig. 30

Etymology. The name reflects the host genus from which it was collected, Platycladus.

Sexual morph not observed. Pycnidial stromata ostiolate, immersed in bark, scattered, erumpent through the surface, with multiple locules. Conceptacle absent. Ectostromatic disc dark grey to black, conspicuous, circular to ovoid, (210-)230-300 $(-330) \mu \mathrm{m}$ diam, with one ostiole per disc. Ostiole in the centre of the disc, black, conspicuous, (40-)45-75(-85) $\mu \mathrm{m}$ diam. Locules numerous, arranged circularly or elliptically with independent walls, (750-)820-1370(-1520) $\mu \mathrm{m}$ diam. Conidiophores borne along the locules, hyaline, branched at the base, in the middle, or occasionally unbranched, thin-walled, 11-18 $\times 1-1.5 \mu \mathrm{m}$, embedded in a gelatinous layer. Conidiogenous cells enteroblastic, phialidic, sub-cylindrical to cylindrical, 5-12 $\times 1-1.5 \mu \mathrm{m}$, tapering towards the apices. Conidia hyaline, allantoid, guttulate, smooth, aseptate, thin-walled, (4-)4.5-5(-5.5) $\times 1-1.5 \mu \mathrm{m}$.

Culture characteristics - On PDA, colonies initially white, growing fast, entirely covering the $9 \mathrm{~cm}$ Petri dish after $4 \mathrm{~d}$, becoming leaden grey after 7-10 d, becoming flat, felt-like, and thin with a uniform texture and aerial mycelium after $30 \mathrm{~d}$. Pycnidia sparse, concentrically and irregularly distributed on the medium surface.

Materials examined. CHINA, Yunnan Province, Chuxiong City, Elu Park, N25 01 '38.43" E101'32'12.44", on branches of Platycladus orientalis, 19 Mar. 2015, X.L. Fan, B. Cao, Q. Yang \& Z. Du (holotype BJFC-S1111, ex-type living culture CFCC 50504); ibid., living culture CFCC 50505; Chuxiong City, Elu Park, N2501'37.55" E101'32'12.12", on branches of Platycladus orientalis, 20 Mar. 2015, B. Cao, Q. Yang \& Z. Du (CF-2015515, living culture CFCC 50506).

Notes - Cytospora platycladi is associated with canker disease of Platycladus orientalis in China. Cytospora platycladican be distinguished from $C$. platycladicola by the independent walls of its locules. Phylogenetically, Cytospora platycladi formed a close group with $C$. lumnitzericola, but differs in its disease symptoms, with erumpent pycnidia surrounding the cracked, buff coloured bark, and the size of its conidia (4.5-5 vs 5.5-6 $\mu \mathrm{m})$ (Norphanphoun et al. 2018).

\section{Cytospora platycladicola X.L. Fan, sp. nov. - MycoBank} MB830156; Fig. 31

Etymology. The name reflects the host genus from which it was collected, Platycladus.

Ascostromata immersed in the bark, erumpent through the bark surface, (900-)1000-1600(-1750) $\mu \mathrm{m}$ diam, with 8-12 perithecia arranged irregularly. Conceptacle absent. Ectostromatic disc light grey to black, nearly flat, circular to ovoid, (300-)330-420(-440) $\mu \mathrm{m}$ diam, with 6-10 ostioles arranged circularly per disc. Ostioles dark brown to black, occasionally the area below the disc with a paler entostroma, concentrated, arranged circularly in a disc, (44-)50-75(-82) $\mu \mathrm{m}$ diam. Perithecia dark brown, flask-shaped to spherical, arranged circularly, (220-)240-330(-370) $\mu \mathrm{m}$ diam. Asci free, clavate to elongate-obovoid, $(45-) 48-60(-67) \times(8-) 8.5-10(-11)$ $\mu \mathrm{m}, 8$-spored. Ascospores biseriate, elongate-allantoid, thinwalled, hyaline, aseptate, $12-12.5(-13) \times 3-4 \mu \mathrm{m}$. Pycnidial stromata ostiolate, immersed in bark, scattered, erumpent through the bark surface, discoid, with favaginous, multiple locules. Conceptacle absent. Ectostromatic disc white to light brown, circular to ovoid, (250-)260-320(-350) $\mu \mathrm{m}$ diam, with single ostiole per disc. Ostiole in the centre of the disc, conspicuous, dark grey to black, (80-)90-110(-120) $\mu \mathrm{m}$ diam.
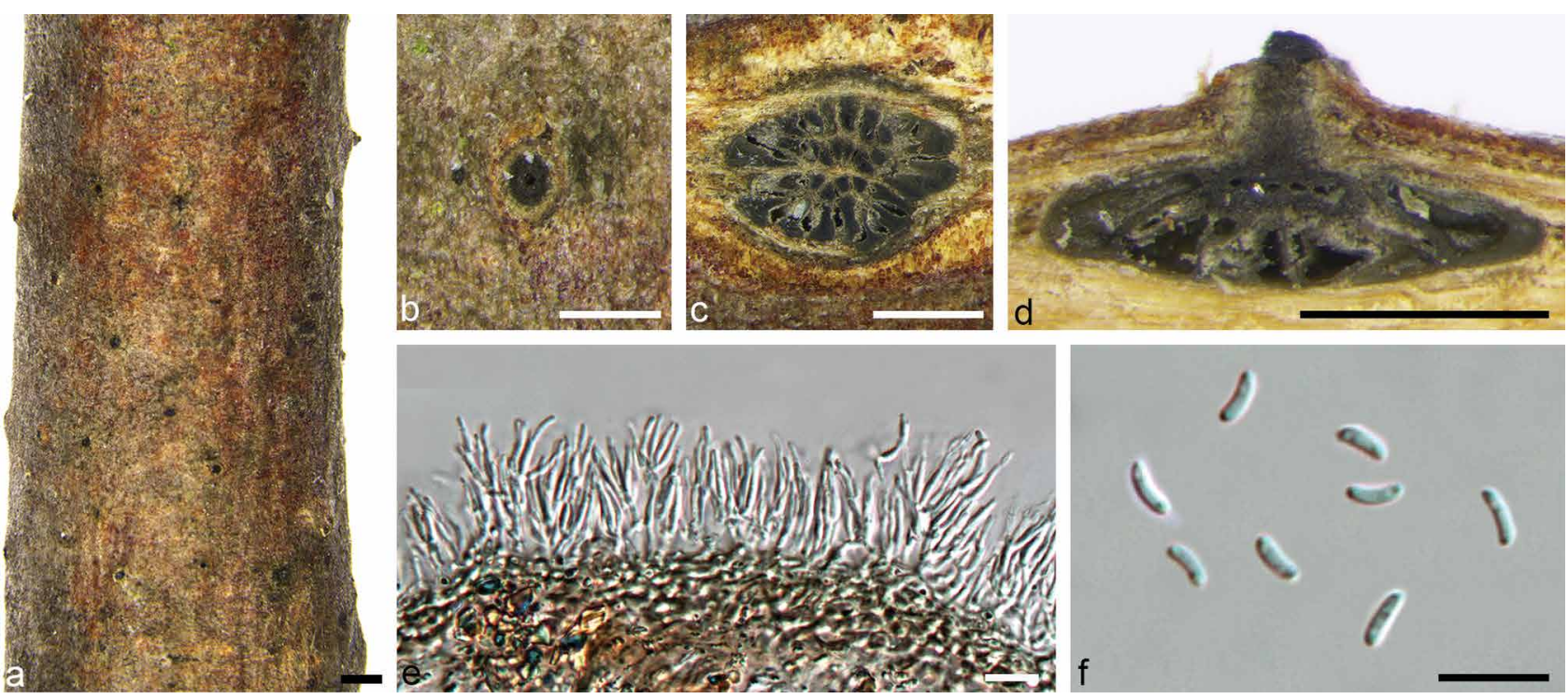

Fig. 30 Cytospora platycladi on Platycladus orientalis (BJFC-S1111). a-b. Habit of conidiomata on branch; c. transverse section through conidioma; d. longitudinal section through conidioma; $e$. conidiogenous cells with attached conidia; $f$. conidia. - Scale bars: $a=1 \mathrm{~mm} ; b-d=0.5 \mathrm{~mm} ; \mathrm{e}-\mathrm{f}=10 \mu \mathrm{m}$. 

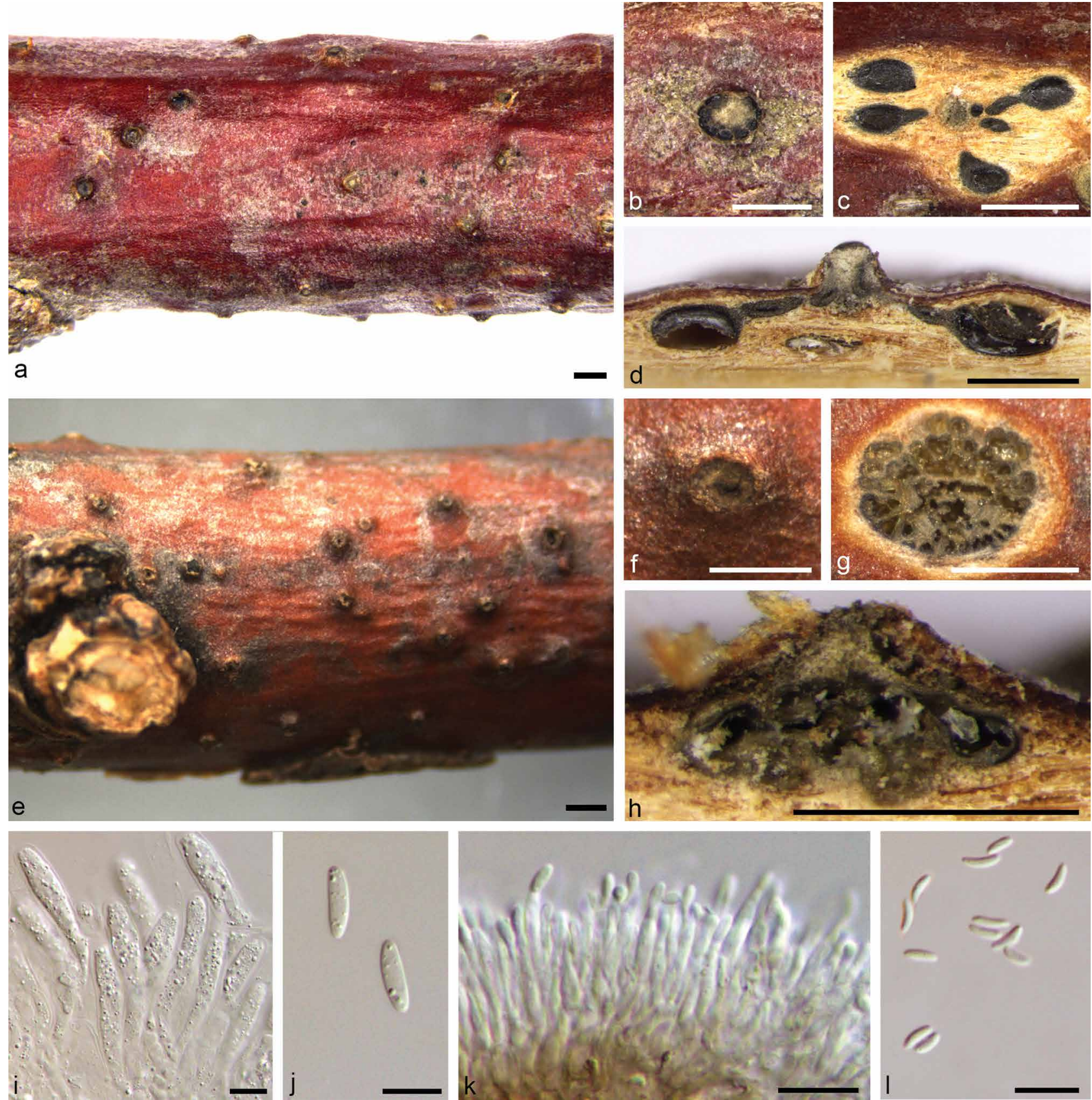

Fig. 31 Cytospora platycladicola on Platycladus orientalis (BJFC-S758). a-b. Habit of ascostromata on branch; c. transverse section through ascostroma; d. longitudinal section through ascostroma; $\mathrm{e}-\mathrm{f}$. habit of conidiomata on branch; $\mathrm{g}$. transverse section through conidioma; $\mathrm{h}$. longitudinal section through conidioma; i. asci; j. ascospores; k. conidiogenous cells with attached conidia; I. conidia. - Scale bars: $a, e=1 \mathrm{~mm} ; \mathrm{b}-\mathrm{d}, \mathrm{f}-\mathrm{h}=0.5 \mathrm{~mm} ; \mathrm{i}-\mathrm{I}=10 \mu \mathrm{m}$.

Locules numerous, arranged irregularly with common walls, (500-)520-700(-750) $\mu \mathrm{m}$ diam. Conidiophores borne along the locules, hyaline, branched at the base or unbranched, thinwalled, 11-20 × 1.5-2 $\mu \mathrm{m}$, embedded in a gelatinous layer. Conidiogenous cells enteroblastic, phialidic, sub-cylindrical to cylindrical, $8-15 \times 1.5-2 \mu \mathrm{m}$, tapering towards the apices. Conidia hyaline, allantoid, eguttulate, smooth, aseptate, thinwalled, $(4-) 4.5-5(-5.5) \times 1.5-2 \mu \mathrm{m}$.

Culture characteristics - On PDA, colonies white to greyish, fluffy, growing up to $5 \mathrm{~cm}$ diam after $3 \mathrm{~d}$, entirely covering the $9 \mathrm{~cm}$ Petri dish after $7 \mathrm{~d}$, becoming yellowish to pale yellow after $30 \mathrm{~d}$. Pycnidia extruding a pale white to yellowish conidial mass, sparse and distributed irregularly on the medium surface.

Materials examined. CHINA, Gansu Province, Longnan City, Wen County, Tianchi Lake, N33 ${ }^{\circ} 14^{\prime} 33.21^{\prime \prime}$ E104 ${ }^{\circ} 44^{\prime} 18.91^{\prime \prime}$, on twigs and branches of Platycladus orientalis, 11 Aug. 2012, X.L. Fan (holotype BJFC-S758, ex-type living culture CFCC 50038); ibid., BJFC-S755, living culture CFCC 50039.
Notes - Cytospora platycladicola is associated with canker disease of Platycladus orientalis in China. In the combined analyses, the most closely related species are $C$. ampulliformis and C. cotini (Fig. 4). Cytospora platycladicola can be distinguished from $C$. ampulliformis and $C$. cotini by pycnidia having a central column with a single ostiole in the disc, as well as the smaller conidia (4.5-5 × 1.5-2 $\mu \mathrm{m})$ (Hyde et al. 2016, Norphanphoun et al. 2017).

Cytospora populina (Pers.) Rabenh., Deutschl. Krypt.-FI. (Leipzig) 1: 148. 1844 - Fig. 32

Basionym. Sphaeria populina Pers., Observ. Mycol. (Lipsiae) 2: 67. 1800. Synonyms. Valsa populina (Pers.) Fuckel, Jahrb. Nassauischen Vereins Naturk. 25: 314. 1871.

Cryptosporella populina (Pers.) Sacc., Michelia 1: 30. 1877.

Diaporthe populina (Pers.) Höhn., Ann. Mycol. 16: 106. 1918.

Cryptodiaporthe populina (Pers.) Petr., Ann. Mycol. 19: 119. 1921

Cytospora populina (Fuckel) C.M. Tian et al., Phytotaxa 197: 234. 2015. 

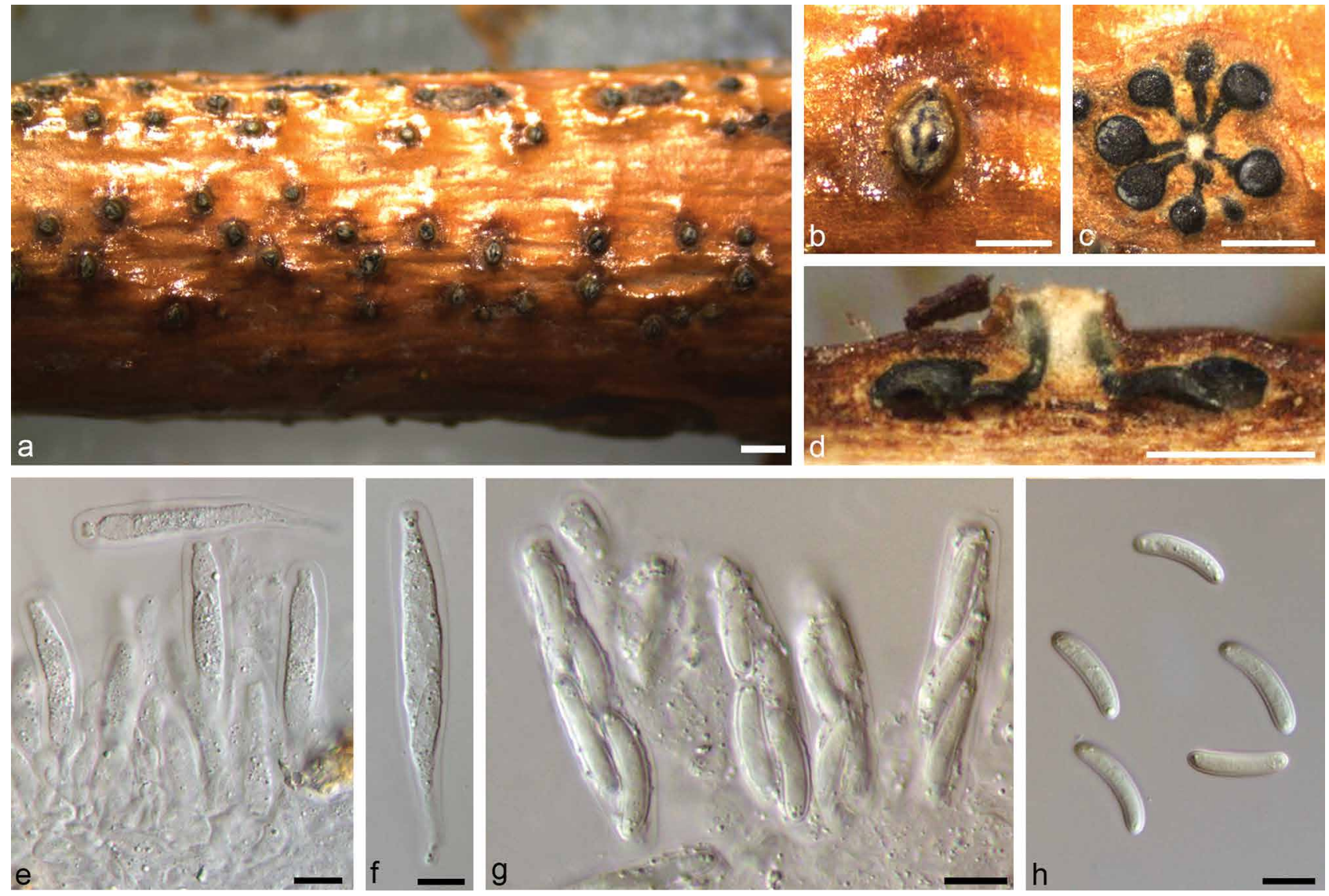

Fig. 32 Cytospora populina on Salix psammophila (BJFC-S978). a-b. Habit of ascostromata on branch; c. transverse section through ascostroma; d. longitudinal section through ascostroma; $\mathrm{e}-\mathrm{g}$. asci (e, fimmature); $\mathrm{h}$. ascospores. - Scale bars: $\mathrm{a}=1 \mathrm{~mm} ; \mathrm{b}-\mathrm{d}=0.5 \mathrm{~mm} ; \mathrm{e}-\mathrm{h}=10 \mu \mathrm{m}$.

Description - See Fan et al. (2015b).

Material examined. CHINA, Shaanxi Province, Yulin City, Hongshi Gorge, N38 $19^{\prime} 40.83^{\prime \prime} \mathrm{E} 109^{\circ} 42^{\prime} 37.98^{\prime \prime}$, from twigs and branches of Salix psammophila, 29 July 2013, X.L. Fan (BJFC-S978, living culture CFCC 89644).

Notes - Cytospora populina (syn. Valsa populina) is regarded as the pathogen responsible for poplar canker. Fan et al. (2015b) re-described this species from materials in China and observed that it has asci with four ascospores, which was also observed in the present study.

Cytospora populinopsis X.L. Fan \& C.M. Tian, sp. nov. MycoBank MB830157; Fig. 33

Etymology. Named after its morphological similarity to C. populina.

Ascostromata immersed in the bark, erumpent through the bark surface, (1180-)1320-1750(-1910) $\mu \mathrm{m}$ diam, with 6-12 perithecia arranged irregularly. Conceptacle absent. Ectostromatic disc pale grey to black, nearly flat, circular to ovoid, (240-) $280-470(-530) \mu \mathrm{m}$ diam, with $6-12$ ostioles arranged circularly per disc. Ostioles dark brown to black, the area below disc occasionally with a lighter entostroma, arranged circularly and tightly in a disc, (54-)61.5-96(-115) $\mu \mathrm{m}$ diam. Perithecia dark brown, flask-shaped to spherical, arranged circularly, (260-) $310-460(-500) \mu \mathrm{m}$ diam. Asci free, clavate to elongate obovoid, (42.5-)45-53.5(-58) × (7-)8-10(-11) $\mu \mathrm{m}, 4$-spored. Ascospores hyaline, biseriate, elongate-allantoid, aseptate, guttulate, thin-walled, (13-)14-20(-21) × (2.5-)3-4.5(-5) $\mu \mathrm{m}$. Asexual morph not observed.

Culture characteristics - On PDA, colonies white to pale mouse grey, fluffy, growing up to $6 \mathrm{~cm}$ diam after $3 \mathrm{~d}$ and entirely covering the $9 \mathrm{~cm}$ Petri dish after $7 \mathrm{~d}$. Pycnidia black, distributed circularly at the colony margin on the medium surface.
Materials examined. CHINA, Ningxia Province, Guyuan City, Jingyuan County, Liupan Mountain, N35²3'57.91" E106 ${ }^{\circ} 23^{\prime} 11.94 "$ ", on twigs and branches of Sorbus aucuparia, 23 July 2013, X.L. Fan (holotype BJFCS802, ex-type living culture CFCC 50032); Guyuan City, Jingyuan County, Nanzhuang Town, N35 $23^{\prime} 29.84^{\prime \prime}$ E $106^{\circ} 23^{\prime} 29.84^{\prime \prime}$, on twigs and branches of Prunus salicina, 22 July 2013, X.L. Fan (BJFC-S818, living culture CFCC 50033).

Notes - Cytospora populinopsis is associated with canker disease of Prunus salicina and Sorbus aucuparia in China. It differs from other similar Cytospora species in having 4-spored asci, except from $C$. populina, which also has the same characteristic. Cytospora populinopsis can be distinguished from C. populina by its larger ascospores $(13-21 \times 2.5-5 \mu \mathrm{m}$ vs $12-13 \times 3-4 \mu \mathrm{m}$ in C. populina).

Cytospora pruinopsis C.M. Tian \& X.L. Fan, Mycol. Progr. 14: 74. 2015 - Fig. 34

Description — See Yang et al. (2015).

Materials examined. CHINA, Shaanxi Province, Yulin City, Yuyang District, Red Stone Gorge, N38 $19^{\prime} 32.43^{\prime \prime}$ E109 $42^{\prime} 00.63^{\prime \prime}$, on twigs and branches of Ulmus pumila, 29 July 2013, X.L. Fan (holotype BJFC-S1073, ex-type living culture CFCC 50034); Jilin Province, Tonghua City, N41 ${ }^{\circ} 73^{\prime} 56.12^{\prime \prime}$ E125 $96^{\prime} 85.84^{\prime \prime}$, on twigs and branches of Ulmus pumila, 3 June 2012, Y.B. Zhang (BJFC-S334, living culture CFCC 50035).

Notes - Cytospora pruinopsis was described to be associated with a canker disease of Ulmus pumila in China (Yang et al. 2015). This Cytospora species is characterised by a single locule, distinguishing it from C. carbonacea, C. chrysosperma, C. leucosperma, C. leucostoma, C. pulchella and C. sacculus, which are common species from Ulmus spp. with multiple locules (Yang et al. 2015). Cytospora pruinopsis is similar to C. pruinosa, but differs in the absence of a wing-like ectostroma 


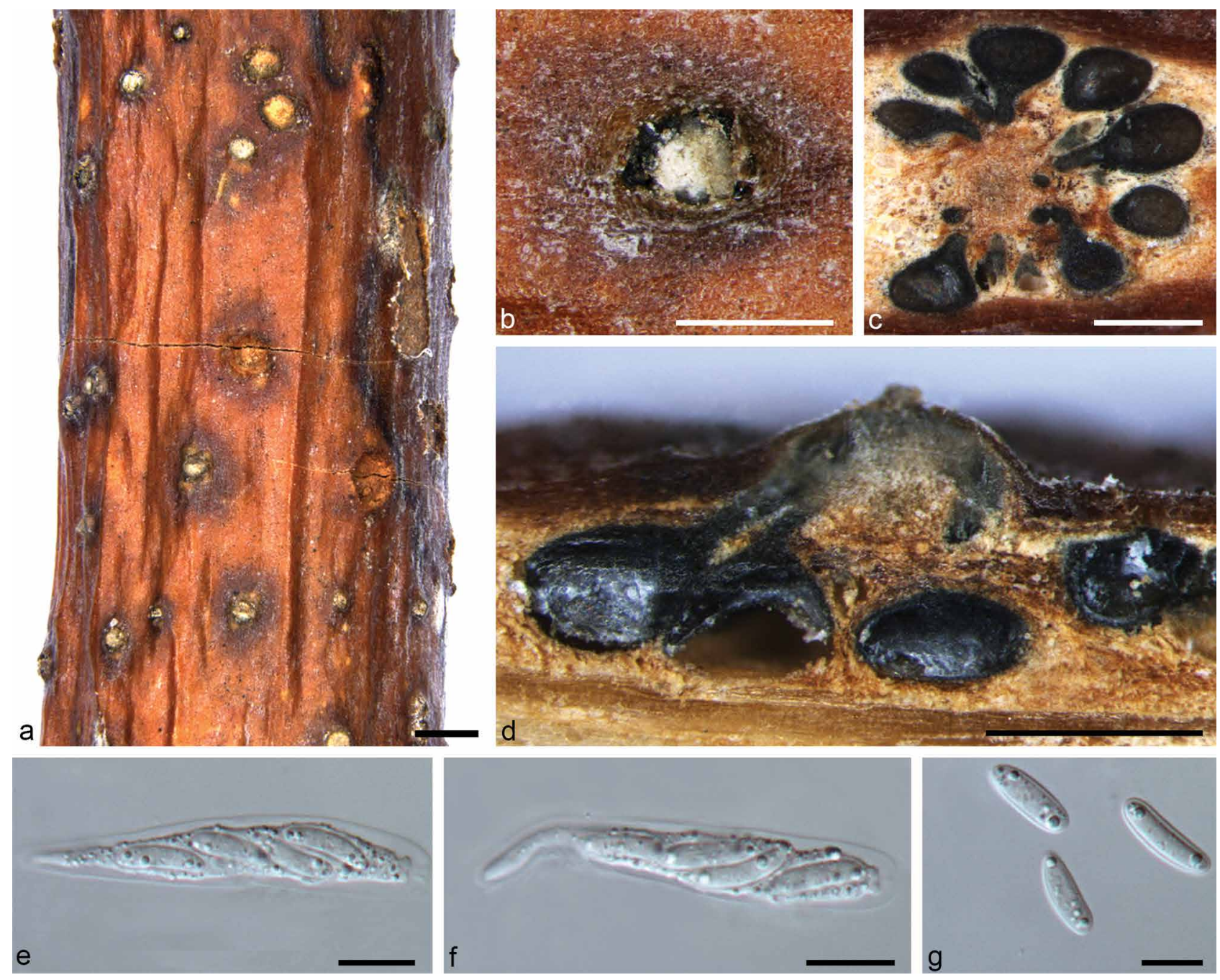

Fig. 33 Cytospora populinopsis on Sorbus aucuparia (BJFC-S802). a-b. Habit of ascostromata on branch; c. transverse section through ascostroma; d. longitudinal section through ascostroma; $e-f$. asci; $g$. ascospores. - Scale bars: $a=1 \mathrm{~mm} ; b-d=0.5 \mathrm{~mm} ; \mathrm{e}-\mathrm{g}=10 \mu \mathrm{m}$

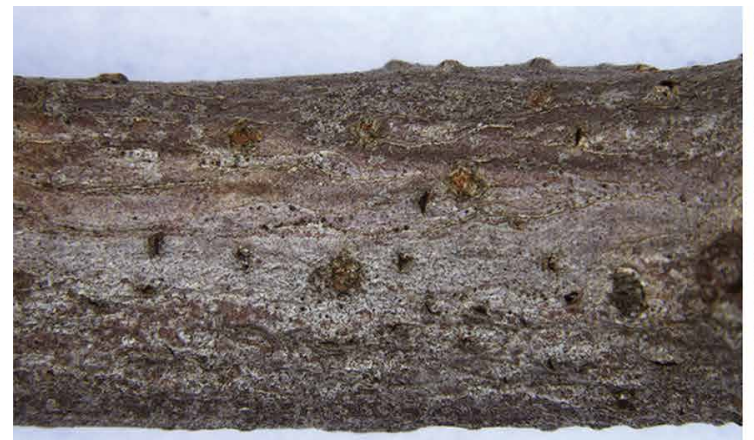

a
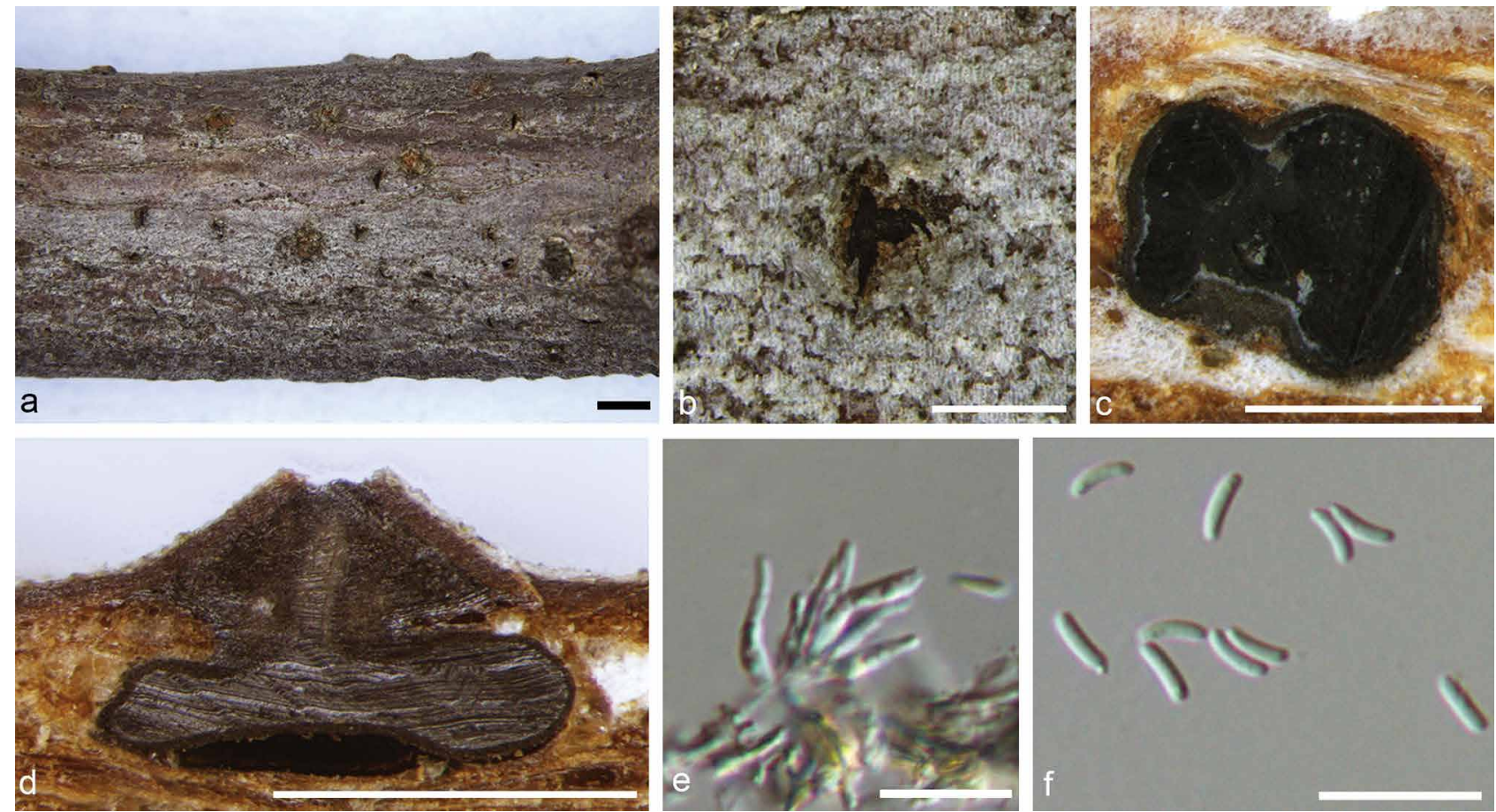

Fig. 34 Cytospora pruinopsis on UImus pumila (BJFC-S1073). a-b. Habit of conidiomata on branch; c. transverse section through conidioma; d. longitudinal section through conidioma; e. conidiogenous cells with attached conidia; f. conidia. - Scale bars: $a=2 \mathrm{~mm} ; b-d=0.5 \mathrm{~mm} ; e-f=10 \mu \mathrm{m}$. 

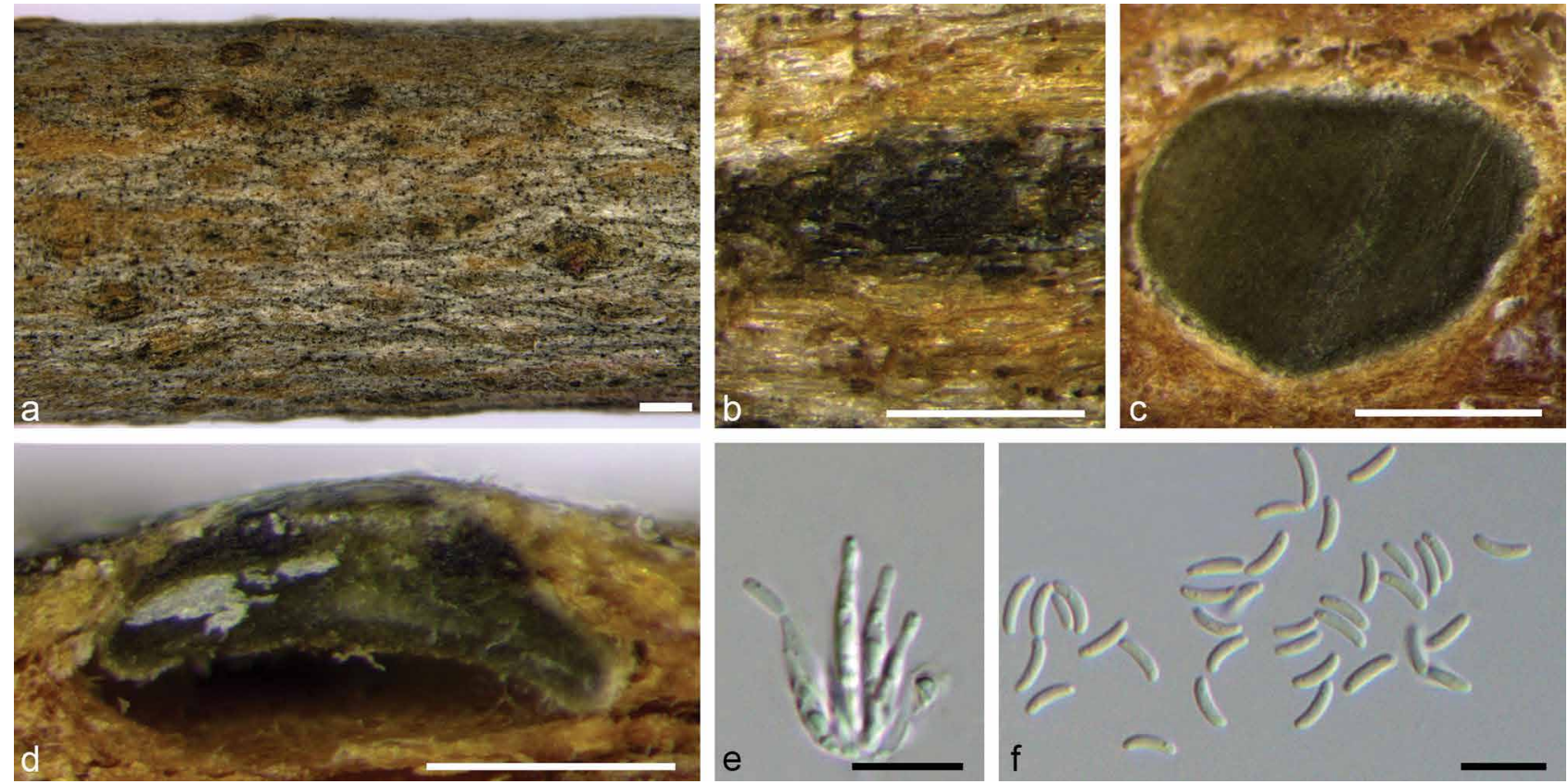

Fig. 35 Cytospora pruinosa on Syringa oblata (BJFC-S636). a-b. Habit of conidiomata on branch; c. transverse section through conidioma; d. longitudinal section through conidioma; e. conidiogenous cells with attached conidia; f. conidia. - Scale bars: $a=1 \mathrm{~mm} ; b-d=0.25 \mathrm{~mm} ; e-f=10 \mu \mathrm{m}$.

around the ostiole, smaller conidial size $(3.0 \times 0.8 \mu \mathrm{m}$ vs $5-7.5$ $\times 1-1.5$ in C. pruinosa), and host affiliations (Yang et al. 2015).

\section{Cytospora pruinosa (Fr.) Sacc., Michelia 1(5): 519. 1879} Fig. 35

Basionym. Sphaeria pruinosa Fr., Kongl. Svenska Vetensk.-Akad. Handl. (Ser. 3) 39: 104. 1818.

Synonym. Sphaeria cypri Tul., Compt. Rend. Hebd. Séances Acad. Sci., Paris 42: 706. 1856.

Valsa cypri (Tul.) Tul. \& C. Tul., Select. Fung. Carpol. (Paris) 2: 194. 1863.

Sexual morph not observed. Pycnidial stromata immersed in bark, erumpent through the bark surface, discoid, with a solitary undivided locule. Conceptacle absent. Ectostromatic disc dark grey to black, inconspicuous, with one ostiole per disc. Ostiole dark grey to black, conspicuous, (61-)65-74(-78) $\mu \mathrm{m}$ diam. Locules undivided, circular to ovoid, with wing-like ectostroma around the ostiole, (400-)430-550(-590) $\mu \mathrm{m}$ diam. Conidiophores borne along the locules, hyaline, unbranched or occasionally branched at base, 10-19(-20.5) $\times 2-2.5 \mu \mathrm{m}$, embedded in a gelatinous layer. Conidiogenous cells enteroblastic, phialidic, sub-cylindrical to cylindrical, $10-17 \times 2-2.5 \mu \mathrm{m}$, tapering towards apices. Conidia hyaline, allantoid, occasionally guttulate, smooth, aseptate, thin-walled, (5-)5.5-7(-7.5) $\times(1-) 1.5 \mu \mathrm{m}$.

Culture characteristics - On PDA, colonies white to slightly pale mouse grey at the centre, fluffy, growing up to $6 \mathrm{~cm}$ diam after $3 \mathrm{~d}$, becoming flat, lacking aerial mycelium after $30 \mathrm{~d}$, secreting a cinnamon pigment in the medium. Pycnidia are black, distributed irregularly on the medium surface.

Materials examined. CHINA, Qinghai Province, Haidong City, Pinan County,

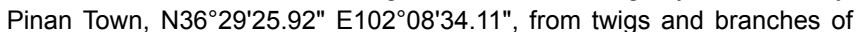
Syringa oblata, 15 Aug. 2012, X.L. Fan (BJFC-S636, living culture CFCC 50036); ibid., BJFC-S640, living culture CFCC 50037.

Notes - Cytospora pruinosa is a common species observed worldwide on Fraxinus, Olea, Syringa and Viburnum lantana (Saccardo 1879, Adams et al. 2006). Adams et al. (2006) redescribed this species from Olea europaea in South Africa and provided ITS sequences.
Cytospora ribis Ehrenb., Sylv. Mycol. Berol. (Berlin): 28. 1818

Description - See Yang et al. (2015).

Materials examined. CHINA, Qinghai Province, Xining City, N36 $38^{\prime} 32.51^{\prime \prime}$ E1014' $42.89^{\prime \prime}$, from stems of Ulmus pumila, 19 Aug. 2012, X.L. Fan (BJFC S671, living culture CFCC 50026); ibid., living culture CFCC 50027.

Notes - Cytospora ribis has been reported from China, Iran, the Netherlands and Poland (Mulenko et al. 2008, Fotouhifar et al. 2010, Yang et al. 2015). Yang et al. (2015) described it from Ulmus having typical Cytospora pycnidia with 1-4 ostioles and small elongate-allantoid conidia $(3.5-4.5 \times 1-1.5 \mu \mathrm{m})$ from Ulmus pumila in China.

\section{Cytospora rostrata C.M. Tian \& X.L. Fan, Mycotaxon 129: 307. 2014}

Description - See Fan et al. (2014b).

Materials examined. CHINA, Gansu Province, Ganan City, Diebu County, N34 $04^{\circ} 48.85^{\prime \prime} \mathrm{E} 103^{\circ} 23^{\prime} 34.20 "$, from stems of Salix cupularis, 9 Aug. 2012, Y.M. Liang \& X.L. Fan (holotype BJFC S726, ex-type living culture CFCC 89909 = BJFC-CGLs251); Gansu Province, Ganan City, Diebu County, N34 $04^{\circ} 48.35^{\prime \prime} \mathrm{E} 103^{\circ} 23^{\prime} 36.60^{\prime \prime}$, from stems of Salix cupularis, 9 Aug. 2012, Y.M. Liang \& X.L. Fan (BJFC S727, living culture CFCC $89910=$ BJFCCGLs252).

Notes - Cytospora rostrata has small, single loculed pycnidia (455-851 $\mu \mathrm{m}$ diam), with thorn-like necks erumpent through the host bark, which differs from C. chrysosperma by its multiple locules (640-1260 $\mu \mathrm{m}$ diam) with nearly flat, circular to ovoid disc (Fan et al. 2014b). Cytospora rostrata was only recorded from stems of Salix cupularis in China (Fan et al. 2014b).

\section{Cytospora schulzeri Sacc. \& P. Syd., Syll. Fung. (Abellini)}

14(2): 918.1899 - Fig. 36

Synonyms. Cytospora capitata Schulzer \& Sacc., Hedwigia 23: 109. 1884, non Cytospora capitata Fuckel, Reisen nach dem Nordpolarmeer 2: 34 (1874).

Valsa malicola Z. Urb., Česká Mykol. 10: 209. 1956.

Ascostromata immersed in the bark, erumpent through the bark surface, scattered, (980-)1060-1430(-1600) $\mu \mathrm{m}$ diam, with $5-14$ perithecia arranged circularly or irregularly. Conceptacle 

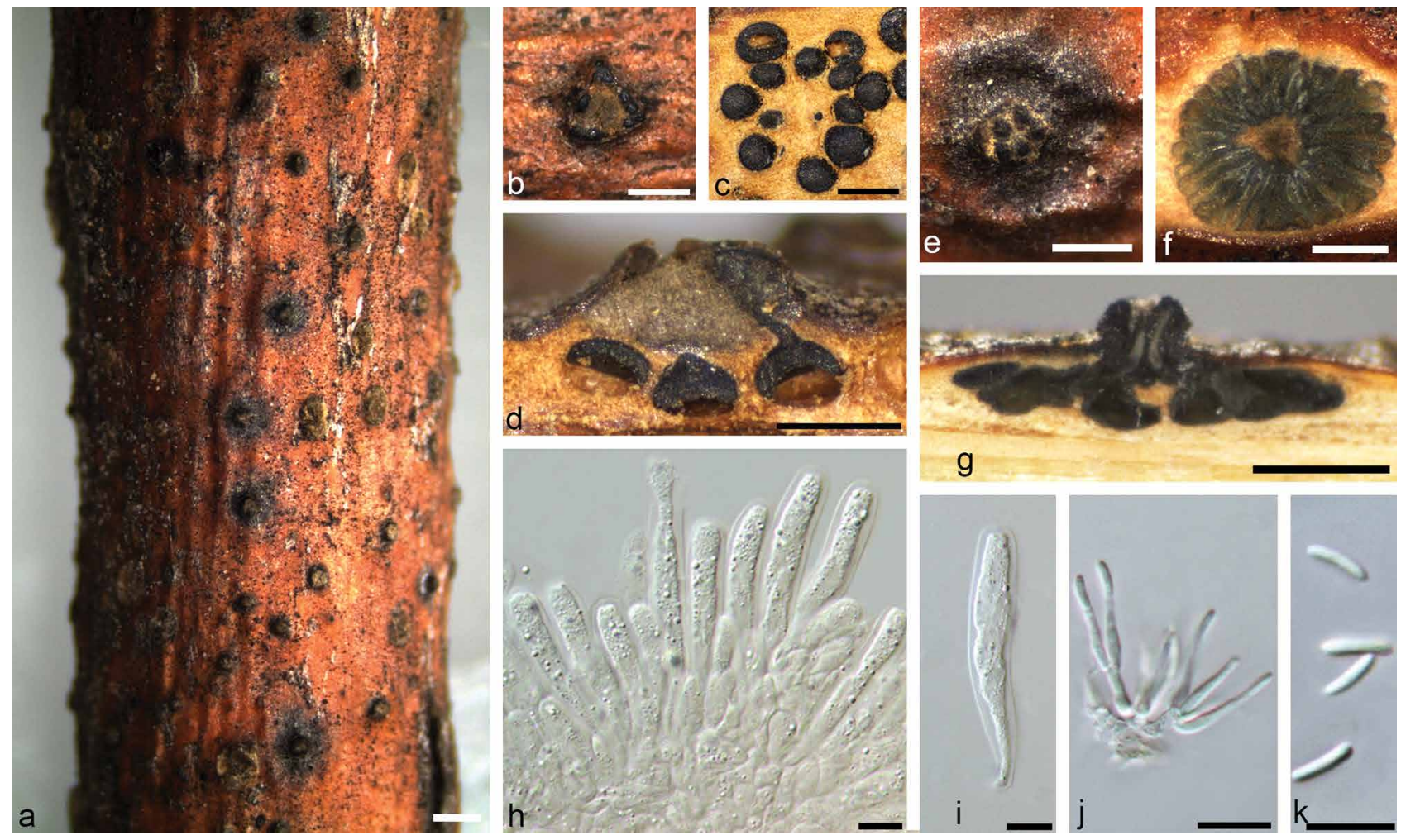

Fig. 36 Cytospora schulzeri on Malus pumila (BJFC-S538). a. Habit of conidiomata and ascostromata on branch; b. habit of ascostroma on branch; c. transverse section through ascostroma conidioma; $d$. longitudinal section through ascostroma; e. habit of conidioma on branch; f. transverse section through conidioma; $\mathrm{g}$. longitudinal section through conidioma; $\mathrm{h}-\mathrm{i}$. asci; $\mathrm{j}$. conidiogenous cells with attached conidia; $\mathrm{k}$. conidia. $-\mathrm{Scale}$ bars: $\mathrm{a}=1 \mathrm{~mm} ; \mathrm{b}-\mathrm{g}=0.5 \mathrm{~mm}$; $\mathrm{h}-\mathrm{k}=10 \mu \mathrm{m}$

absent. Ectostromatic disc grey to black, usually surrounded by tightly ostiolar necks, circular to ovoid, (285-)310-450(-465) $\mu \mathrm{m}$ diam, with 5-14 ostioles arranged circularly per disc. Ostioles black, concentrated, dark brown to black, arranged circularly in a disc, (56-)63-103(-122) $\mu \mathrm{m}$ diam. Perithecia dark brown, flask-shaped to spherical, arranged circularly or irregularly, (235-)250-310(-350) $\mu \mathrm{m}$ diam. Asci free, clavate to elongate obovoid, (22.5-)37-45.5(-49) × (4-)5.5-9(-10) $\mu \mathrm{m}$. Ascospores not observed. Pycnidial stromata ostiolate, immersed in bark, scattered, erumpent through the bark surface, flat, discoid, with multiple locules. Conceptacle absent. Ectostromatic disc light brown, circular, (145-)160-390(-420) $\mu \mathrm{m}$ diam, with 1-7 ostioles per disc. Ostiole numerous, conspicuous, dark grey to black, arranged circularly, (25-)29-50(-71) $\mu \mathrm{m}$ diam. Locules numerous, arranged circularly with common walls, (830-)870-1320(-1410) $\mu \mathrm{m}$ diam. Conidiophores borne along the locules, hyaline, branched at base or unbranched, thin-walled, $12-19 \times 1.5-2 \mu \mathrm{m}$, embedded in a gelatinous layer. Conidiogenous cells enteroblastic, phialidic, sub-cylindrical to cylindrical, $6.5-12(-13.5) \times 2 \mu \mathrm{m}$, tapering towards apices. Conidia hyaline, allantoid, eguttulate, smooth, aseptate, thinwalled, (4.0-)4.5-6.5(-7) × 1-1.5 $\mu \mathrm{m}$.

Culture characteristics - On PDA, colonies fast growing, reaching up to $8 \mathrm{~cm}$ diam after $3 \mathrm{~d}$ and entirely covering the $9 \mathrm{~cm}$ Petri dish after $4 \mathrm{~d}$, centrally white and olivaceous grey at the margin, becoming olivaceous black at the centre and iron-grey on the margin after $30 \mathrm{~d}$. Colonies are slightly fluffy, thin with a uniform texture; sterile.

Materials examined. CHINA, Ningxia Province, Yinchuan City, N38²7'40" E106 $01^{\prime} 00^{\prime \prime}$, on branches of Malus pumila, 2 June 2012, X.L. Fan (BJFCS538, living culture CFCC 50040); Gansu Province, Gannan City, Diebu County, Zhouqu Town, N33 ${ }^{\circ} 46^{\prime} 56.55^{\prime \prime}$ E104 ${ }^{\circ} 20^{\prime} 12.65^{\prime \prime}$, from branches of Malus pumila, 10 Aug. 2012, X.L. Fan (BJFC-S773, living culture CFCC 50042).
Notes - Cytospora schulzeri is a common species causing apple canker disease (Teng 1963, Tai 1979, Wei 1979, Zhuang 2005, Wang et al. 2011). This species can be distinguished from C. mali by numerous ostioles and erumpent pycnidia.

Cytospora sibiraeae C.M. Tian et al., Fungal Diversity 72: 44. 2015 - Fig. 37

Description — See Liu et al. (2015).

Materials examined. CHINA, Gansu Province, Gannan City, N34³1'50.10" E103 $08^{\circ} 32.47^{\prime \prime}$, on branches of Sibiraea angustata, 8 Aug. 2012, X.L. Fan \& Y.M. Liang (holotype BJFC-S783, ex-type living culture CFCC 50045); ibid., living culture CFCC 50046 .

Notes - Cytospora sibiraeae has been reported in China from twigs and branches of Sibiraea angustata, and this species is mainly characterised by ascostromata with black conceptacles (Liu et al. 2015). Few pathogenic fungi were reported in S. angustata from China, and C. sibiraeae represents the first Cytospora species reported from this host plant (Liu et al. 2015).

Cytospora sophorae Bres., Fungi Trident. 2: 44. 1892 - Fig. 38

Description - See Fan et al. (2014a).

Materials examined. CHINA, Gansu Province, Lanzhou City, N3603'45.37" E103 47'61.72", on branches of Styphnolobium japonicum, 13 Aug. 2012, X.L. Fan (BJFC-S698, living culture CFCC 89598); Shanxi Province, Datong City, Children's Park, N4004'45.36" E113¹6'39.56", on branches of Styphnolobium japonicum, 14 Apr. 2014, X.L. Fan (BJFC-S1037, living culture CFCC 50047); Changzhi City, Guyi Nursery Garden, N36²1'13.36" E113'12'14.56", on branches of Magnolia grandiflora, 19 Apr. 2014, X.L. Fan (BJFC-S1069, living culture CFCC 50048).

Notes - Cytospora sophorae is a common plant pathogenic fungus causing Cytospora canker on Styphnolobium japonicum (syn. Sophora japonica). The current identification follows previ- 

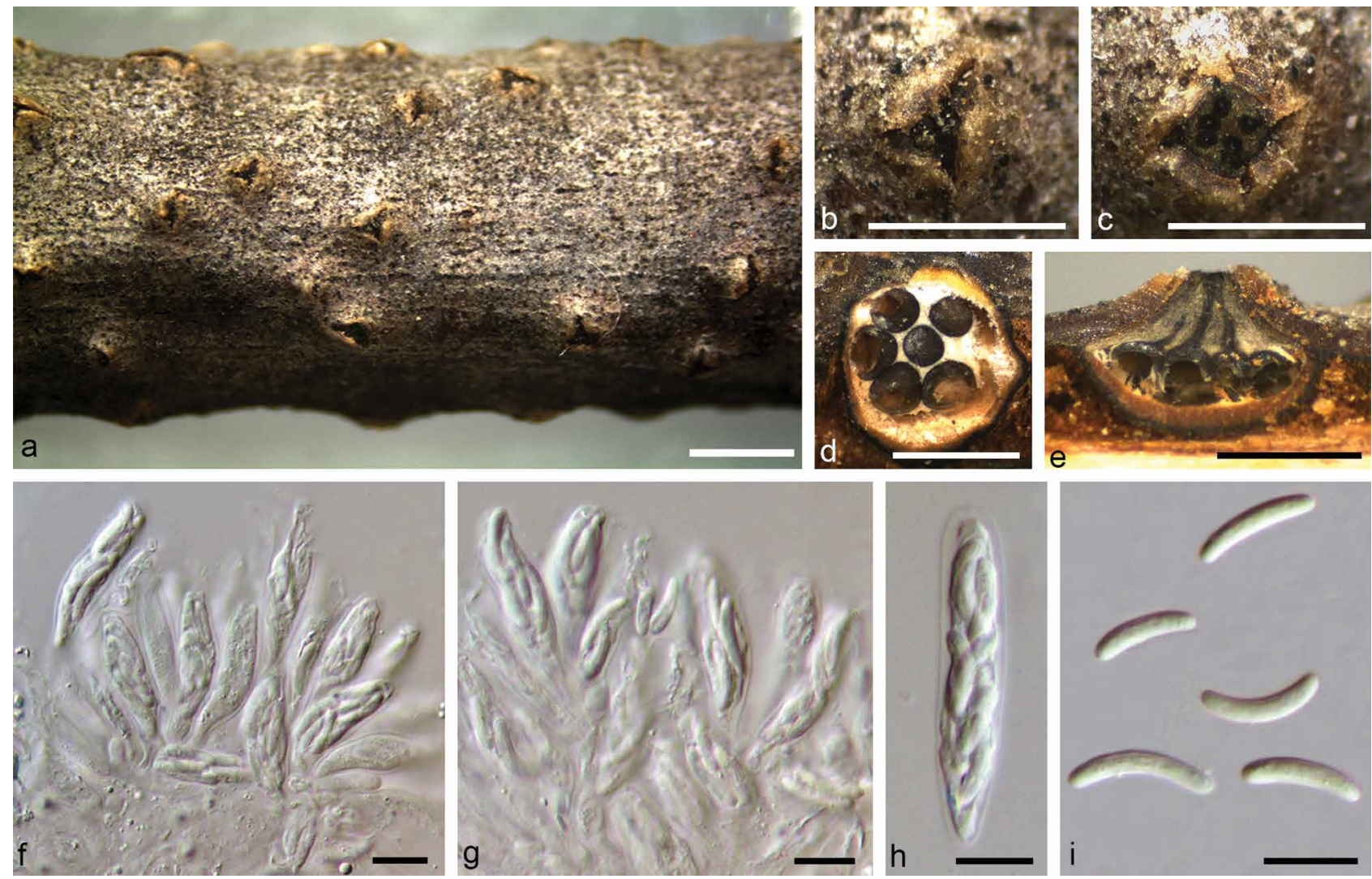

Fig. 37 Cytospora sibiraeae on Sibiraea angustata (BJFC-S783). a-b. Habit of ascostromata on branch; c. ectostromatic disc with ostioles; d. transverse section through ascostroma; e. longitudinal section through ascostroma; $f-h$. asci; i. ascospores. $-\mathrm{Scale}$ bars: $a=1 \mathrm{~mm} ; \mathrm{b}-\mathrm{e}=0.5 \mathrm{~mm} ; \mathrm{f}-\mathrm{i}=10 \mu \mathrm{m}$.

ous descriptions and records in China, whereas a typification for a stable species concept is required (Tai 1979, Teng 1996, Fan et al. 2014a). Cytospora sophorae can be identified by cultural characters (cultures grow up to $7 \mathrm{~cm}$ after $30 \mathrm{~d}$ with an irregular edge, having a dark brown pigment), which differs from C. sophoricola (beak-shaped pycnidia produced in white cultures without a dark pigment) and $C$. sophoriopsis (cultures are white in the centre and straw at the margins). This is the first report of this fungus from Magnolia grandiflora.

\section{Cytospora sophoricola C.M. Tian \& X.L. Fan, Mycoscience} 55: 254. 2014 - Fig. 39

Description - See Fan et al. (2014a).

Materials examined. CHINA, Gansu Province, Gannan City, Lintan County, N34 $57^{\circ} 56.17^{\prime \prime} \mathrm{E} 103^{\circ} 40^{\prime} 00.09^{\prime \prime}$, on branches of Styphnolobium japonicum var. pendula, 5 Aug. 2012, X.L. Fan (holotype BJFC-S694, ex-type living culture CFCC 89595); ibid., BJFC-S695, living culture CFCC 89596.

Notes - Cytospora sophoricola is similar to C. schulzeri (recorded from Malus) and to C. carbonacea (reported from Ulmus) by the presence of multiple locules with a single ostiole, but can be distinguished from those based on the diameters of the disc and locules, number of ostioles, as well as the beakshaped pycnidia produced in culture, size of the conidia, and cultural features. This species is only known from Styphnolobium japonicum var. pendula in China (Fan et al. 2014a).

Cytospora sophoriopsis X.L. Fan \& C.M. Tian, sp. nov. MycoBank MB830158; Fig. 40

Etymology. Named after its morphological similarity to C. sophorae.

Sexual morph not observed. Pycnidial stromata ostiolate, immersed in bark, scattered, erumpent through the surface, with multiple locules. Conceptacle absent. Ectostromatic disc honey to isabelline, conspicuous, circular to ovoid, (120-)150-230 $(-250) \mu \mathrm{m}$ diam, with one ostiole per disc. Ostiole in the centre of the disc, black, conspicuous, (20-)25-35(-40) $\mu \mathrm{m}$ diam. Locules numerous, subdivided frequently by invaginations with common walls, (570-)600-700(-810) $\mu \mathrm{m}$ diam. Conidiophores borne along the locules, hyaline, branched at the base, in the middle, or unbranched, thin-walled, occasionally septate, $8-15 \times$ $1-1.5 \mu \mathrm{m}$, embedded in a gelatinous layer. Conidiogenous cells enteroblastic, phialidic, sub-cylindrical to cylindrical, 5.5-9 $\times$ $1-1.5 \mu \mathrm{m}$, tapering towards the apices. Conidia hyaline, allantoid, eguttulate, smooth, aseptate, thin-walled, (3.5-)4-4.5(-5) $\times$ $1-1.5 \mu \mathrm{m}$.

Culture characteristics - On PDA, colonies white, slightly fluffy, thin with a uniform texture, fast growing, reaching up to $7.5 \mathrm{~cm}$ diam after $3 \mathrm{~d}$ entirely covering the $9 \mathrm{~cm}$ Petri dish after $5 \mathrm{~d}$, becoming thin in the centre and gradually straw at the margins after $30 \mathrm{~d}$. Pycnidia black, distributed circularly at the colony margin on medium surface.

Material examined. CHINA, Gansu Province, Ganan City, Diebu County, N34 $04^{\prime} 05.76$ "E103 ${ }^{\circ} 11^{\prime} 33.63^{\prime \prime}$, on branches of Styphnolobium japonicum, 10 Aug. 2012, X.L. Fan (holotype BJFC-S713 = BJFC-CGHs10, ex-type living culture CFCC 89600).

Notes - Cytospora sophoriopsis is associated with canker disease of Styphnolobium japonicum (syn. Sophora japonica) in China. The strain CFCC 89600 was regarded as representative of $C$. chrysosperma due to its similar morphology, and the ITS phylogram based on a restricted dataset (Fan et al. 2014a). The current study revisited this fungus and introduced $C$. sophoriopsis as a new species based on its smaller, multiple locules $(600-700$ vs $640-1260 \mu \mathrm{m})$ with honey to isabelline ectostromatic disc, and the host affiliation. The phylogenetic inferences of the combined matrix resolved C. sophoriopsis as distinct from the $C$. chrysosperma complex. 

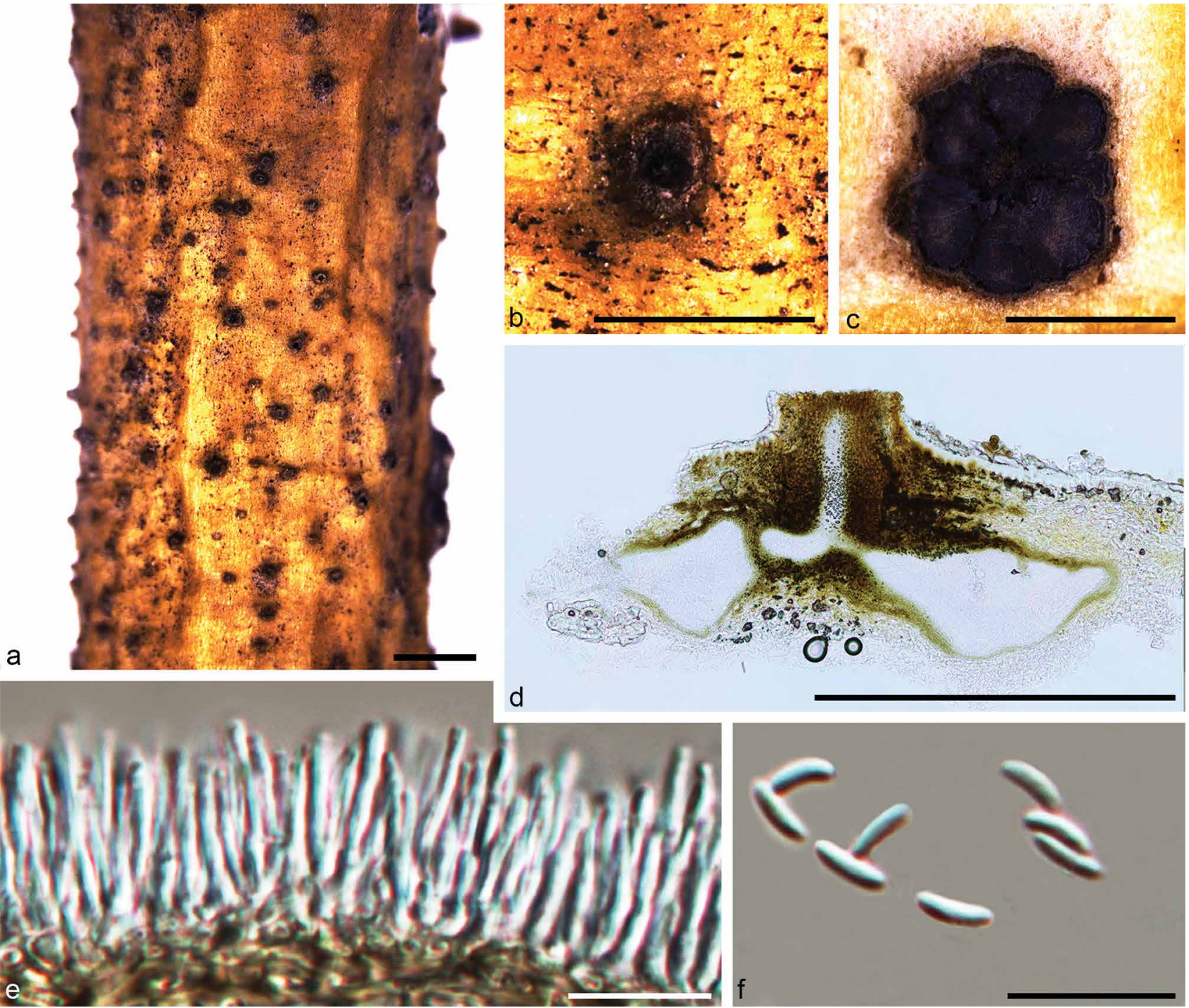

Fig. 38 Cytospora sophorae on Styphnolobium japonicum (BJFC-S698). a-b. Habit of conidiomata on branch; c. transverse section through conidioma; d. longitudinal section through conidioma; e. conidiogenous cells with attached conidia; f. conidia. - Scale bars: $a=1 \mathrm{~mm} ; b-d=0.5 \mathrm{~mm} ; e-f=10 \mu \mathrm{m}$.
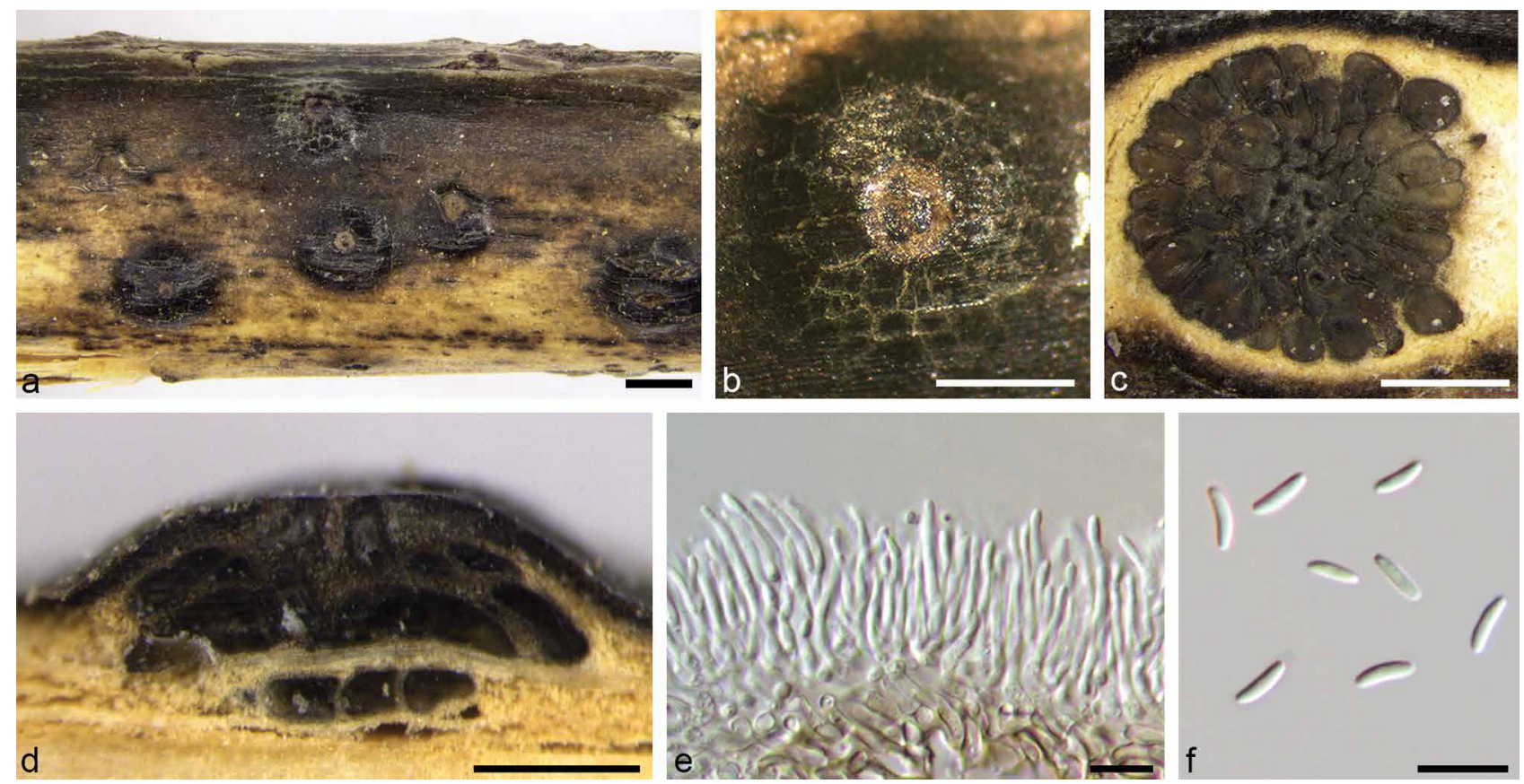

Fig. 39 Cytospora sophoricola on Styphnolobium japonicum (BJFC-S694). a-b. Habit of conidiomata on branch; c. transverse section through conidioma; d. longitudinal section through conidioma; e. conidiogenous cells with attached conidia; f. conidia. - Scale bars: $a=1 \mathrm{~mm} ; b-d=0.5 \mathrm{~mm} ; e-f=10 \mu \mathrm{m}$. 

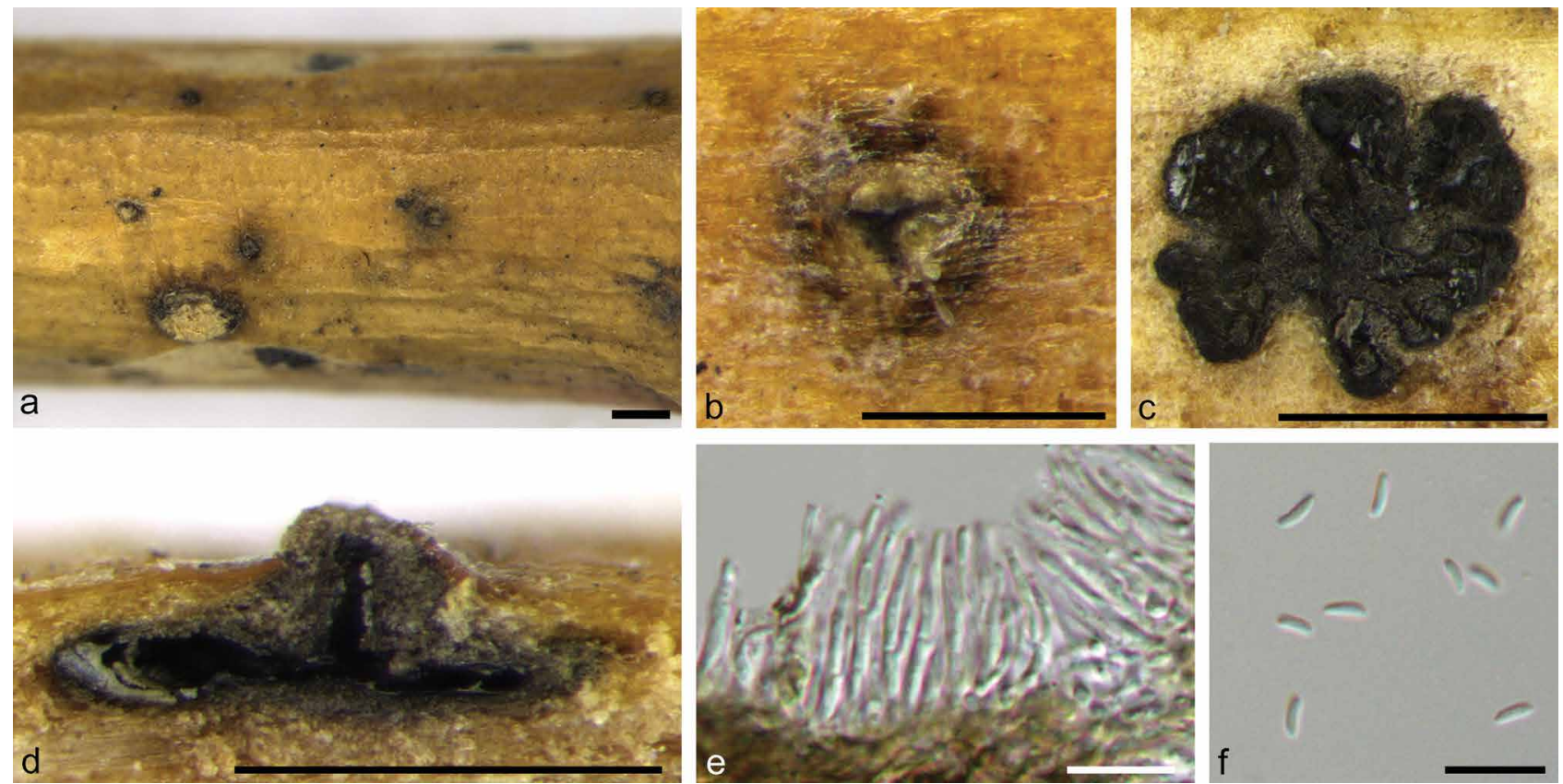

Fig. 40 Cytospora sophoriopsis on Styphnolobium japonicum (BJFC-S713). a-b. Habit of conidiomata on branch; c. transverse section through conidioma; d. longitudinal section through conidioma; e. conidiogenous cells with attached conidia; $f$. conidia. - Scale bars: $a=1 \mathrm{~mm} ; b-d=0.5 \mathrm{~mm} ; \mathrm{e}-\mathrm{f}=10 \mu \mathrm{m}$.

Cytospora spiraeae X.L. Fan, Phytotaxa 338: 57. 2018

Description - See Zhu et al. (2018).

Materials examined (all on twigs and branches of Spiraea salicifolia). CHINA, Gansu Province, Gannan City, N34¹7'22.16" E10258'44.23", 8 Aug. 2012, X.L. Fan (holotype BJFC-S784, ex-type living culture CFCC 50049); Gannan City, N34¹7'22.16" E10258'44.23", 8 Aug. 2012, X.L. Fan (BJFCS785, living culture CFCC 50050); Shanxi Province, Datong City, Wenying lake Park, N4004'32.02" E11322'13.17", 15 Apr. 2014, X.L. Fan (BJFCS1058, living culture CFCC 50051)

Notes - Cytospora spiraeae was described by Zhu et al. (2018) associated with symptomatic canker and dieback disease of Spiraea salicifolia in China. It is characterised by flaskshaped to spherical perithecia with hyaline, biseriate, aseptate, elongate-allantoid ascospores (6-8.5 × 1.5-2.5 $\mu \mathrm{m})$, and pycnidia with numerous locules as well as allantoid conidia $(5-7 \times$ 1-1.5 $\mu \mathrm{m}$ ) (Zhu et al. 2018). In the current phylogenetic trees (Fig. 3, 4), it clusters in a separate, well-supported clade.

Cytospora tamaricicola X.L. Fan \& C.M. Tian, sp. nov. - MycoBank MB830159; Fig. 41

Etymology. The name reflects the host genus from which it was collected, Tamarix.

Ascostromata immersed in the bark, erumpent through the bark surface, scattered, (1000-)1100-1400(-1550) $\mu \mathrm{m}$ diam, with 6-16 perithecia arranged circularly or irregularly. Conceptacle absent. Ectostromatic disc umber to sepia, usually surrounded by tightly aggregated ostiolar necks, (290-)310-400(-415) $\mu \mathrm{m}$ diam, with 6-16 ostioles arranged circularly per disc. Ostioles numerous, violaceous black to black, arranged irregularly and tightly in a disc, (45-)55.5-95(-115) $\mu \mathrm{m}$ diam. Perithecia dark grey to black, flask-shaped to spherical, arranged circularly or irregularly, (225-)250-380(-405) $\mu \mathrm{m}$ diam. Asci free, clavate to elongate obovoid, (31-)33.5-39(-42) × (4-)4.5-5.5(-6) $\mu \mathrm{m}, 8$-spored. Ascospores biseriate, elongate-allantoid, thinwalled, hyaline, aseptate, $(8-) 9-11.5(-12) \times 2-2.5 \mu \mathrm{m}$. Pycnidial stromata ostiolate, immersed in bark, scattered, erumpent through the surface, with multiple locules. Conceptacle absent. Ectostromatic disc greyish sepia to smoke grey, conspicuous, circular to ovoid, (175-)200-280(-305) $\mu \mathrm{m}$ diam, with one ostiole per disc. Ostiole in the centre of the disc, violaceous black to black, conspicuous, (50-)55-85(-100) $\mu \mathrm{m}$ diam. Locules numerous, subdivided frequently by invaginations with independent walls, (950-)1080-1350(-1470) $\mu \mathrm{m}$ diam. Conidiophores borne along the locules, hyaline, branched at the base, in the middle, or unbranched, thin-walled, 10-19(-22) $\times$ $1-1.5 \mu \mathrm{m}$, embedded in a gelatinous layer. Conidiogenous cells enteroblastic, phialidic, sub-cylindrical to cylindrical, $8-14.5 \times$ 1-1.5 $\mu \mathrm{m}$, tapering towards the apices. Conidia hyaline, allantoid, occasionally guttulate, smooth, aseptate, thin-walled, (5-) 5.5-6(-6.5) × 1-1.5 $\mu \mathrm{m}$.

Culture characteristics - On PDA, colonies initially white and growing up to $5 \mathrm{~cm}$ diam after $3 \mathrm{~d}$, becoming slightly buff at the margin with aerial mycelium, felt-like to slightly floccose, entirely covering the $9 \mathrm{~cm}$ Petri dish after $10 \mathrm{~d}$, thick with a uniform texture after $30 \mathrm{~d}$; sterile.

Materials examined. CHINA, Yunan Province, Kunming City, Kunming World Expo, N25ㅇ' $44^{\prime} 48.15^{\prime \prime} \mathrm{E} 102^{\circ} 45^{\prime} 30.60^{\prime \prime}$, on branches of Tamarix chinensis, 18 Mar. 2015, B. Cao, Q. Yang \& Z. Du (holotype CF-2015510, ex-type living culture CFCC 50508); Dali City, Binchuan County, Jizu Mountain, N2557'37.04" E100²3'05.77", on branches of Rosa multiflora, 23 Mar. 2015, B. Cao, Q. Yang \& Z. Du (CF-2015512, living culture CFCC 50507).

Notes - Cytospora tamaricicola is associated with canker disease of Rosa multiflora and Tamarix chinensis in China. Cytospora tamaricella was recorded from Tamarix, but without any available materials and DNA data. Cytospora tamaricicola differs from $C$. tamaricella by having smaller conidia (5.5-6 $\times$ $1-1.5$ vs $7-9 \times 1-1.5 \mu \mathrm{m}$ in C. tamaricella) (Sydow \& Sydow 1904). Morphologically, this species has pycnidial locules with independent walls, which is similar to $C$. ceratosperma which has torsellioid chambers, but can be distinguished based on its phylogenetic position (Fig. 3, 4), and the unique host Tamarix chinensis.

\section{OTHER SPECIES REPORTED FROM CHINA}

Cytospora davidiana Y.L. Wang \& X.Y. Zhang, Fungal Biol. 119: 427.2015

Notes - Cytospora davidiana was described and illustrated from stems of Populus davidiana in Inner Mongolia and Heilongjiang Provinces, China (Wang et al. 2015). 

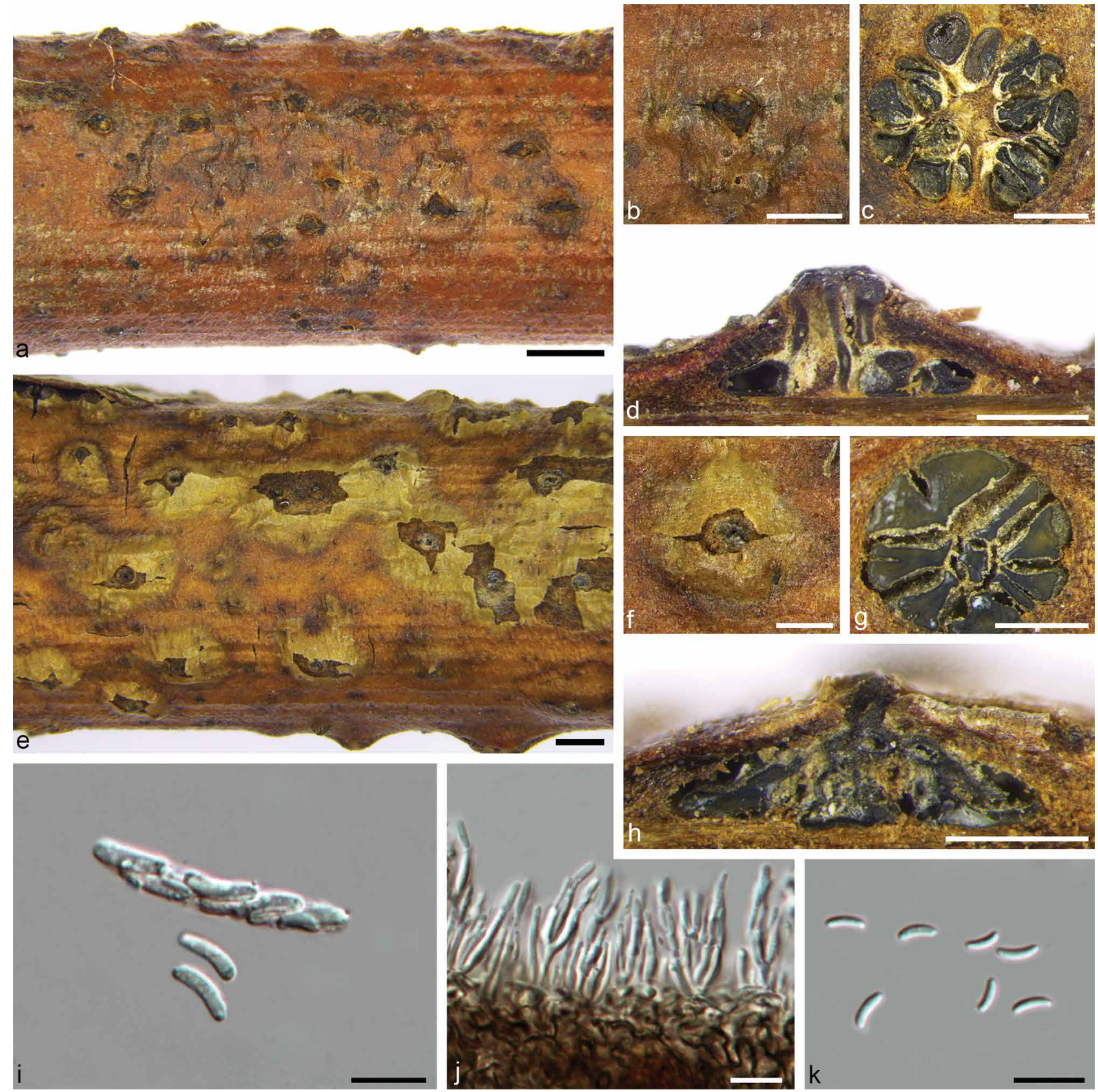

Fig. 41 Cytospora tamaricicola on Tamarix chinensis (CF-2015510). a-b. Habit of ascostromata on branch; c. transverse section through ascostroma; d. longitudinal section through ascostroma; $\mathrm{e}-\mathrm{f}$. habit of conidiomata on branch; g. transverse section through conidioma; h. longitudinal section through conidioma; i. ascus and ascospores; j. conidiogenous cells with attached conidia; $k$. conidia. - Scale bars: $a, e=1 \mathrm{~mm} ; b-d, f-h=0.5 \mathrm{~mm} ; i-k=10 \mu \mathrm{m}$.

Cytospora fugax (Bull.) Fr., Syst. Mycol. (Lundae) 2: 544. 1823

Notes - Cytospora fugax was recorded from stems of $P$ opulus sp. in Inner Mongolia, Jilin and Heilongjiang Provinces, China (Wang et al. 2015). It needs further study to supplement the description.

Cytospora kantschavelii Gvrit., Mikol. Fitopatol. 7: 547. 1973

Notes - Cytospora kantschavelii was reported from stems of Populus sp. in Inner Mongolia and Sichuan Provinces, China (Wang et al. 2015). It needs further study to supplement the illustration and description.

Cytospora palm Q.T. Zhang \& X.Y. Zhang, Cryptog. Mycol. 35: 216. 2014

Notes - Cytospora palm was described and illustrated from twigs of Cotinus coggygria in Beijing, China (Zhang et al. 2014).
Cytospora parasitica Norph., Bulgakov \& K.D. Hyde, Fung. Diversity 75: 146. 2015

Notes - Cytospora parasitica was described from dead branches of Malus sylvestris in Russia (Ariyawansa et al. 2015). Ma et al. (2018) reported that it caused a stem canker disease of apple in the Xinjiang Uygur Autonomous Region, China.

Cytospora trans/ucens Sacc., Syll. Fung. (Abellini) 3: 261. 1884

Notes - Cytospora translucens was recorded based on DNA sequence data from stems of Populus sp. and Salix sp. in Inner Mongolia and Heilongjiang Provinces, China (Wang et al. 2015).

Cytospora tritici Punith., Nova Hedwigia 32: 586. 1980

Notes - Cytospora tritici was recorded as a new pathogen causing canker disease of Populus spp. in Sichuan Province, China (Zhang et al. 2012). 


\section{UNCONFIRMED RECORDS FROM CHINA}

\section{Cytospora curreyi Sacc., Syll. Fung. (Abellini) 3: 269. 1884}

Notes - Cytospora curreyi was recorded from Abies sp. in the Sichuan Province of China (Teng 1963).

\author{
Cytospora microspora Rabenh., Deutschl. Krypt.-FI. (Leipzig) \\ 1: 147.1844
}

Notes - Cytospora microspora was recorded from Quercus sp. in the Hebei Province of China (Teng 1963).

\section{Cytospora personata (Fr.) Sacc., Syll. Fung. (Abellini) 1: 138. 1882}

Basionym. Sphaeria personata Fr., Kongl. Svenska Vetensk.-Akad. Handl. (Ser. 3) 40: 105. 1819.

Synonym. Valsa subclypeata Cooke \& Peck, Ann. Rep. N.Y. State Mus. Nat. Hist. 27: 109. 1875.

Notes - Cytospora personata was recorded from Betula spp. and Rhododendron sp. in the Hebei Province and Northwest China (Teng 1963, Zhuang 2005).

Cytospora rhodophila Sacc., Syll. Fung. (Abellini) 3: 253. 1884

Notes - Cytospora rhodophila was recorded from Rosa sp. in China (Teng 1963, Zhuang 2005).

Cytospora sacchari E.J. Butler, Mem. Dept. Agric. India, Bot. Ser. 1: 31.1906

Notes - Cytospora sacchari was recorded from Saccharum sp. in the Guangdong, Guangxi and Yunan Provinces of China (Teng 1963).

\section{DISCUSSION}

The taxa investigated in the present study represent the largest number of Cytospora strains and species in China ever subjected to DNA sequence analyses. Phylogenetic studies published on the genus Cytospora based on ITS rDNA gene data have substantially influenced its taxonomy (Adams et al. 2005). In the past five years, the polyphasic approach (morphological identification and phylogenetic species recognition concept) has led to the description of several additional new species of Cytospora (Wang et al. 2013, Zhang et al. 2014, Fan et al. 2014a, b, 2015a, b, Yang et al. 2015, Lawrence et al. 2017, 2018, Norphanphoun et al. 2017). In this paper, we summarised 52 Cytospora species reported from China (including seven species in recent studies and five uncertain species). The current study recognised 40 Cytospora species from 88 isolates, including 13 new species and one new combination, which were sampled from 28 host genera distributed over 12 provinces in China (Table 1).

As is the case with many phytopathogenic genera of ascomycetous fungi, the most common phylogenetic problem related to Cytospora taxonomy is that the identification of the most important species (e.g., C. chrysosperma, C. leucostoma and C. mali) are only based on the ITS gene without type materials. In the first taxonomic phylogenetic study of Cytospora, Adams et al. (2002) used ITS sequence data to evaluate the phylogenetic significance of three species from fruit trees. In the Dictionary of Fungi, Kirk et al. (2008) recognised about 110 species in Cytospora, although more than 600 species have been described to date (see Index Fungorum (http://www. indexfungorum.org/) and MycoBank (http://www.mycobank. org/)). Previous taxonomists listed six Cytospora species in their list of fungi known from China, although this is based on old nomenclature and local reports (Teng 1963, Tai 1979, Zhuang
2005). We therefore regard these taxa as dubious, pending their re-examination. Few lists of Cytospora based on living cultures and authentic specimens are available for China. A significant result of the present study was thus to significantly increase the knowledge about Cytospora spp. in China based on DNA analyses of numerous additional isolates, as well as to extend the criteria of identification and number of genes used in Cytospora phylogenetic studies.

Most of the isolates obtained from branches and twigs of $P O-$ pulus and Salix stems displaying symptoms of canker disease were identified as Cytospora chrysosperma in this study. Cytospora chrysosperma is regarded as the most important causal agent of canker disease from Salicaceae with quarantine significance throughout China. This species was first described in Europe by Fries (1823), causing canker disease of Populus sp. Thereafter, this fungal pathogen has been reported on various plant hosts with worldwide distribution, including Fraxinus, Prunus, Triticum, Ulmus and, remarkably, even Homo sapiens (Kalkanci et al. 2006). Past taxonomic studies concluded that many species of Cytospora shared the morphology of C. chrysosperma, and thus it should be regarded as a species complex unless their DNA sequences could be obtained to resolve their identification (Adams et al. 2005). Tai (1979) separated different species from Salicaceae in China with various symptoms, but also assumed that they could possibly represent the same species. The current results restricted $C$. chrysosperma to Populus and Salix (Salicaceae). With regard to host associations, species of Cytospora seem to have wide host ranges, whereas they proved to be mostly limited to a single host species in the current study. Phylogenetic studies of Cytospora based on type materials are hampered by a lack of authentic cultures of previously described species, and thus typification studies from original type materials and/or fresh collections are required to ensure a stable and workable taxonomy. A monographic revision based on the type specimens along with phylogenetic analyses to reassess all species in the genus is urgently required.

The ecology, host specificity and pathogenicity of many Cytospora species are poorly known. Only a few important pathogens on apple and poplar are well studied with respect to their biology, infection and populations. Species of Cytospora are known as opportunistic pathogens mainly on woody hosts and some of the species occur on a wide host range (Adams et al. 2005). For example, the important and highly virulent plant pathogen, C. chrysosperma, has been reported on many other hosts in Australia, Asia, Africa, Europe and America (Spielman 1983, 1985, Adams et al. 2005). Most of the earlier Cytospora species identifications was based on morphology, and their host ranges must therefore be re-evaluated with the application of recent molecular data. Although some Cytospora species, such as $C$. chrysosperma and $C$. leucostoma, have been confirmed from a broad host range, extensive sampling of most other Cytospora species and accumulation of molecular data are required to improve our understanding of their host range and distribution.

In the present study, Cytospora spp. were found to occur in the northeast, northwest, north and southwest China, indicating that the cold and dry environments are always favourable for these taxa in China.

In future studies, extensive fresh specimens should be collected to help clarify the species concepts of taxa still lacking multigene DNA sequence data, especially in west China. The difficulty to observe typical sexual structures in many taxa and the overlapping morphological characteristics are common impediments. We hope that the descriptions and molecular data of Cytospora spp. provided in this study will be a resource for plant pathologists, plant quarantine officials and taxonomists 
to aid in the identification of Cytospora species in China and other countries, as well as supplement our knowledge of their biology, ecology and geographic distribution.

Acknowledgements This study was financed by National Key R\&D Program of China (Project No.: 2017YFD0600105) and National Natural Science Foundation of China (Project No.: 31670647).

\section{REFERENCES}

Adams GC, Roux J, Wingfield MJ, et al. 2005. Phylogenetic relationships and morphology of Cytospora species and related teleomorphs (Ascomycota, Diaporthales, Valsaceae) from Eucalyptus. Studies in Mycology 52: 1-144.

Adams GC, Roux J, Wingfield MJ. 2006. Cytospora species (Ascomycota, Diaporthales, Valsaceae), introduced and native pathogens of trees in South Africa. Australasian Plant Pathology 35: 521-548.

Adams GC, Surve-lyer RS, lezzoni AF. 2002. Ribosomal DNA sequence divergence and group I introns within the Leucostoma species L. cinctum, L. persoonii, and L. parapersoonii sp. nov., ascomycetes that cause Cytospora canker of fruit trees. Mycologia 94: 947-967.

Ariyawansa HA, Hyde KD, Jayasiri SC, et al. 2015. Fungal diversity notes 111-252 - taxonomic and phylogenetic contributions to fungal taxa. Fungal Diversity 75 : 27-274.

Barr ME. 1978. The Diaporthales in North America with emphasis on Gnomonia and its segregates. Mycologia Memoir 7: 1-232.

Carbone I, Kohn L. 1999. A method for designing primer sets for speciation studies in filamentous ascomycetes. Mycologia 91: 553-556.

Castlebury LA, Rossman AY, Jaklitsch WJ, et al. 2002. A preliminary overview of the Diaporthales based on large subunit nuclear ribosomal DNA sequences. Mycologia 94: 1017-1031.

Cooke MC. 1885. New British fungi. Grevillea 14: 1-7.

Crous PW, Gams W, Stalpers JA, et al. 2004. MycoBank: an online initiative to launch mycology into the 21st century. Studies in Mycology 50: 19-22.

Crous PW, Schumacher RK, Akulov A, et al. 2019. New and interesting fungi. 2. Fungal Systematics and Evolution 3: 57-134.

Dennis RWG. 1968. British Ascomycetes 2rd edn. Cramer, Vaduz, Liechtenstein.

Dennis RWG. 1978. British Ascomycetes 3rd edn. Cramer, Vaduz, Liechtenstein.

Donk MA. 1964. Nomina conservanda proposita 1. Proposals in fungi. Deuteromycetes. Regnum Vegetabile 34: 7-15.

Du Q, Zhao SF, Wu CL, et al. 2013. Root rot of Chinese jujube (Ziziphus jujuba) caused by Cytospora sacculus in China. Plant Disease 97: 1661.

Ehrenberg CG. 1818. Sylvae mycologicae berolinenses. Formis Theophili Bruschcke. Berlin, Germany.

Fan XL, Bezerra JDP, Tian CM, et al. 2018. Families and genera of diaporthalean fungi associated with canker and dieback of tree hosts. Persoonia 40: 119-134.

Fan XL, Du Z, Liang YM, et al. 2016. Melanconis (Melanconidaceae) associated with Betula spp. in China. Mycological Progress 15: 40.

Fan XL, Hyde KD, Liu M, et al. 2015a. Cytospora species associated with walnut canker disease in China, with description of a new species C. gigalocus. Fungal Biology 119: 310-319.

Fan XL, Hyde KD, Yang Q, et al. 2015b. Cytospora species associated with canker disease of three anti-desertification plants in northwestern China. Phytotaxa 197: 227-244.

Fan XL, Liang YM, Ma R, et al. 2014a. Morphological and phylogenetic studies of Cytospora (Valsaceae, Diaporthales) isolates from Chinese scholar tree, with description of a new species. Mycoscience 55: 252-259.

Fan XL, Tian CM, Yang Q, et al. 2014b. Cytospora from Salix in northern China. Mycotaxon 129: 303-315.

Fotouhifar KB, Hedjaroude GA, Leuchtmann A. 2010. ITS rDNA phylogeny of Iranian strains of Cytospora and associated teleomorphs. Mycologia 102: 1369-1382.

Fries EM. 1823. Systema mycologicum. Vol. 2, Greifswald, Germany.

Fries EM. 1825. Systema orbis vegetabilis. Pars 1. Plantae homonemeae. Typographia Academica, Lund, Sweden.

Gilman JC, Tiffany LH, Lewis RM. 1957. Iowa Ascomycetes II. Diaporthaceae: Valsaceae. lowa State College Journal of Science 31: 623-647.

Glass NL, Donaldson GC. 1995. Development of primer sets designed for use with the PCR to amplify conserved genes from filamentous ascomycetes. Applied and Environmental Microbiology 61: 1323-1330.

Grove WB. 1935. British stem- and leaf-fungi (Coelomycetes) 1. Cambridge University Press, UK.

Gryzenhout M, Myburg H, Wingfield BD, et al. 2006. Cryphonectriaceae (Diaporthales), a new family including Cryphonectria, Chrysoporthe, Endothia and allied genera. Mycologia 98: 239-249.
Guindon S, Dufayard JF, Lefort V, et al. 2010. New algorithms and methods to estimate maximum-likelihood phylogenies: assessing the performance of PhyML 3.0. Systematic Biology 59: 307-321.

Guterres DC, Galvão-Elias S, Santos MDM, et al. 2019. Phylogenetic relationships of Phaeochorella parinarii and recognition of a new family, Phaeochorellaceae (Diaporthales). Mycologia. doi: 10.1080/00275514. 2019.1603025

Gvritishvili MN. 1973. New species of fungi belonging to genus Cytospora Fr. II. Mikologiya i Fitopatologiya 7: 544-549. [In Russian.]

Gvritishvili MN. 1982. The fungal genus Cytospora in the USSR. Izdatelstve Sabchota Sakarstvelo, Tbilici, Russia.

Hayova VP, Minter DW. 1998. Valsa ambiens subsp. ambiens. International Mycological Institute Descriptions of Fungi and Bacteria 1364: 1-4.

Hillis DM, Bull JJ. 1993. An empirical test of bootstrapping as a method for assessing confidence in phylogenetic analysis. Systematic Biology 42: 182-192.

Huang F, Hou X, Dewdney MM, et al. 2013. Diaporthe, species occurring on citrus in China. Fungal Diversity 61: 237-250.

Hyde KD, Hongsanan S, Jeewon R, et al. 2016. Fungal diversity notes 367-490: taxonomic and phylogenetic contributions to fungal taxa. Fungal Diversity 80: 1-270.

Jami F, Marincowitz S, Crous PW, et al. 2018. A new Cytospora species pathogenic on Carpobrotus edulis in its native habitat. Fungal Systematics and Evolution 2: 37-43.

Kalkanci A, Kustimur S, Sucak GT, et al. 2006. Fulminating fungal sinusitis caused by Valsa sordida, a plant pathogen, in a patient immunocompromised by acute myeloid leukemia. Medical Mycology 44: 531-539.

Katoh K, Standley DM. 2013. MAFFT multiple sequence alignment software version 7: improvements in performance and usability. Molecular Biology and Evolution 30: 772-780.

Kirk PM, Canoon PF, Minter DW, et al. 2008. Ainsworth \& Bisby's dictionary of the fungi, 10rd edn, Wallingford, UK.

Kobayashi T. 1970. Taxonomic studies of Japanese Diaporthaceae with special reference to their life-histories. Tokyo, Japan.

Lawrence DP, Holland LA, Nouri MT, et al. 2018. Molecular phylogeny of Cytospora species associated with canker diseases of fruit and nut crops in California, with the descriptions of ten new species and one new combination. IMA Fungus 9: 333-370.

Lawrence DP, Travadon R, Pouzoulet J, et al. 2017. Characterization of Cytospora isolates from wood cankers of declining grapevine in North America, with the descriptions of two new Cytospora species. Plant Pathology 66: 713-725.

Liu JK, Hyde KD, Jones EG, et al. 2015. Fungal diversity notes 1-110: taxonomic and phylogenetic contributions to fungal species. Fungal Diversity 72: 1-197.

Liu YJ, Whelen S, Hall BD. 1999. Phylogenetic relationships among ascomycetes: Evidence from an RNA polymerse II subunit. Molecular Biology and Evolution 16: 1799-1808.

Ma R, Liu YM, Yin YX, et al. 2018. A canker disease of apple caused by Cytospora parasitica recorded in China. Forest Pathology 48: e12416.

Mehrabi ME, Mohammadi GE, Fotouhifar KB. 2011. Studies on Cytospora canker disease of apple trees in Semirom region of Iran. Journal of Agricultural Technology 7: 967-982.

Mulenko W, Majewski T, Ruszkiewicz-Michalska M. 2008. A preliminary checklist of micromycetes in Poland. Polish Academy of Sciences, Poland.

Nannfeldt JA. 1932. Studien über die Morphologie und Systematik der nichtlichenisierten inoperculaten Discomyceten. Nova Acta Regiae Societas Scientiarum Upsaliensis 48: 1-368.

Nitschke T. 1867. Pyrenomycetes Germanici. Wrocław, Poland.

Norphanphoun C, Doilom M, Daranagama DA, et al. 2017. Revisiting the genus Cytospora and allied species. Mycosphere 8: 51-97.

Norphanphoun C, Raspé O, Jeewon R, et al. 2018. Morphological and phylogenetic characterisation of novel Cytospora species associated with mangroves. Mycokeys 38: 93-120.

Palavouzis SC, Tzamos S, Paplomatas E, et al. 2015. First report of Cytospora punicae isolated from pomegranate plants with symptom of collar rot in northern Greece. Journal of Plant Pathology 97: 209-220.

Posada D, Crandall KA. 1998. Modeltest: testing the model of DNA substitution. Bioinformatics 14: 817-818.

Rambaut A, Drummond A. 2010. FigTree v.1.3.1. Institute of Evolutionary Biology, University of Edinburgh, Edinburgh, UK.

Rannala B, Yang Z. 1996. Probability distribution of molecular evolutionary trees: a new method of phylogenetic inference. Journal of Molecular Evolution 43: 304-311.

Rayner RW. 1970. A mycological colour chart. Commonwealth Mycological Institute, Kew, UK.

Ronquist F, Huelsenbeck JP. 2003. MrBayes 3: Bayesian phylogenetic inference under mixed models. Bioinformatics 19: 1572-1574. 
Rossman AY, Adams GC, Cannon PF, et al. 2015. Recommendations of generic names in Diaporthales competing for protection or use. IMA Fungus 6: 145-154.

Rossman AY, Farr DF, Castlebury LA. 2007. A review of the phylogeny and biology of the Diaporthales. Mycoscience 48: 135-144.

Saccardo PA. 1879. Michelia 1. Typis Seminarii, Italy.

Saccardo PA. 1881. Michelia 2. Typis Seminarii, Italy.

Saccardo PA. 1884. Sylloge fungorum 3, Typis Seminarii, Italy.

Saccardo PA. 1892. Sylloge fungorum 10, Typis Seminarii, Berlin, Germany.

Senanayake IC, Crous PW, Groenewald JZ, et al. 2017. Families of Diaporthales based on morphological and phylogenetic evidence. Studies in Mycology 86: 217-296.

Senanayake IC, Jeewon R, Chomnunti P, et al. 2018. Taxonomic circumscription of Diaporthales based on multigene phylogeny and morphology. Fungal Diversity 93: 241-443.

Spielman LJ. 1983. Taxonomy and biology of Valsa species on hardwoods in North America, with special reference to species on maples. Cornell University, New York, USA.

Spielman LJ. 1985. A monograph of Valsa on hardwoods in North America. Canadian Journal of Botany 63: 1355-1378.

Swofford DL. 2003. PAUP*: Phylogenetic Analysis Using Parsimony (*and other methods) version 4.0b10. Sinauer Associates, Sunderland.

Sydow H, Sydow P. 1904. Mycotheca germanica fasc. III. Annales Mycologici 2: 190-192.

Sydow P. 1897. Beiträge zur Kenntnis der Pilzflora der Mark Brandenburg. I. Hedwigia Beiblatt 36: 157-164.

Tai FL. 1979. Sylloge fungorum sinicorum, Beijing, China. Beijing, Science Press, Academia Sinica.

Tamura K, Stecher G, Peterson D, et al. 2013. MEGA6: Molecular Evolutionary Genetics Analysis version 6.0. Molecular Biology and Evolution 30: 2725-2729.

Teng SC. 1963. Fungi of China, Beijing, China. Beijing, Science Press. [In Chinese.]

Teng SC. 1996. Fungi of China. Ithaca, Mycotaxon, Ltd., NY, USA.

Urban Z. 1957. Vorlaufige mitteilung der ergebnisse einer revision der gattungen Valsa und Valsella. Preslia 29: 394-395.

Vilgalys R, Hester M. 1990. Rapid genetic identification and mapping of enzymatically amplified ribosomal DNA from several Cryptococcus species. Journal of Bacteriology 172: 4238-4246.
Voglmayr H, Rossman AY, Castlebury LA, et al. 2012. Multigene phylogeny and taxonomy of the genus Melanconiella (Diaporthales). Fungal Diversity 57: $1-44$.

Von Höhnel F. 1918. Mykologische fragmente. Annales Mycologici 16: 35-174. Wang XL, Kang ZS, Huang LL, et al. 2007. Pathogen identification of Valsa canker on pear tree: evidences from rDNA-ITS sequences and cultural characteristics. Mycosystema 26: 517-527.

Wang XL, Kang ZS, Huang LL, et al. 2011. Re-evaluation of pathogens causing Valsa canker on apple in China. Mycologia 103: 317-324.

Wang YL, Lu Q, Decock C, et al. 2015. Cytospora species from Populus and Salix in China with C. davidiana, sp. nov. Fungal Biology 119: 420-432.

Wang YL, Lu Q, Jia XZ, et al. 2013. First report of branch canker caused by Cytospora atrocirrhata on Populus sp. and Salix sp. in China. Plant Disease 97: 426.

Wehmeyer LE. 1975. The pyrenomycetous fungi. Mycologia Memoirs 6: $1-$ 250.

Wei JC. 1979. Identification of fungus handbook, Shanghai, China. Shanghai, Shanghai Science and Technology Press.

White TJ, Bruns T, Lee S, et al. 1990. Amplification and direct sequencing of fungal ribosomal RNA genes for phylogenetics. PCR protocols: A guide to methods and applications 18: 315-322.

Wingfield MJ, Beer ZWD, Slippers B, et al. 2012. One fungus, one name promotes progressive plant pathology. Molecular Plant Pathology 13: 604-613.

Xavier KV, Nepal Kc A, Crous PW, et al. 2019. Dwiroopa punicae sp. nov. (Dwiroopaceae fam. nov., Diaporthales), associated with leaf spot and fruit rot of pomegranate (Punica granatum). Fungal Systematics and Evolution 4: 33-41.

Yang Q, Fan XL, Crous PW, et al. 2015. Cytospora from Ulmus pumila in Northern China. Mycological Progress 14: 74.

Zhang QT, He M, Zhang XY, et al. 2012. Canker on bark of Populus spp. caused by Cytospora tritici, a new disease in China. Plant Disease 96: 1578.

Zhang YB, You CJ, Fan XL, et al. 2014. Taxonomy and phylogeny of Cytospora in Northeast China. Mycosystema 33: 806-818.

Zhao GC, Sheng SF, Li N. 1991. A new species of Valsa. Journal of Northeast Forestry University 2: 105-107.

Zhu HY, Tian CM, Fan XL. 2018. Multigene phylogeny and morphology reveal Cytospora spiraeae sp. nov. (Diaporthales, Ascomycota) in China. Phytotaxa 338: 49-62.

Zhuang WY. 2005. Fungi of Northwestern China, New York, USA. Ithaca, Mycotaxon, Ltd. 